\title{
International Union of Basic and Clinical Pharmacology. LXXV. Nomenclature, Classification, and Pharmacology of G Protein-Coupled Melatonin Receptors
}

\begin{abstract}
Margarita L. Dubocovich, Philippe Delagrange, Diana N. Krause, David Sugden, Daniel P. Cardinali, and James Olcese
Department of Pharmacology and Toxicology, School of Medicine and Biomedical Sciences, University at Buffalo, State University of New York, Buffalo, New York (M.L.D.); Department Molecular Pharmacology and Biological Chemistry, Feinberg School of Medicine, Northwestern University, Chicago, Illinois (M.L.D.); Experimental Sciences Department, Institut de Recherches Servier, Suresnes, France (P.D.); Department of Pharmacology, College of Medicine, University of California, Irvine, California (D.N.K.); Division of Reproduction and Endocrinology, School of Biomedical and Health Sciences, King's College London, United Kingdom (D.S.); Department of Teaching \& Research, Faculty of Medical Sciences, Pontificia Universidad Católica Argentina, Buenos Aires, Argentina (D.P.C.); and Department of Biomedical Sciences, Florida State University College of Medicine, Tallahassee, Florida (J.O.)
\end{abstract}

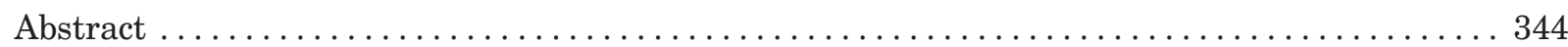

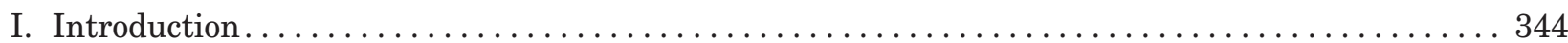

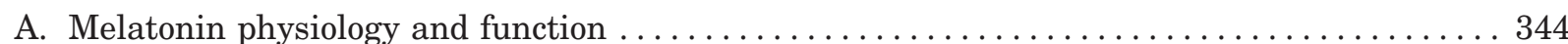

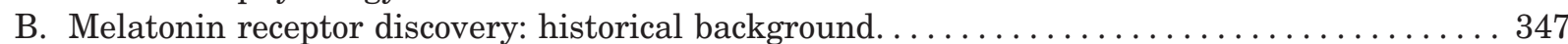

C. International Union of Basic and Clinical Pharmacology criteria for receptor nomenclature and drug classification . . . . . . . . . . . . . . . . . . . . . . . . . 348

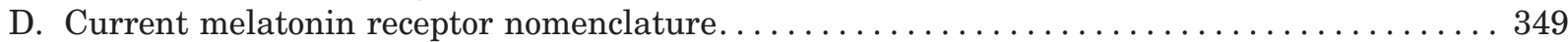

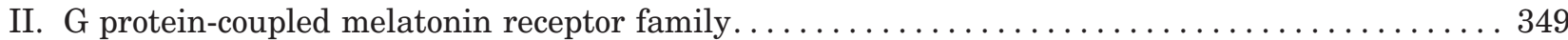

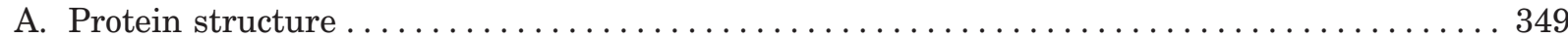

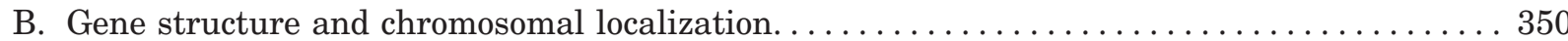

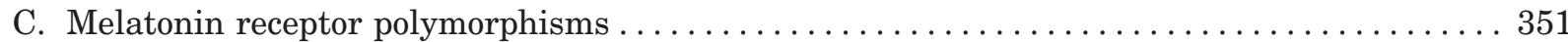

D. Molecular structure of $\mathrm{MT}_{1}$ and $\mathrm{MT}_{2}$ melatonin receptor ligand binding pockets $\ldots \ldots \ldots 352$

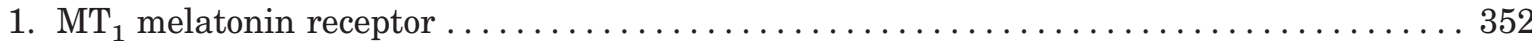

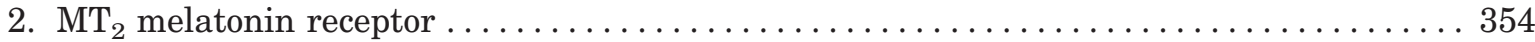

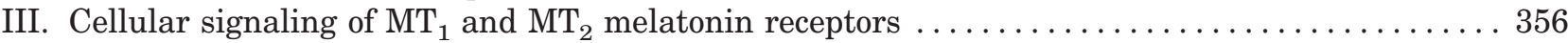

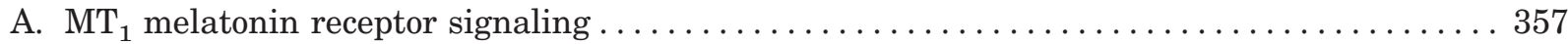

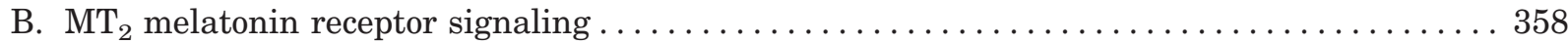

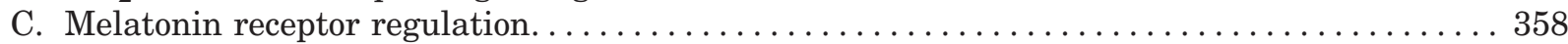

IV. $\mathrm{MT}_{1}$ and $\mathrm{MT}_{2}$ melatonin receptors: structure-activity relationships and selective ligands. . . . 359

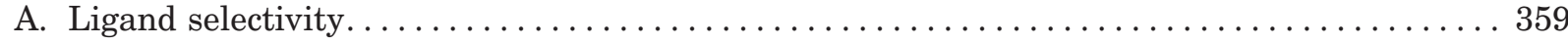

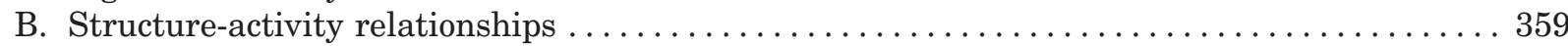

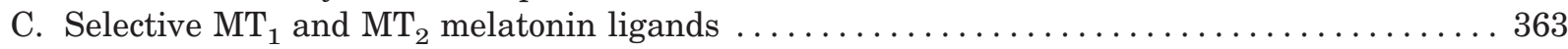

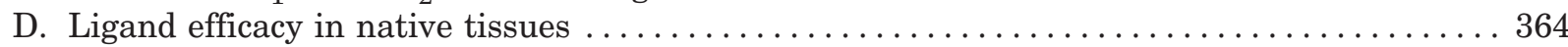

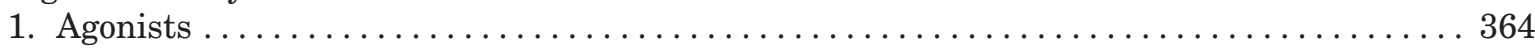

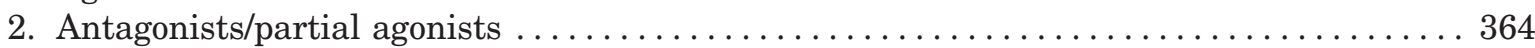

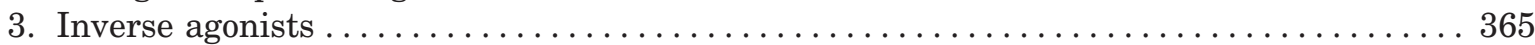

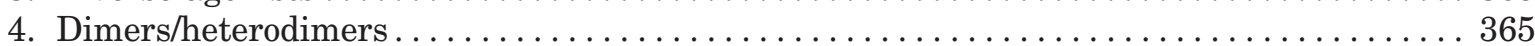

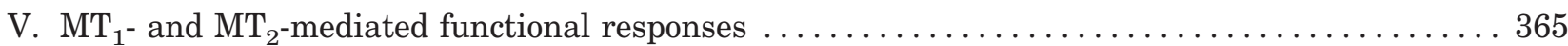

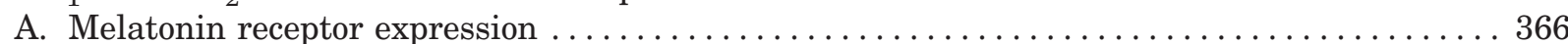

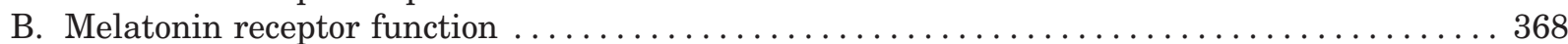

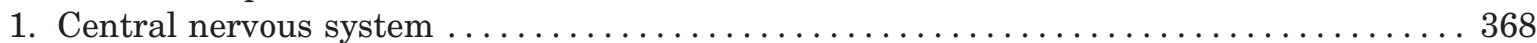

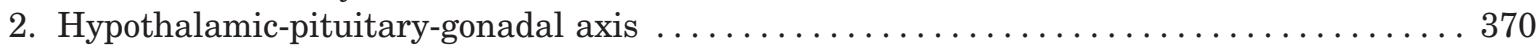

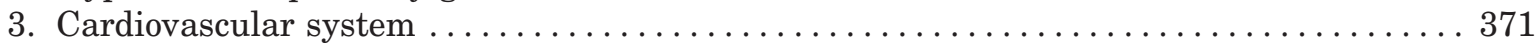

Address correspondence to: Dr. Margarita L. Dubocovich, Department of Pharmacology and Toxicology, 102 Farber Hall, School of Medicine and Biomedical Sciences University at Buffalo State University of New York (SUNY), 3435 Main Street, Buffalo, NY 14214. E-mail: mdubo@buffalo.edu

This article is available online at http://pharmrev.aspetjournals.org.

doi:10.1124/pr.110.002832. 


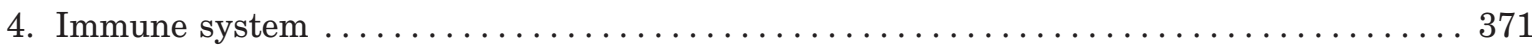

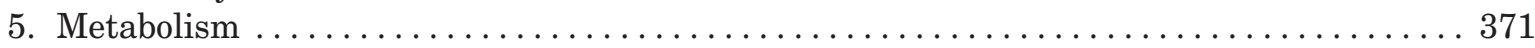

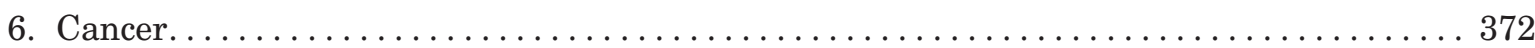

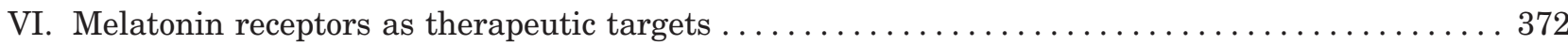

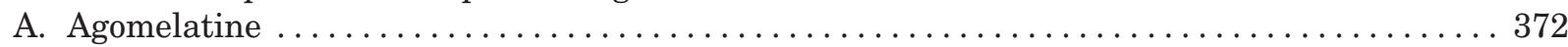

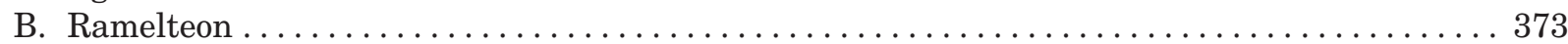

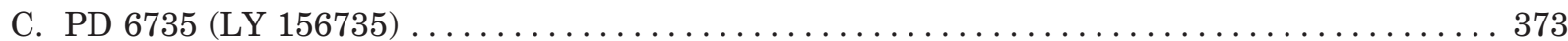

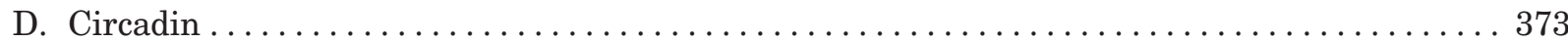

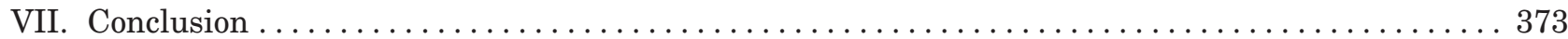

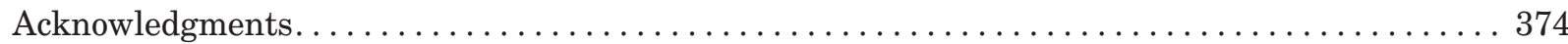

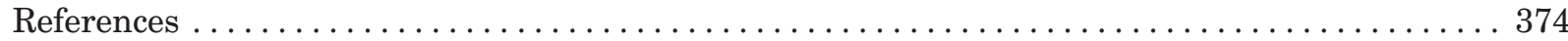

\begin{abstract}
The hormone melatonin (5-methoxy- $N$ acetyltryptamine) is synthesized primarily in the pineal gland and retina, and in several peripheral tissues and organs. In the circulation, the concentration of melatonin follows a circadian rhythm, with high levels at night providing timing cues to target tissues endowed with melatonin receptors. Melatonin receptors receive and translate melatonin's message to influence daily and seasonal rhythms of physiology and behavior. The melatonin message is translated through activation of two $G$ protein-coupled receptors, $\mathrm{MT}_{1}$ and $\mathrm{MT}_{2}$, that are potential therapeutic
\end{abstract}

targets in disorders ranging from insomnia and circadian sleep disorders to depression, cardiovascular diseases, and cancer. This review summarizes the steps taken since melatonin's discovery by Aaron Lerner in 1958 to functionally characterize, clone, and localize receptors in mammalian tissues. The pharmacological and molecular properties of the receptors are described as well as current efforts to discover and develop ligands for treatment of a number of illnesses, including sleep disorders, depression, and cancer.

\section{Introduction}

Melatonin (5-methoxy- $N$-acetyltryptamine) is an important hormonal output of the circadian system, and it circulates nightly to provide timing cues to any tissue that can read the message. Melatonin receptors, of course, are the entities that receive and translate this message to influence daily and seasonal rhythms of physiology and behavior. Our evolving understanding of melatonin receptors is providing new insights into where and how this hormone exerts its physiological effects in the body as well as how these receptors may be useful therapeutic targets in disorders ranging from insomnia and jet lag to depression, cancer, and cardiovascular disease.

The field of mammalian melatonin receptors got off to a slow start; the first pharmacological characterization of a functional mammalian melatonin receptor (Dubocovich, 1983) and the cloning of the first human melatonin receptor (Reppert et al., 1994) came 25 and 36 years, respectively, after melatonin itself was discovered (Lerner et al., 1959). Now, however, the field is moving quickly, and there are sufficient data upon which to organize and classify the known mammalian melatonin receptors. That topic is the focus of this review.

\section{A. Melatonin Physiology and Function}

In mammals, melatonin is secreted primarily by the pineal gland during the dark period of the daily light/ dark cycle (for reviews, see Cardinali, 1981; Reiter, 1991; Borjigin et al., 1999; Klein, 1999; Olcese, 1999).
The circadian rhythm of pineal melatonin synthesis and release is driven by circadian pacemaker cells (the "master clock") located in the suprachiasmatic nucleus $\left(\mathrm{SCN}^{1}\right)$ of the hypothalamus that project to the pineal via a multisynaptic pathway (Fig. 1). Melatonin is also synthesized in the retina and a clock mechanism within the retina itself seems to drive the melatonin rhythm in this tissue (Tosini and Menaker, 1998; Tosini et al., 2007). In both cases, the clock rhythm is entrained to a 24-h period by environmental light (the photoperiod) that is sensed by a subset of retinal ganglion cells containing the photopigment melanopsin, which conveys photic stimuli to the SCN via the retinohypothalamic tract (Berson et al., 2002).

The melatonin rhythm is a consequence of the regulation of the hormone's synthetic enzymes, which are highly active at night (see Fig. 2). Melatonin is synthesized from serotonin through two enzymatic steps. First,

\footnotetext{
${ }^{1}$ Abbreviations: 4P-ADOT, 4-phenyl-2-acetamidotetraline; 4PPDOT, 4-phenyl-2-propionamidotetraline; 5-HEAT, 5-hydroxyethoxy- $N$-acetyltryptamine; AA-NAT, arylalkylamine $N$-acetyltransferase; AFMK, $N^{1}$-acetyl- $N^{2}$-formyl-5-methoxykynuramine; AMK, $N^{1}$-acetyl-5-methoxykynuramine; AMMTC, $N$-acetyl-4aminomethyl-6-methoxy-9-methyl-1,2,3,4-tetrahydrocarbazole; $\mathrm{BK}_{\mathrm{Ca}}$, calcium-activated potassium channel; $\mathrm{CHO}$, Chinese hamster ovary; CREB, cAMP responsive element binding protein; CT, circadian time; GLP-1, glucagon-like peptide; GPCR, G proteincoupled receptor; H-89, 5-isoquinolinesulfonamide; HIOMT, hydroxyindole- $O$-methyltransferase; $\mathrm{KO}$, knockout; $\mathrm{PKC}$, protein kinase C; PTX, pertussis toxin; RT-PCR, reverse transcriptionpolymerase chain reaction; SCN, suprachiasmatic nucleus; TM, transmembrane; WT, wild type.
} 


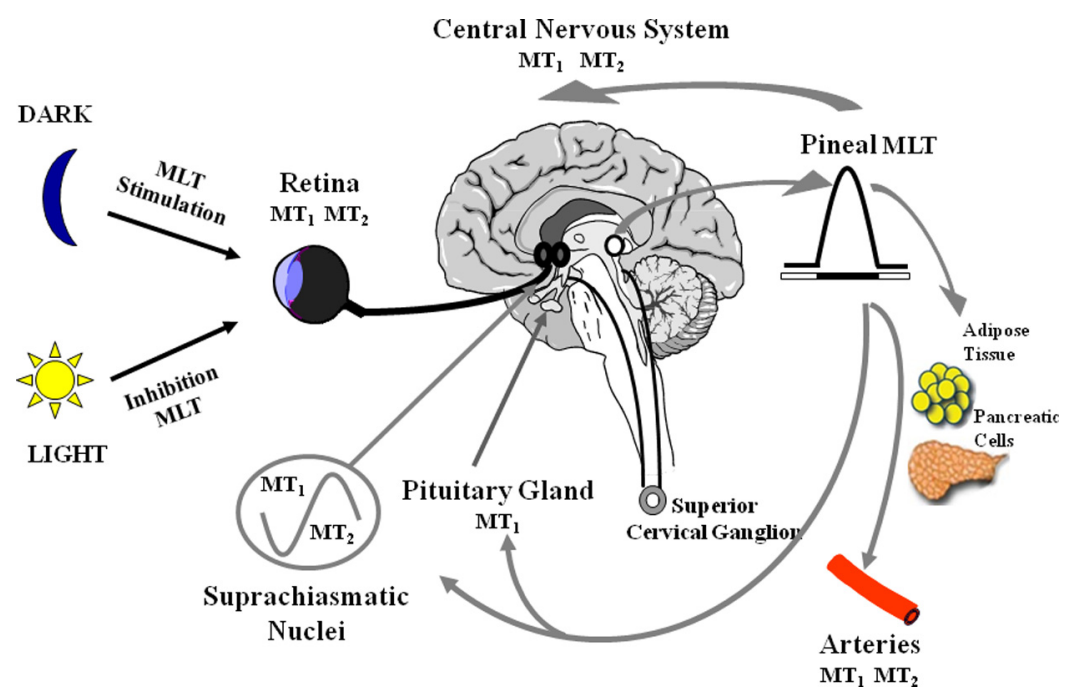

FIG. 1. Regulation of melatonin production and receptor function. Melatonin is synthesized in the pineal gland and in the retina. In the pineal gland, melatonin (MLT) synthesis follows a rhythm driven by the suprachiasmatic nucleus, the master biological clock. Neural signals from the SCN follow a multisynaptic pathway to the superior cervical ganglia. Norepinephrine released from postganglionic fibers activates $\alpha_{1}$-and $\beta_{1}$-adrenoceptors in the pinealocyte, leading to increases in second messengers (i.e., cAMP and inositol trisphosphate) and the activity of AA-NAT, the rate-limiting step in melatonin synthesis. The system is dramatically inhibited by light, the external cue that allows entrainment to the environmental light/dark cycle. The photic signal received by the retina is transmitted to the SCN via the retinohypothalamic tract, which originates in a subset of retinal ganglion cells. Pineal melatonin thus serves as the internal signal that relays day length, allowing regulation of neuronal activity $\left(\mathrm{MT}_{1}\right)$ and circadian rhythms $\left(\mathrm{MT}_{1}, \mathrm{MT}_{2}\right.$ ) in the SCN (Dubocovich, 2007), of neurochemical function in brain through the $\mathrm{MT}_{1}$ and $\mathrm{MT}_{2}$ receptors (Dubocovich, 2006), of vascular tone through activation of $\mathrm{MT}_{1}$ (constriction) and $\mathrm{MT}_{2}$ receptors (dilation) in arterial beds (Masana et al., 2002), and seasonal changes in reproductive physiology and behavior through activation of $\mathrm{MT}_{1}$ receptors in the pars tuberalis (Duncan, 2007). The pars tuberalis of the pituitary gland interprets this rhythmic melatonin signal and generates a precise cycle of expression of circadian genes through activation of $\mathrm{MT}_{1}$ receptors. Melatonin synthesis in the photoreceptors of the retina follows a similar circadian rhythm generated by local oscillators (Tosini et al., 2007). Activation of $\mathrm{MT}_{1}$ and $\mathrm{MT}_{2}$ melatonin receptors regulate retina function and hence transmission of photic information to the brain (Dubocovich et al., 1997). [Adapted from Dubocovich ML and Masana M (2003) Melatonin receptor signaling, in Encyclopedia of Hormones and Related Cell Regulators (Henry H and Norman A eds), pp 638-644, Academic Press, San Diego, CA. Copyright (C) 2003 Academic Press. Used with permission.]

serotonin $N$-acetyltransferase [arylalkylamine $N$-acetyltransferase (AA-NAT)] acetylates serotonin to yield $N$ acetylserotonin. The second step involves transfer of a methyl group from $(S)$-adenosylmethionine to the 5-hydroxy group of $N$-acetylserotonin via the enzyme hydroxyindole-O-methyltransferase (HIOMT). The regulation of these enzymes is fascinating and much studied (Wurtman and Axelrod, 1968; Cardinali, 1981; Klein, 1999, 2007; Olcese, 1999). Most recently, molecular approaches are revealing the transcriptional and posttranscriptional mechanisms responsible for daily fluctuations in AA-NAT (Borjigin et al., 1995, 1999; Roseboom et al., 1996; Gastel et al., 1998; Klein, 1999; Fukuhara et al., 2001) and regulation of HIOMT (Gauer and Craft, 1996). Use of sensitive RT-PCR techniques suggests that low levels of AA-NAT and HIOMT, and therefore local melatonin synthesis, may also occur in other tissues, such as gut, testis, spinal cord, raphe nucleus, and striatum (Stefulj et al., 2001). In mammals, most of the nocturnal rhythm in circulating melatonin is abolished by pinealectomy (Simonneaux and Ribelayga, 2003). However, sporadic reports suggested that as much as $20 \%$ of circulating melatonin is derived from tissues other than the pineal gland (Ozaki and Lynch, 1976).

The lipophilicity of the melatonin molecule allows it to diffuse passively across cell membranes as well as cell layers, and thus it can diffuse from the pinealocytes as soon as it is synthesized. Early studies by
Cardinali et al. (1972) showed melatonin binding to human plasma albumin. This observation was later confirmed by Pardridge and Mietus (1980). These authors also reported that albumin-bound melatonin crosses the blood-brain barrier. Melatonin binding to plasma albumin was confirmed by Morin et al. (1997) and provided evidence of high-affinity melatonin binding to $\alpha 1$-acid glycoprotein (Cardinali et al., 1972; Morin et al., 1997). An excellent correlation was demonstrated between saliva melatonin in humans and levels of unbound serum melatonin, suggesting for the first time that melatonin binding to plasma proteins may affect the levels of free melatonin and hence physiological responses (Kennaway and Voultsios, 1998). Because the levels of albumin and $\alpha 1$-acid glycoprotein may vary with age and disease, particularly during inflammatory processes, the level of free melatonin and drugs in human plasma cannot be predicted and has to be considered on a case-by-case basis (Viani et al., 1992; Morin et al., 1997; Waldhauser et al., 1988).

Melatonin rapidly disappears from the blood, with a half-life of approximately $30 \mathrm{~min}$, depending on the species examined (Cardinali et al., 1972; Waldhauser et al., 1984). In humans, most melatonin in the general circulation is converted to 6 -hydroxymelatonin by the liver, which clears 92 to $97 \%$ of circulating melatonin in a single pass (Tetsuo et al., 1980; Young et al., 1985). Then 6-hydroxymelatonin 


\section{MELATONIN SYNTHESIS}

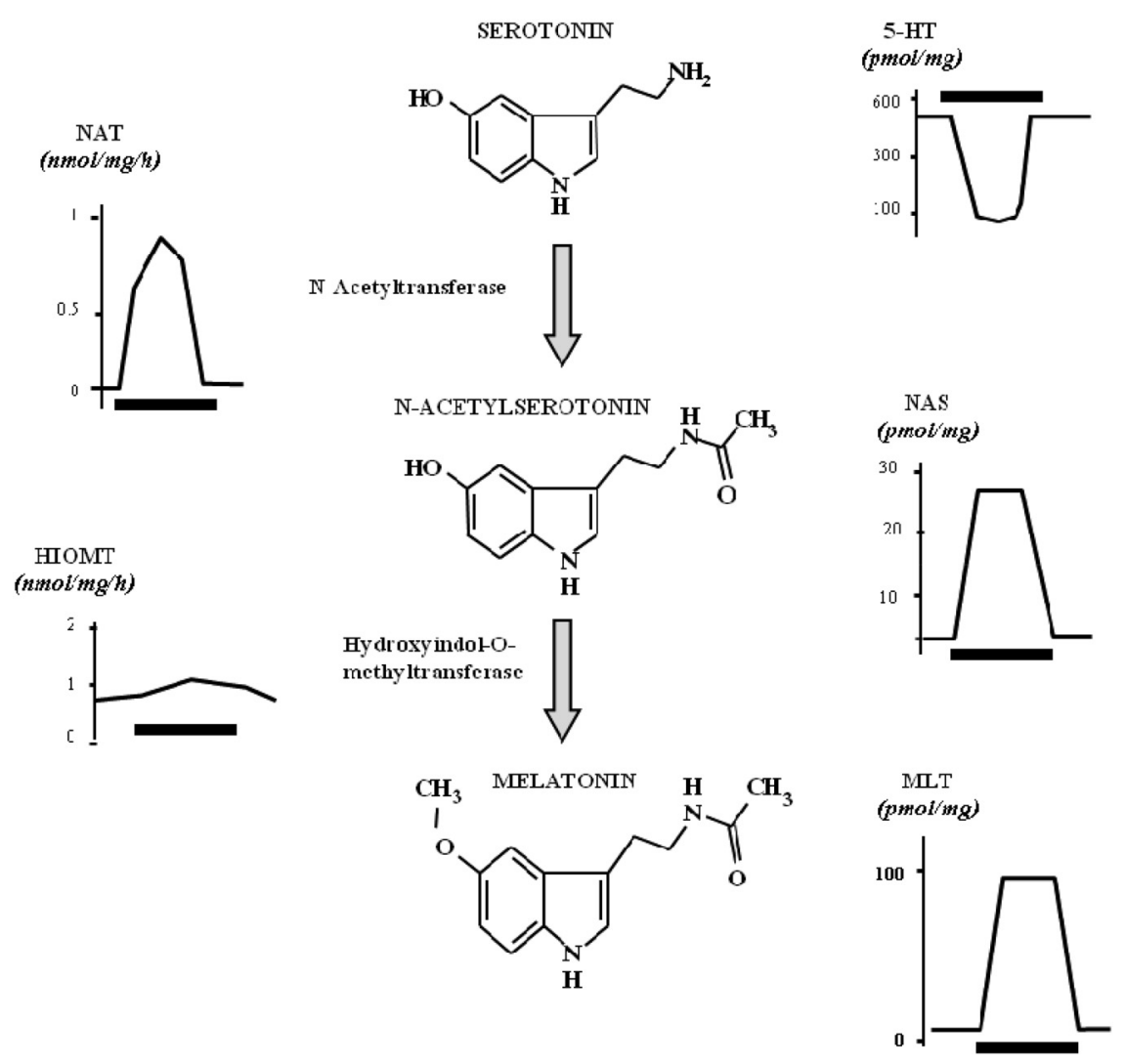

Fig. 2. Melatonin synthesis. Melatonin (MLT) is synthesized from serotonin through two enzymatic steps. First, serotonin is acetylated by NAT to yield $N$-acetylserotonin (NAS). The second step involves transfer of a methyl group from $(S)$-adenosylmethionine to the 5-hydroxyl group of $N$-acetylserotonin via the enzyme HIOMT. The rhythms of melatonin and serotonin have opposite phase during subjective night and day (Klein, 1999).

is conjugated and excreted into the urine, approximately 50 to $80 \%$ as the sulfate derivative and 5 to $30 \%$ as the glucuronide (Ma et al., 2008). It is important to point out that the most abundant metabolite in mouse urine is 6-hydroxymelatonin excreted as the glucuronide conjugate (7588\%) (Kennaway et al., 2002; Ma et al., 2008). Melatonin metabolism in the brain, however, may involve oxidative pyrrole-ring cleavage. No 6-hydroxymelatonin is detected after melatonin injection into the cisterna magna (Hirata et al., 1974). This pathway may be particularly important because melatonin is also released via the pineal recess into the cerebrospinal fluid as well as into the circulation (Tricoire et al., 2002). The primary cleavage product is $N^{1}$-acetyl- $N^{2}$-formyl-5-methoxykynuramine (AFMK), which is deformylated, either by arylamine formamidase or hemoperoxidases, to $N^{1}$-acetyl-5-methoxykynuramine (AMK). Surprisingly, numerous enzymatic (indoleamine 2,3-dioxygenase, myeloperoxidase), pseudoenzymatic (oxoferryl hemoglobin, hemin), photocatalytic, or free-radical reactions lead to the same product: AFMK (Hardeland 2005). Some estimates indicate that pyrrole ring cleavage contributes to approximately one third of the total catabolism of melatonin (Ferry et al., 2005), but the percentage may be even higher in certain tissues. Other oxidative catabolites are cyclic 3-hydroxymelatonin, which can also be metabolized to AFMK, and a 2-hydroxylated analog that does not cyclize but turns into an indolinone (Hardeland 2005). Additional hydroxylated or nitrosated metabolites have been detected, but they seem to be present in minor quantities only. AFMK and AMK also form metabolites by interactions with reactive oxygen and nitrogen species (Tan et al., 2007). Antioxidative protection, safeguarding of mitochondrial electron flux, and, in particular, neuroprotection have been demonstrated in many experimental systems to be mediated by melatonin and its endogenous metabolites. This effect is not mediated by the known G protein-coupled melatonin receptors and thus will not be reviewed in this article.

The melatonin metabolites produced in the liver (e.g., 6-hydroxymelatonin) and in the brain (e.g., AFMK and AMK) are known to modulate a variety of functional responses possible through activation of the G-proteincoupled melatonin receptor. 6-Hydroxymelatonin competed for $2-\left[{ }^{125} \mathrm{I}\right]$ iodomelatonin binding to both the $\mathrm{MT}_{1}$ and $\mathrm{MT}_{2}$ melatonin receptors (Dubocovich et al., 1997). This metabolite also decreases in a concentration dependent manner the calcium dependent release of $\left[{ }^{3} \mathrm{H}\right]$ dopamine from rabbit retina (Dubocovich, 1985). AFMK and 
AMK decrease sexual development in a prepubertal rat model (Kennaway et al., 1988). It is noteworthy that AFMK accelerates re-entrainment of the 6-hydroxymelatonin rhythm, when given at the new dark onset, after a phase advance of the light/dark cycle in male rats (Kennaway et al., 1989).

The melatonin rhythm is an important efferent hormonal signal driven by the endogenous clock, which can therefore be used as an internal synchronizer (or "internal Zeitgeber") (Dawson and Armstrong, 1996). Melatonin can impose circadian rhythmicity upon target structures, and it also is known to act directly on the SCN to modulate the clock itself. Exogenous melatonin, given at the same time of day, can entrain physiological and behavioral rhythms (e.g., body temperature and rest-activity cycles) (Arendt and Skene, 2005). Melatonin has been reported to modulate a myriad of other functions, including visual, neuroendocrine, reproductive, neuroimmune, and vascular physiology (Arendt, 2000; Cagnacci et al., 2000; Castrillón et al., 2000; Monti and Cardinali, 2000; Maestroni, 2001; Sharkey et al., 2009). Because the duration of nocturnal melatonin secretion is directly proportional to the length of the night, this hormone also provides a signal for seasonal change. Melatonin is, indeed, the critical parameter for photoperiod integration and the induction of particular physiological responses, such as those observed in seasonal breeders (Karsch et al., 1988; Pitrosky et al., 1991; Cardinali and Pévet, 1998; Malpaux et al., 1999).

In addition to the circadian rhythm of the endogenous ligand, target tissues and physiological responses can also display daily variations in receptivity to melatonin. For example, optimal entrainment of the activity rhythm in rodents housed in constant darkness occurs when melatonin is administered at the onset of activity; this induces a phase advance in the animal's rhythm (Cardinali et al., 1997; Redman, 1997). It is possible that melatonin transmits photoperiodic information by regulating its own receptors, perhaps by altering receptor density, transduction mechanisms, and/or trafficking (Tenn and Niles, 1993; Gerdin et al., 2004a,b). Further discussion in this area is beyond this review, because it focuses primarily on the action of exogenous melatonin and drugs with therapeutic potential mediating actions through activation of $\mathrm{MT}_{1}$ and/or $\mathrm{MT}_{2}$ melatonin receptors.

\section{B. Melatonin Receptor Discovery: Historical Background}

The study of melatonin receptors can be traced back to 1917, when McCord and Allen demonstrated lightening of Rana pipiens tadpole skin by bovine pineal extracts. This bioassay was used to isolate melatonin from pineal extracts, which led to the elucidation of its chemical structure (Lerner et al., 1959). The action of melatonin to aggregate pigment granules (melanosomes) of amphibian dermal melanophores was used to 1) postulate the presence of melatonin receptors (Heward and Hadley, 1975); 2) establish the first structure-activity rela- tionships of melatonin analogs (Heward and Hadley, 1975); and 3) demonstrate that melatonin receptors are coupled to a pertussis toxin-sensitive G-protein (White et al., 1987). It is noteworthy that the first melatonin receptor $\left(\mathrm{Mel}_{1 \mathrm{c}}\right)$ to be cloned was found using an expression cloning strategy of mRNA from Xenopus laevis melanophores (Ebisawa et al., 1994); this particular receptor has no known mammalian ortholog, but its discovery led to the cloning of several melatonin receptors from mammals, including two human receptors (Reppert et al., 1994, 1995a).

The first attempts to identify brain melatonin receptors employed $\left[{ }^{3} \mathrm{H}\right]$ melatonin as a radioligand to label binding sites in membranes from bovine hypothalamus, cerebral cortex, and cerebellum (Cardinali et al., 1979). This was followed by the discovery of the first functional melatonin receptor in a neuronal mammalian tissue, the rabbit retina (Dubocovich, 1983, 1985, 1988a). Melatonin, acting via a presynaptic heteroreceptor, inhibits retinal dopamine release, and this bioassay was used to establish the relative order of potency for a series of agonists and putative antagonists as well as to discover the first competitive melatonin antagonist, luzindole (Dubocovich, 1988a,c). Vakkuri et al. (1984) introduced the radioligand 2-[ $\left.{ }^{125} \mathrm{I}\right]$ iodomelatonin as a tracer for use in melatonin radioimmunoassays. This molecule turned out to be the silver bullet of melatonin receptor research in that its selectivity and high specific activity allowed the field to move forward. Soon afterward, several laboratories simultaneously established the use of 2-[ $\left.{ }^{125} \mathrm{I}\right]$ iodomelatonin as a radioligand for receptor localization (Vanecek et al., 1987) and receptor characterization in native tissues (Laudon and Zisapel, 1986; Dubocovich and Takahashi, 1987) (for reviews, see Krause and Dubocovich, 1990; Krause and Dubocovich, 1991; Morgan et al., 1994b; Sugden, 1994; and Dubocovich, 1995).

Melatonin receptors were first classified according to classic pharmacological criteria using data obtained from in vitro bioassays and radioligand binding to native tissues (Cardinali, 1981; Dubocovich, 1988a, 1995; Krause and Dubocovich, 1990; Morgan et al., 1994b). The first classification scheme distinguished two putative receptors, termed $\mathrm{ML}_{1}$ and $\mathrm{ML}_{2}$ receptors, on the basis of kinetic and pharmacological differences observed in 2-[ $\left.{ }^{125} \mathrm{~T}\right]$ iodomelatonin binding sites (Cardinali, 1981; Dubocovich, 1988a, 1995; Krause and Dubocovich, 1990; Morgan et al., 1994b). The $\mathrm{ML}_{1}$ pharmacological profile (2-iodomelatonin > melatonin $\gg N$-acetylserotonin) was exhibited by both $2-\left[{ }^{125} \mathrm{I}\right]$ iodomelatonin binding in mammalian retina and pars tuberalis and the functional presynaptic receptor characterized in rabbit retina (Dubocovich, 1988a, 1995; Krause and Dubocovich, 1990; Morgan et al., 1994b; Hagan and Oakley, 1995). In contrast, $2-\left[{ }^{125} \mathrm{I}\right]$ iodomelatonin binding to the $\mathrm{ML}_{2}$ site (later termed $M T_{3}$ ) in hamster brain membranes was distinguished by another endogenous ligand, $N$-acetylserotonin, that showed equal affinity with melatonin $\left(\mathrm{ML}_{2}\right.$ : 2-iodomelatonin $>$ melatonin $=N$ acetylserotonin) (Dubocovich, 1988b, 1995; Krause and 
Dubocovich, 1990; Pickering and Niles, 1990; Molinari et al., 1996).

The next milestone was the cloning of two mammalian $\mathrm{G}$ protein-coupled melatonin receptors (GPCRs), now termed $\mathrm{MT}_{1}$ and $\mathrm{MT}_{2}$ (formerly Mel1a and Mel1b), (Reppert et al., 1994, 1995a,b, 1996). 2- ${ }^{125}$ I-Iodomelatonin binding to both recombinant $\mathrm{hMT}_{1}$ and $\mathrm{hMT}_{2}$ melatonin receptors exhibits the general pharmacology of the $\mathrm{ML}_{1}$ type (Reppert et al., 1996; Dubocovich et al., 1997). These two melatonin receptors were defined as unique types on the basis of their distinct molecular structure and chromosomal localization (Reppert et al., 1994, 1995a,b, 1996; Slaugenhaupt et al., 1995; Barrett et al., 1997); subsequently, distinguishing ligands were identified (Dubocovich, 1995; Dubocovich et al., 1997; Browning et al., 2000; Faust et al., 2000; Audinot et al., 2003).

The mammalian melatonin binding site $M T_{3}$ (previously referred to as $\mathrm{ML}_{2}$ ) also has been pharmacologically characterized. Both melatonin and its precursor $\mathrm{N}$-acetylserotonin compete for binding of 2-[ $\left.{ }^{125} \mathrm{I}\right]$ iodomelatonin to $M T_{3}$ melatonin binding sites, which show a pharmacological profile distinct from mammalian $\mathrm{G}$ protein-coupled melatonin receptors (Dubocovich, 1995; Molinari et al., 1996; Nosjean et al., 2001). Subsequently, a protein (quinone reductase II; QR2) purified from hamster kidney was found to have a ligand binding profile identical to that of the $M T_{3}$ binding site of hamster brain (Nosjean et al., 2000). In addition, brain and kidney membranes from mice with deletion of the $Q R 2$ gene demonstrated lack of $2{ }^{125} \mathrm{I}-5$-methoxy-carbonylamino- $N$-acetyltryptamine binding to $M T_{3}$ sites (Mailliet et al., 2004).

\section{International Union of Basic and Clinical Pharmacology Criteria for Receptor Nomenclature and Drug Classification}

Melatonin receptors are named and classified on the basis of operational and structural criteria developed by the IUPHAR Committee on Receptor Nomenclature and Drug Classification (Vanhoutte et al., 1996; Ruffolo et al., 2000). The operational criteria are fulfilled by a pharmacological profile of specific ligands at the receptor recognition site, evidence of transduction mechanisms beyond the receptor, and demonstration of endogenously expressed receptors, usually from agonist/ efficacy and antagonist dissociation constants obtained in native tissues. This information, combined with structural data about the protein sequence of the receptor, allows rational classification.

The present classification of melatonin receptors evolved from deliberations of the IUPHAR Subcommittee on Melatonin Receptor Nomenclature and Classification, formed in 1995, as pharmacological, functional, and structural information about the receptors emerged (Table 1). In accordance with IUPHAR guidelines (Vanhoutte et al., 1996; Ruffolo et al., 2000), the receptors were named for their endogenous ligand melatonin,

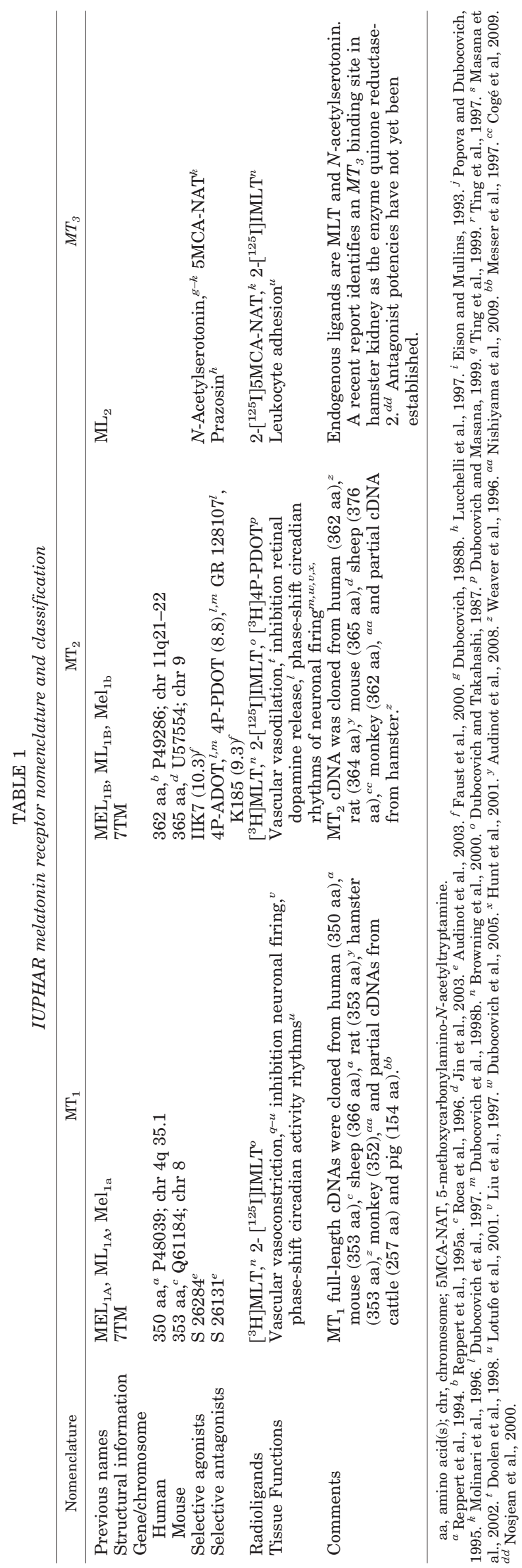


which is abbreviated as "MT" using capital letters, and each particular type of receptor was denoted by a numerical subscript (i.e., $\mathrm{MT}_{1}, \mathrm{MT}_{2}$ ). Species orthologs are denoted by the recommended lower-case prefix (i.e., h, human; o, ovine; r, rat; $\mathrm{m}$, mouse; e.g., $\mathrm{hMT}_{1}$ ). Splice variants, if pharmacologically relevant, would be indicated by lowercase, subscript letters in parentheses [e.g., $\mathrm{MT}_{1(\mathrm{a})}$ ]. No such variants have yet been described for either of the cloned melatonin receptors. The original melatonin receptor nomenclature and classification included the $M T_{3}$ melatonin binding site, which at the time was thought to be a GPCR.

The first nomenclature approved by the IUPHAR Nomenclature Committee for melatonin receptors was published in the IUPHAR compendium in 1998, when melatonin receptors were designated as $\mathrm{mt}_{1}, \mathrm{MT}_{2}$, and $M T_{3}$. (Dubocovich et al., 1998a). The $\mathrm{MT}_{1}$ melatonin receptor was denoted in lower case $\left(\mathrm{mt}_{1}\right)$ because there was no evidence at the time that the native receptor was functional in mammals. Subsequent functional, pharmacological, and immunohistochemical studies, as well as studies with the $\mathrm{MT}_{1}$ knockout (KO) mice, characterized $\mathrm{MT}_{1}$ melatonin receptor protein in native tissues leading to the more recent classification, $\mathrm{MT}_{1}, \mathrm{MT}_{2}$, and $M T_{3}$, published in the 2000 IUPHAR Compendium (Dubocovich et al., 2000).

$M T_{3}$ (formerly $\mathrm{ML}_{2}$ ) was originally included in the classification on the basis of operational criteria (Dubocovich, 1995; Molinari et al., 1996; Dubocovich et al., 1998a, 2000). Because the structure of the receptor protein was not yet established, it was referred to in uppercase italics, as dictated by IUPHAR guidelines. The $M T_{3}$ binding site has a distinct pharmacology with selective agonists and antagonists and similar affinity for two endogenous indoles, melatonin and its precursor, $N$-acetylserotonin. The characterization of $M T_{3}$ as a melatonin binding site on the enzyme QR2 led the IUPHAR Nomenclature Committee to remove the $M T_{3}$ site from the Melatonin Receptor Nomenclature and Classification. We expect the classification of melatonin receptors will continue to evolve as operational and structural data for existing receptors are further defined and possible variants and/or new receptors are characterized. This is the case for the recent cloning of the ovine $\mathrm{MT}_{2}$ receptor, where for many years it was suspected that sheep possessed only one melatonin receptor (Cogé et al., 2009).

\section{Current Melatonin Receptor Nomenclature}

The current nomenclature classifies the two cloned mammalian melatonin receptors into two types: $\mathrm{MT}_{1}$ and $\mathrm{MT}_{2}$. Detailed pharmacological and molecular characterization and supporting scientific evidence for these receptors are described later in this review (Table 1). See also the Melatonin Receptor-IUPHAR database (Dubocovich et al., 2009).
$\mathrm{MT}_{1}$ (formerly $\mathrm{Mel}_{1 \mathrm{a}}, \mathrm{MEL}_{1 \mathrm{~A}}, \mathrm{ML}_{1 \mathrm{~A}}$ ) refers to the first cloned mammalian melatonin receptor (Reppert et al., 1994). It is a $\mathrm{G}_{\mathrm{i} / \mathrm{o}}$ protein-coupled receptor linked, in part, to pertussis-toxin sensitive $G$ proteins that mediate inhibition of cAMP in both recombinant expression systems and native tissues. Functional, immunohistochemical, and genetic KO studies indicate the presence of $\mathrm{MT}_{1}$ receptors in various tissues, including the pars tuberalis of the pituitary gland (von Gall et al., 2002a) and the SCN of the hypothalamus (Dubocovich et al., 2005; Dubocovich, 2007).

$\mathrm{MT}_{2}$ (formerly $\mathrm{Mel}_{1 \mathrm{~b}}, \mathrm{MEL}_{1 \mathrm{~B}}, \mathrm{ML}_{1 \mathrm{~B}}$ ) refers to the second cloned mammalian melatonin receptor (Reppert et al., 1995a). It is a $\mathrm{G}_{\mathrm{i} / \mathrm{o}}$ protein-coupled receptor capable of inhibiting cAMP and cGMP production in recombinant systems and stimulating $\mathrm{PKC}$ activity in a native tissue, the SCN. The pharmacological profile of this receptor was initially characterized in the retina and was defined by the use of selective $\mathrm{MT}_{2}$ melatonin receptor antagonists (4P-PDOT and 4P-ADOT) (Dubocovich et al., 1997).

It is important to note that IUPHAR nomenclature criteria are applied only to mammalian receptors because they are the most closely aligned with therapeutics. The melatonin receptor field, however, actively encompasses a variety of species and has greatly benefited from the initial characterizations and cloning of melatonin receptors that occurred using frog melanophores (Sugden, 1989; Ebisawa et al., 1994; Sugden et al., 2004). At this point, there is no official consensus on classifying nonmammalian receptors, such as the cloned $\mathrm{Mel}_{1 \mathrm{c}}$ subtype that is found in birds and amphibians (Reppert et al., 1995b).

\section{G Protein-Coupled Melatonin Receptor Family}

\section{A. Protein Structure}

The $\mathrm{MT}_{1}$ and $\mathrm{MT}_{2}$ melatonin receptors comprise their own subgroup within the GPCR superfamily. Both melatonin receptors have a general structural motif consisting of seven transmembrane (TM)-spanning $\alpha$-helical segments connected by alternating intracellular and extracellular loops, with the amino terminus located on the extracellular side and the carboxyl terminus on the intracellular side (Fig. 3). These seven $\alpha$-helical segments contain stretches of 20 to 25 predominantly hydrophobic residues that span the cell membrane. The melatonin receptors are classified with the rhodopsin $/ \beta_{2}$-adrenergic receptor family (Deupi et al., 2007). Within this family, most of the sequence homology between the melatonin receptors and other $G$ protein-linked receptors occurs within the TM domains (Fig. 4).

The human $\mathrm{MT}_{1}$ and $\mathrm{MT}_{2}$ melatonin receptors encode proteins of 350 and 362 amino acids, respectively. Their predicted mass is 39,374 and 40,188 Da, respectively; however, these numbers do not take into account possi- 


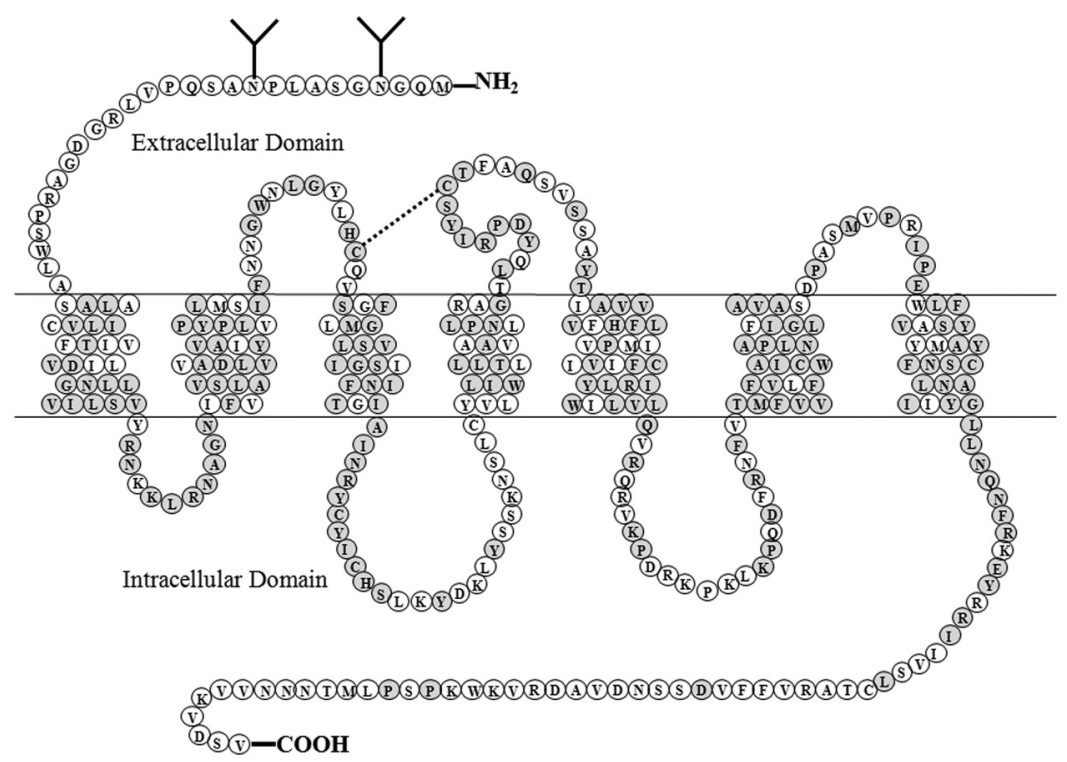

FIG. 3. Membrane topology of the $\mathrm{hMT}_{1}$ melatonin receptor showing amino acids conserved in the $\mathrm{hMT}_{2}$ receptor. Gray circles denote amino acids identical in the $\mathrm{hMT}_{1}$ and $\mathrm{hMT}_{2}$ melatonin receptors. The two glycosylation sites on the $\mathrm{hMT}_{1}$ receptor are denoted (Y) in the $\mathrm{N}$ terminus. [Adapted from Reppert SM and Weaver DR (1995) Melatonin madness. Cell 83:1059-1062. Copyright @ 1995 Elsevier Inc. Used with permission.]

ble postranslational modifications. The amino acid homology for the human $\mathrm{MT}_{1}$ and $\mathrm{MT}_{2}$ melatonin receptors is approximately $60 \%$ overall and $73 \%$ within the transmembrane domains. The amino terminus of the $\mathrm{MT}_{1}$ melatonin receptor contains two consensus sites for Nterminal asparagine-linked glycosylation, whereas that of the $\mathrm{MT}_{2}$ shows only one site. The carboxyl tail of the two receptors contain consensus sites for casein kinase $1 \alpha$, casein kinase II, and protein kinase $\mathrm{C}$ as well as postsynaptic density $95 /$ disc-large/zona occludens binding domains that may participate in membrane localization and trafficking (Hung and Sheng, 2002). Features that distinguish the melatonin receptor family from other GPCRs include a NRY motif downstream from the third transmembrane domain and a NAXIY in transmembrane domain 7, rather than DRY and NPXXY motifs, respectively (Reppert et al., 1994, 1995a; Roca et al., 1996).

\section{B. Gene Structure and Chromosomal Localization}

Molecular analyses of genomic clones show that the genes that encode the human $\mathrm{MT}_{1}$ and $\mathrm{MT}_{2}$ melatonin receptors are formed by two exons separated by an $\sim 13-$ kilobase intron (Reppert et al., 1995a; Slaugenhaupt et al., 1995; Roca et al., 1996). The intron in the first cytoplasmic loop of the $\mathrm{MT}_{1}$ and $\mathrm{MT}_{2}$ melatonin receptor genes could potentially lead to alternative splice forms with distinct receptor structure, as well as operational and transduction characteristics. Such functional splice variants, however, have not yet been identified. It is noteworthy that the rat $\mathrm{MT}_{2}$ receptor is composed of three exons, although the last exon contains no open reading frames (Ishii et al., 2009).

The melatonin receptors show distinct chromosomal localization. The $\mathrm{MT}_{1}$ melatonin receptor was localized to human chromosome 4q35.1 and mouse chromosome 8 (Slaugenhaupt et al., 1995; Roca et al., 1996). Slaugenhaupt et al. (1995) identified a region of syntenic conservation between distal chromosome 4 and mouse chromosome 8 that includes the genes plasma kallikrein $(K L K 3)$, mitochondrial uncoupling protein (UPC), and coagulation factor XI (F11) (Beaubien et al., 1991; Mills et al., 1992). By contrast, the $\mathrm{MT}_{2}$ melatonin receptor maps to human chromosome 11q21-22 (Reppert et al., 1995a). Reppert et al., 1995 (Reppert et al., 1995a), pointed out that the $\mathrm{hMT}_{2}$ receptor maps to a region syntenic to mouse chromosome 9 in the region of the D2 dopamine receptor ( $\operatorname{Drd} 2)$ and thymus cell antigen 1 (thy) loci (Seldin et al., 1991; Goldsborough et al., 1993).

The phylogenetic tree of the melatonin receptors $\left(\mathrm{MT}_{1}, \mathrm{MT}_{2}\right.$, and $\left.\mathrm{Mel}_{1 \mathrm{C}}\right)$ and the melatonin-related receptor GPR50 (also known as melatonin-related receptor or H9) sequences revealed that GPR50, which cannot bind melatonin, is relatively distant to the functional melatonin receptors $\left(\mathrm{MT}_{1}, \mathrm{MT}_{2}, \mathrm{Mel}_{1 \mathrm{C}}\right)$. The $\mathrm{Mel}_{1 \mathrm{C}}$ receptor, which is not expressed in mammals, is phylogenetically closer to the $\mathrm{MT}_{2}$ receptor than to the $\mathrm{MT}_{1}$ receptor. The human $\mathrm{MT}_{1}$ receptor shows more similarities with the rodent $\mathrm{MT}_{1}$ receptors than with the bovine, ovine, and porcine $\mathrm{MT}_{2}$ receptors. As already observed for other GPCRs, the ovine $\mathrm{MT}_{1}$ receptor shows significant homology with the bovine $\mathrm{MT}_{1}$ receptor (Fig. 4).

Whereas the $\mathrm{Mel}_{1 \mathrm{C}}$ receptor has been found only in fish, birds, and X. laevis, GPR50 has only been found in eutherian mammals and not birds or fish. An in silico approach has suggested that GPR50 is the ortholog of the $\mathrm{Mel}_{1 \mathrm{C}}$ receptor (Dufourny et al., 2008). This conclusion is based on an analysis of the melatonin receptor family phylogenetic tree and the conserved synteny of genes surrounding the $\mathrm{Mel}_{1 \mathrm{C}}$ and GPR50 genes. It is 


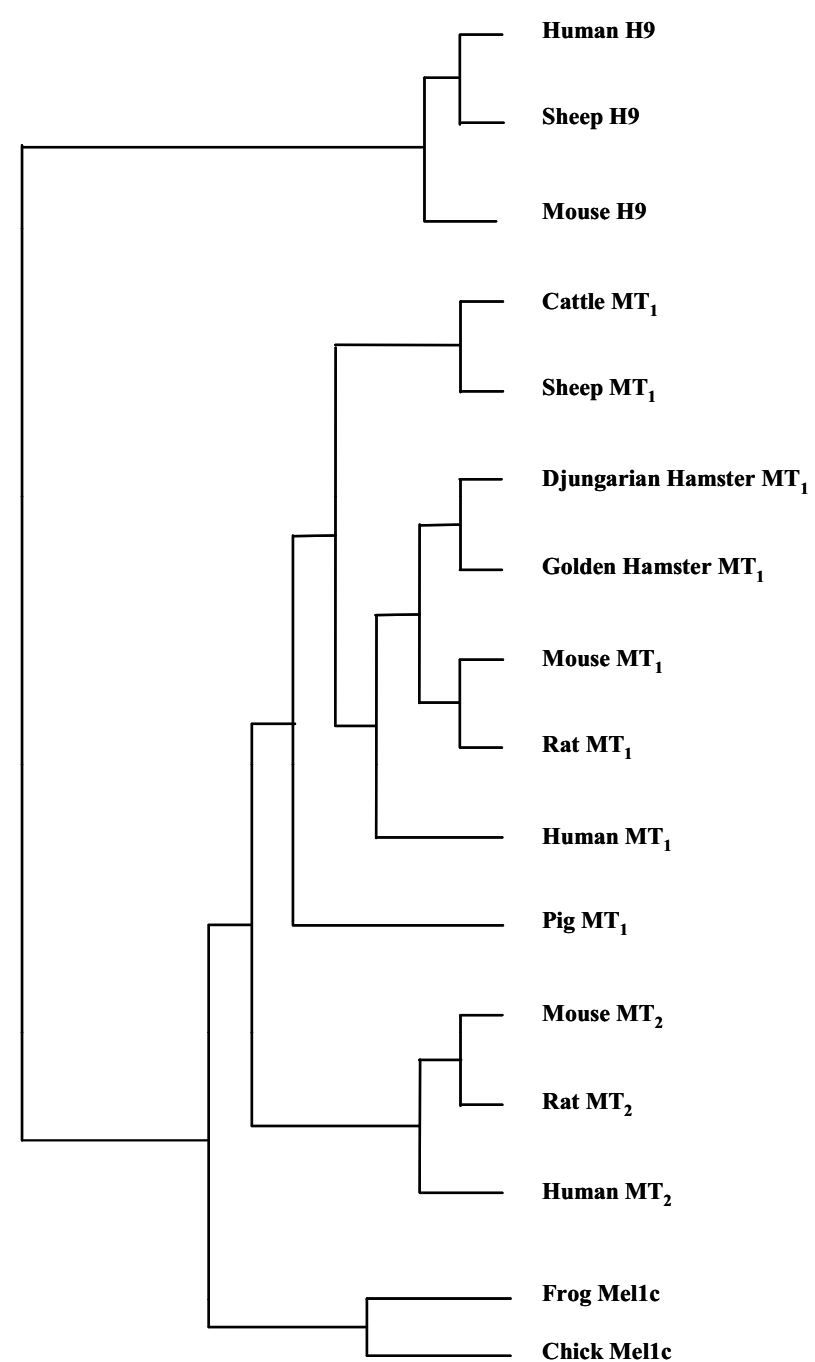

Fig. 4. $\mathrm{MT}_{1}$ and $\mathrm{MT}_{2}$ melatonin receptor dendrogram. Phylogenetic tree of melatonin receptor or melatonin receptor-related (GPR50, melatonin-related receptor or H9) sequences. The evolutionary distances between the different sequences were calculated with the matrix of Blosum 62 score. The tree was drawn using the Unweighted Pair Group Method with Arithmetic mean (UPGMA). GenBank accession numbers and the number of amino acids for each receptor are as follows: human H9: U52219, 613; sheep H9: U52221, 613; mouse H9: AF065145, 791; cattle $\mathrm{MT}_{1}$ : U73327, 257; sheep $\mathrm{MT}_{1}$ : U14109, 366; Djungarian hamster $\mathrm{MT}_{1}$ : U14110, 353; golden hamster MT 1 : AF061158, 325; mouse $\mathrm{MT}_{1}$ : U52222, 353; rat $\mathrm{MT}_{1}$ : $\mathrm{AF} 130341,326$; human $\mathrm{MT}_{1}$ : U14108, 350; Pig $\mathrm{MT}_{1}$ : U73326, 154; mouse $\mathrm{MT}_{2}$ : AY145850, 365; rat $\mathrm{MT}_{2}$ : $\mathrm{U} 28218,120$; human $\mathrm{MT}_{2}$ : U25341, 362. The sequences for cattle and pig $\mathrm{MT}_{1}$ receptors have been partially cloned.

suggested that rapid evolution of $\mathrm{Mel}_{1 \mathrm{C}}$ into GPR50 led to the mutation of several critical amino acids and the addition of a long $\mathrm{C}$-terminal tail resulting in the loss of affinity of GPR50 for melatonin. However, formation of the GPR50/MT $\mathrm{M}_{1}$ receptor heterodimer in recombinant cells significantly reduces the affinity and potency of melatonin agonists binding for the $\mathrm{MT}_{1}$ melatonin receptor (Levoye et al., 2006a). Recent evidence supports the idea that GPR50 expression in the Siberian hamster ependymal layer is under photoperiod control (Barrett et al., 2006). This orphan receptor may also be important in regulating energy metabolism (Ivanova et al., 2008).
The $\mathrm{MT}_{2}$ melatonin receptor gene cloned from the Siberian or Syrian hamsters seems to be a pseudogene because it is endowed with two nonsense mutations in the coding region of the receptor cDNA. The stop codons are located in transmembrane domain $\mathrm{V}$ and in the second extracellular loop (Weaver et al., 1996). The Siberian and Syrian hamster are considered natural $\mathrm{MT}_{2}$ melatonin receptor mutants.

\section{Melatonin Receptor Polymorphisms}

Genetic polymorphisms have been reported for melatonin receptors in human and sheep. In human, polymorphisms have been compared for both $\mathrm{MT}_{1}$ and $\mathrm{MT}_{2}$ in subjects with circadian rhythm sleep disorders and controls. Seven mutations were found in the $\mathrm{MT}_{1}$ receptor, with two that resulted in amino acid changes: R54W in the first cytoplasmic loop and A157V in the fourth transmembrane domain (Ebisawa et al., 1999). Although the mutations were more common in non-24-h sleep-wake syndrome subjects than in delayed sleep phase syndrome or controls, no significant change in receptor affinity and/or density was observed when the mutants were expressed in heterologous cells. Two mutations were also reported for the $\mathrm{hMT}_{2}$ : G24E in the $\mathrm{N}$-terminal domain and $\mathrm{L} 66 \mathrm{~F}$ in the first cytoplasmic loop. However, neither shows altered $\mathrm{MT}_{2}$ receptor binding characteristics (Ebisawa et al., 2000). The effect of these mutations in melatonin receptor function has not been reported.

Melatonin secretion follows a circadian rhythm with high levels at night. By contrast, insulin release is high during the day. The drop in insulin levels at night may result from endogenous melatonin-mediated inhibition by activation of $\mathrm{MT}_{1}$ and $\mathrm{MT}_{2}$ in pancreatic islets (Peschke et al., 2002; Mulder et al., 2009). Recent studies have revealed an association of high fasting plasma glucose, early stage impairment of insulin secretion, and increased risk of type 2 diabetes in persons with genetic variations in the MTNR1B gene encoding the $\mathrm{MT}_{2}$ melatonin receptor (Bouatia-Naji et al., 2009; Lyssenko et al., 2009; Prokopenko et al., 2009). Based on increases in $\mathrm{MT}_{2}$ melatonin receptor mRNA expression in human pancreatic islets of subjects without diabetes with the risk allele and subjects with type 2 diabetes led to the suggestion that an increase in $\mathrm{MT}_{2}$ receptor density may be involved in the pathogenesis of these conditions (Lyssenko et al., 2009). However, whether increases in mRNA expression reflect increases in $\mathrm{MT}_{2}$ melatonin receptor density in pancreatic islets is not known.

Several polymorphisms have been described in the ovine $\mathrm{MT}_{1}$ type, leading to changes in amino acids (A282D, H358R, I361V), one in extracellular loop 3 and two in the carboxyl-terminal tail. This variant receptor, which seems fully functional, has not been linked with a specific phenotype (Barrett et al., 1997). Polymorphism of MnlI restriction sites in exon II of the $\mathrm{MT}_{1}$ receptor 
was analyzed in the Mérinos d'Arles ewe in relation to the expression of reproductive seasonality (Pelletier et al., 2000). The MnlI restriction sites show an association between the homozygous genotype for the absence of a MnlI site at position $605(-/-)$ and seasonal anovulatory activity. Other mutations were observed, not simultaneously, at positions 706 and 893, which resulted in the substitution of a valine by an isoleucine and of an alanine by an aspartic acid, respectively. However, in the Ile-de-France sheep breed, the two allelic forms of the $\mathrm{MT}_{1}$ receptor gene have no direct effect on the seasonal pattern of various seasonal functions. It was suggested that the effect of this polymorphism on seasonal function seems to be dependent on the breed and/or environmental condition (Hernandez et al., 2005).

\section{Molecular Structure of $M T_{1}$ and $M T_{2}$ Melatonin Receptor Ligand Binding Pockets}

1. $M T_{1}$ Melatonin Receptor. A rhodopsin-based computer model has been used to propose the molecular structure of the melatonin receptor binding site (Navajas et al., 1996). This particular model has advantages over bacteriorhodopsin-based models for the melatonin receptor binding site (Sugden et al., 1995; Grol and Jansen, 1996), because bacteriorhodopsin is not coupled to $\mathrm{G}$ proteins, and its sequence has none of the distinctive features of the GPCR family (Baldwin, 1993). The rhodopsin-based molecular model has been investigated by site-directed mutagenesis studies, revealing that the binding site of the melatonin receptor has some similarities with those of other GPCRs of the rhodopsin/ $\beta_{2^{-}}$ adrenergic receptor family. For example, His195 in putative TM5 is conserved in all of the melatonin receptors, and the position is identical to that used in the ligand binding site of many other rhodopsin-like GPCRs. The model proposes that this His residue can form a hydrogen bond with the oxygen atom of the 5-methoxy group of melatonin. Site-directed mutagenesis of the melatonin receptor (Conway et al., 1997; Kokkola et al., 1998) and studies with sulfur analogs of melatonin (Davies et al., 2004) have given support to this suggestion. The binding site model also proposes that Val192, which is located approximately one helical turn above the His195 facing the hydrophobic binding pocket, is important for the binding of the methyl portion of the methoxy group of melatonin. Val192 is analogous to a residue in the $\beta_{2}$-adrenergic and 5-HT receptors that is important in ligand binding (Strader et al., 1989; Ho et al., 1992; Kao et al., 1992). In addition, Met107 in TM3 and Ser280 and Ala284 in TM7, which were proposed to be important for the binding of the $N$-acetyl group of melatonin, do not seem to directly participate in melatonin receptor activation (Kokkola et al., 1998). Thus, computer modeling has revealed one site that is important for melatonin binding, but the other residues/domain(s) of the melatonin receptor, which are critical for ligand binding, have yet to be identified.
A second method for determining residues that are important for receptor binding and activation has been to modify amino acid residues conserved in the rhodopsin-like GPCRs. Protonation of the aspartic/glutamic acid in the highly conserved D/ERY motif at the cytoplasmic side of TM3 is believed to be involved in activation of the rhodopsin-like GPCRs. The binding of the ligand causes the Asp/Glu to become unprotonated, resulting in receptor activation, as shown most directly by the rhodopsin receptor (Arnis et al., 1994). Changing the $\mathrm{D} / \mathrm{E}$ to a neutral amino acid that mimics the unprotonated state results in constitutive activation and improved coupling of many of the rhodopsin-like receptors. The melatonin receptor is unique in that it has an NRY motif instead of the D/ERY motif. Changing the NRY to an ARY (mimicking the unprotonated, activated state) actually decreases binding to such an extent that it is impossible to measure receptor activation (Nelson et al., 2001). Changing the melatonin receptor NRY motif to the D/ERY motif modestly decreases the binding affinity (2-fold) and decreases the capacity for melatonin to activate the receptor (Nelson et al., 2001). Thus, unlike other rhodopsin-like GPCRs, the melatonin receptor seems to not require deprotonation of the NRY motif to be active, and Asn is needed for optimal ligand binding and receptor activation.

Pro267 is a highly conserved amino acid in rhodopsinlike GPCRs. This proline residue occurs in the center of TM6, causing a kink in the center of the $\alpha$-helix. Mutating the proline to an alanine results in constitutive activity of the yeast $\alpha$-factor and $\beta_{2}$-adrenergic receptor (Konopka et al., 1996), presumably by making the alpha helix less "kinked." However, when the corresponding residue in the $\mathrm{MT}_{1}$ melatonin receptor, $\alpha 253$, is mutated to Ala, constitutive activity of the melatonin receptor is not seen and, in fact, the receptor affinity is decreased by severalfold (Kokkola et al., 1998).

G-protein coupled melatonin receptors have two conserved cysteines (Cys127, Cys130) between helix III and the second intracellular loop, a region important in receptor/G-protein coupling. Indeed, mutation of Cys127 and Cys130 to Ser in the $\mathrm{MT}_{1}$ receptor revealed that these cysteines are necessary for normal $G$ protein activation and receptor trafficking (Kokkola et al., 2005).

Finally, there is an NPXXY sequence found at the end of TM7 in rhodopsin-like receptors. The Asn302 is proposed to interact with the Asp83, suggesting that TM2 and TM7 are in close proximity. Kinking and twisting of Pro303 is proposed to allow these two residues to come in contact. It is noteworthy that the melatonin receptors have retained the conserved Asp83 (Asp73) and Asn302 (Asn291) but have replaced the Pro303 with an alanine (Ala292). How the Ala292 affects the overall structural motif is not known (Table 2).

Analysis of rhodopsin binding and of extensive mutagenesis data involving the $\beta_{2}$ adrenergic receptor suggests that TMs $3,5,6$, and 7 , especially TM3 and/or 


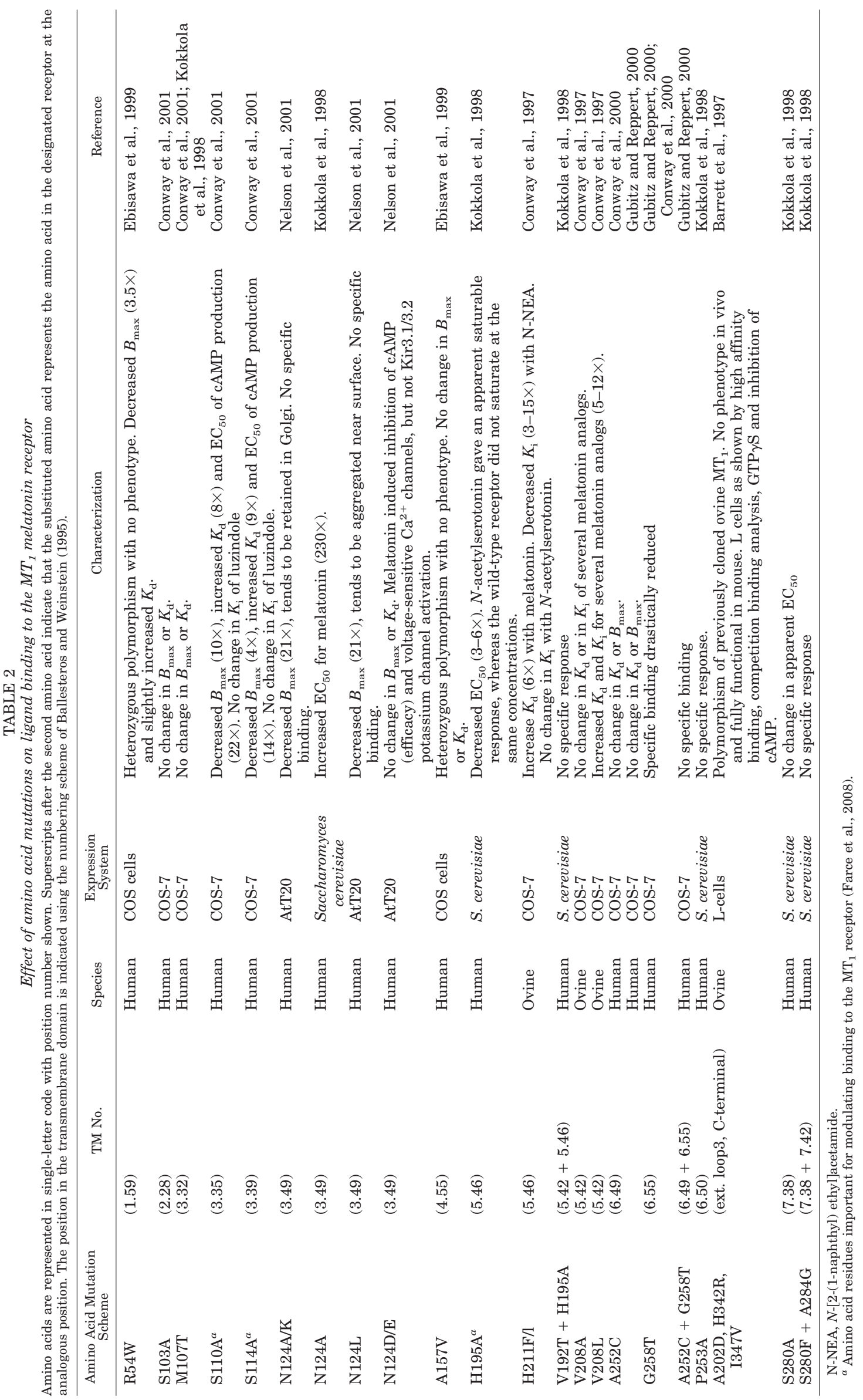


TM7, are major players in ligand binding (Kobilka and Deupi, 2007; Rosenbaum et al., 2007). The TM3 domains of ClassA GPCRs contain a high number of Ser/Thr/Cys residues (seven residues/TM3). These residues form hydrogen bonds to the peptide backbone and thereby bend and twist helices (Gray and Matthews, 1984; Ballesteros et al., 2000). Thus, different hydrogen bonding states may result in different TM3 conformations that represent different functional states of the same receptor, such as liganded versus unliganded or active versus inactive (Ballesteros et al., 2001). As in other GPCRs, the Ser/Thr/Cys residues in TM3 of $\mathrm{MT}_{1}$ are important in ligand binding at $\mathrm{MT}_{1}$ receptors. Mutations of Ser110 and Ser114, but not Ser103, to alanine reduced melatonin binding but did not affect luzindole binding (Conway et al., 2001). These experiments give some molecular support to the experimental data from the structureactivity relationships of a series of luzindole analogs suggesting that melatonin receptor agonist and antagonist-binding sites may differ (Teh and Sugden, 1998) (Table 2). Based on these studies, a two dimensional model of the $\mathrm{MT}_{1}$ melatonin receptor was created comprising the transmembrane domains and the potential orientation of melatonin in the binding pocket (Barrett et al., 2003). This model takes into account the interaction between melatonin's methoxy group and the conserved histidine (His195) in TM5.

A third method for determining important residues for melatonin receptor binding has been to create chimeric melatonin $\mathrm{MT}_{1}$ and melatonin-related receptors (GPR50). Despite having 57\% amino acid sequence identity with the TM domains of the $\mathrm{MT}_{1}$ receptor, the GPR50 does not bind 2-[ $\left.{ }^{125} \mathrm{I}\right]$ iodomelatonin or $\left[{ }^{3} \mathrm{H}\right] \mathrm{me}-$ latonin. It is noteworthy that two studies involving chimeric receptors suggest that TM6, extracellular loop 2, and intracellular loop 2 are critical for melatonin receptor binding to the $\mathrm{MT}_{1}$ melatonin receptor. Replacement of transmembrane domains 1, 2, 3, 5, or 7 of the $\mathrm{hMT}_{1}$ receptor by the corresponding TM from GPR50 induces only minor change in 2 - $\left[{ }^{125} \mathrm{I}\right]$ iodomelatonin binding affinity. On the contrary, chimeric receptors with TM 6 from GPR50 receptor display no specific binding (Conway et al., 2000; Gubitz and Reppert, 2000). Gubitz and Reppert (2000) reported that replacement of TM4 of the $\mathrm{hMT}_{1}$ with TM4 of GPR50 did not alter binding affinity, but Conway et al. (2000) failed to detect specific binding in this mutant. To confirm that some specific amino acids of TM 6 play an important role in binding, both research groups performed point mutations in this transmembrane of the $\mathrm{MT}_{1}$ receptor. Mutation of glycine to threonine $(\mathrm{G} 258 \mathrm{~T})$ severely reduced both the binding and activation of the $\mathrm{MT}_{1}$ receptor (Conway et al., 2000; Gubitz and Reppert, 2000). The mutant A252C displayed binding affinity close to that of the native $\mathrm{hMT}_{1}$ receptor. Double mutation of glycine to threonine $(\mathrm{G} 258 \mathrm{~T})$ and alanine to cysteine (A252C) was found to completely inhibit binding by Gubitz and Reppert (2000) and to have no effect on binding by Conway et al. (2000). Taken together, these data do support the idea that mutation of glycine 258 , which is predicted to face the hydrophilic receptor core, may be important for maintaining an appropriate $\mathrm{MT}_{1}$ melatonin receptor structure.

2. $M T_{2}$ Melatonin Receptor. Melatonin receptors, like most other GPCRs, contain a conserved cysteine residue in extracellular loop 1 and in extracellular loop 2. Mutation of these Cys residues in rhodopsin (Karnik et al., 1988), $\delta$-opioid (Ehrlich et al., 1998), plateletactivating factor (Le Gouill et al., 1997), and $\mathrm{M}_{3}$ muscarinic receptors (Zeng et al., 1999) demonstrate the critical importance of this disulfide bond for the proper receptor conformation for ligand binding, receptor activation, and cell surface expression. These conserved cysteine residues, however, do not always participate in disulfide bonding, as shown previously for the $\beta 2$-adrenergic receptor (Noda et al., 1994). The disulfide bond formation between Cys113 and Cys190 residues was shown to be crucial to maintain a proper $\mathrm{hMT}_{2}$ receptor conformation for melatonin binding without altering cell surface receptor expression (Mseeh et al., 2002). Whether this disulfide bond occurs within a single melatonin receptor or between two melatonin receptors forming a dimer remains to be determined. $N$-ethylmaleimide alkylation of Cys140 appears to contribute to changes in ligand affinity, whereas alkylation of Cys143 and Cys219 reduced binding capacity (Mseeh et al., 2002). The cysteines involved in $N$-ethylmaleimide-induced changes in affinity and receptor density are probably located in receptor regions near the melatonin binding site and/or G protein coupling region.

Key conserved amino acids (Table 3 ) seem to be involved in ligand binding to the $\mathrm{MT}_{2}$ melatonin receptors as determined in binding studies after mutation to alanine. Mutation of Asn175 in TM4 or His208 in TM5 of the $\mathrm{hMT}_{2}$ melatonin receptor significantly decreased the binding affinity for melatonin (Gerdin et al., 2003). Asn175 in TM4 seems to facilitate binding of the 5-methoxy group of the melatonin molecule to the $\mathrm{hMT}_{2}$ melatonin receptor (Gerdin et al., 2003). Thus, His208 in TM5 in both the oMT 1 receptor (Conway et al., 1997) and the $\mathrm{hMT}_{2}$ melatonin receptor (Gerdin et al., 2003) are critical for melatonin binding. Trp264 or Phe257 in TM6, although not critical for melatonin binding, may interact with aromatic regions of molecules such as luzindole and 4P-ADOT. Mutation of Ser123 or Ser127 in TM3 or Ser293 in TM7 of the MT2 receptor did not affect binding affinity, although equivalent serines (Ser110 and Ser114 in TM3) were reported to be critical for melatonin binding to the $\mathrm{hMT}_{1}$ melatonin receptor (Conway et al., 2001). Thus, the binding pockets of the $\mathrm{MT}_{1}$ and $\mathrm{MT}_{2}$ melatonin receptors seem to share a common histidine residue (His195/208 in TM5) but also have distinct residues (Ser110/123 and Ser110/127 in TM3) necessary for 
TABLE 3

Effect of amino acid mutations on ligand binding to the $h M T_{2}$ melatonin receptor

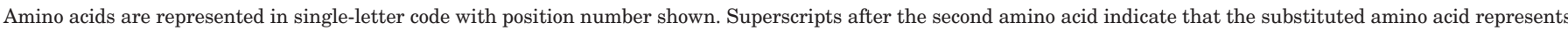

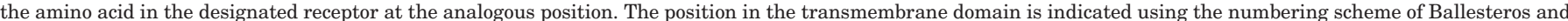
Weinstein (1995).

\begin{tabular}{|c|c|c|c|c|}
\hline $\begin{array}{l}\text { Amino Acid Mutation } \\
\text { Scheme }\end{array}$ & TM No. & $\begin{array}{l}\text { Expression } \\
\text { System }\end{array}$ & Characterization & Reference \\
\hline \multicolumn{5}{|c|}{ 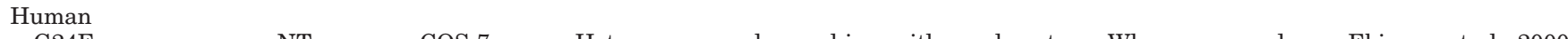 } \\
\hline G24E & NTerm & COS-7 & $\begin{array}{l}\text { Heterozygous polymorphism with no phenotype. When expressed } \\
\text { in COS- } 7 \text { cells no change in } K_{\mathrm{d}} \text { or } K_{\mathrm{i}} \text { with melatonin. }\end{array}$ & Ebisawa et al., 2000 \\
\hline $\mathrm{L} 66 \mathrm{~F}$ & 1.58 & COS-7 & Heterozygous polymorphism with no phenotype. & Ebisawa et al., 2000 \\
\hline C113A & ECL1 & HEK293 & No specific binding. & Mseeh et al., 2002 \\
\hline $\mathrm{C} 140 \mathrm{~A}$ & ICL2 & HEK293 & $\begin{array}{l}\text { No change in } K_{\mathrm{d}} \text {, slightly increased } K_{\mathrm{i}} \text { for melatonin }(1.6 \times) \text {, } \\
\text { decreased } B_{\max }(22 \times) \text {. }\end{array}$ & Mseeh et al., 2002 \\
\hline $\mathrm{C} 143 \mathrm{~A}$ & ICL2 & HEK293 & $\begin{array}{l}\text { No change in } K_{\mathrm{d}} \text {, slightly increased } K_{\mathrm{i}} \text { for melatonin }(1.4 \times) \text {, } \\
\text { slightly increased } B_{\max }(1.8 \times) \text {. }\end{array}$ & Mseeh et al., 2002 \\
\hline C190A & ECL2 & HEK293 & No specific binding. & Mseeh et al., 2002 \\
\hline C219A & 5.57 & HEK293 & No change in $K_{\mathrm{d}}$ or $K_{\mathrm{i}}$. Decreased $B_{\max }(5 \times)$. & Mseeh et al., 2002 \\
\hline $\mathrm{C} 263 \mathrm{~A}$ & 6.47 & HEK293 & No change in $K_{\mathrm{d}}$ or $K_{\mathrm{i}}$. Decreased $B_{\max }^{\max }(31 \times)$. & Mseeh et al., 2002 \\
\hline C302A & 7.47 & HEK293 & No change in $K_{\mathrm{d}}$ or $K_{\mathrm{i}}$. Decreased $B_{\max }^{\max }(4 \times)$. & Mseeh et al., 2002 \\
\hline S123A & 3.35 & HEK293 & No change in $K_{\mathrm{d}}$ or $K_{\mathrm{i}}$. Decreased $B_{\max }(5 \times)$. & Gerdin et al., 2003 \\
\hline S127A & 3.39 & HEK293 & No change in $K_{\mathrm{d}}$ or $K_{\mathrm{i}}$. Decreased $B_{\max }(3 \times)$ & Gerdin et al., 2003 \\
\hline $\mathrm{N}_{175 \mathrm{~A}^{a}}$ & 4.60 & HEK293 & $\begin{array}{l}\text { No change in } K_{\mathrm{d}} \text {, slightly increased } K_{\mathrm{i}} \text { for melatonin. No change } \\
\text { in } B_{\max } \text {. }\end{array}$ & Gerdin et al., 2003 \\
\hline $\mathrm{H} 208 \mathrm{~A}^{a}$ & 5.46 & HEK293 & Increased $K_{\mathrm{d}}$ and $K_{\mathrm{i}}$ for melatonin. No change in $B_{\max }$ & Gerdin et al., 2003 \\
\hline F257A & 6.41 & HEK293 & No change in $K_{\mathrm{d}}$ or $K_{\mathrm{i}}$. No change in $B_{\max }$. & Gerdin et al., 2003 \\
\hline W264A & 6.48 & HEK293 & Decreased $K_{\mathrm{d}}$, no change in $K_{\mathrm{i}}$. Decreased $B_{\max }(22 \times)$. & Gerdin et al., 2003 \\
\hline S293A & 7.38 & HEK293 & No change in $K_{\mathrm{d}}$ or $K_{\mathrm{i}}$. No change in $B_{\max }$. & Gerdin et al., 2003 \\
\hline $\mathrm{V} 204 \mathrm{~A}^{a}$ & 5.42 & HEK293 & No specific binding. & Mazna et al., 2004 \\
\hline V205 & 5.43 & HEK293 & No change in $K_{\mathrm{d}}$. No change in $B_{\max }$ & Mazna et al., 2004 \\
\hline F209A & 5.47 & HEK293 & $\begin{array}{l}\text { No change in } K_{\mathrm{d}} \text {. Decreased } B_{\max } \text {. No change in } K_{\mathrm{i}} \text { for melatonin, } \\
\text { luzindole or } 4 \mathrm{P} \text {-PDOT. }\end{array}$ & Mazna et al., 2004 \\
\hline G271T & 6.55 & HEK293 & Not saturable. & Mazna et al., 2004 \\
\hline $\mathrm{L}_{2} 2 \mathrm{~A}^{a}$ & 6.56 & HEK293 & No specific binding. & Mazna et al., 2004 \\
\hline $\mathrm{Y}_{298 \mathrm{~A}^{a}}$ & 7.43 & HEK293 & No specific binding. & Mazna et al., 2004 \\
\hline M120A & 3.32 & HEK293 & No change in $K_{\mathrm{d}}$ or $B_{\max }$. & Mazna et al., 2005 \\
\hline G121A & 3.33 & HEK293 & No change in $K_{\mathrm{d}}$ or $B_{\max }$. & Mazna et al., 2005 \\
\hline G121I & 3.33 & HEK293 & No change in $K_{\mathrm{d}}$ or $B_{\max }$ & Mazna et al., 2005 \\
\hline V124A & 3.36 & HEK293 & No change in $K_{\mathrm{d}}$ with decreased $B_{\max }$. & Mazna et al., 2005 \\
\hline $\mathrm{I} 125 \mathrm{~A}$ & 3.37 & HEK293 & No change in $K_{\mathrm{d}}$ or $B_{\max }$. & Mazna et al., 2005 \\
\hline Y188A & ECL2 & HEK293 & No specific binding. & Mazna et al., 2005 \\
\hline Y188F & ECL2 & HEK293 & No specific binding. & Mazna et al., 2005 \\
\hline $\mathrm{N}_{268 \mathrm{~A}^{a}}$ & 6.52 & HEK293 & No specific binding. & Mazna et al., 2005 \\
\hline $\mathrm{N}^{268 \mathrm{D}^{a}}$ & 6.52 & HEK293 & No specific binding. & Mazna et al., 2005 \\
\hline $\mathrm{N} 268 \mathrm{~L}^{a}$ & 6.52 & HEK293 & No specific binding. & Mazna et al., 2005 \\
\hline $\mathrm{N}_{2} 68 \mathrm{Q}^{\alpha}$ & 6.52 & HEK293 & No change in $K_{\mathrm{d}}$ or $B_{\max }$. & Mazna et al., 2005 \\
\hline $\mathrm{A} 275 \mathrm{I}$ & 6.59 & HEK293 & No specific binding. & Mazna et al., 2005 \\
\hline $\mathrm{A} 275 \mathrm{~V}^{a}$ & 6.59 & HEK293 & No change in $K_{\mathrm{d}}$ or $B_{\max }$. & Mazna et al., 2005 \\
\hline $\mathrm{V}_{291 \mathrm{~A}^{a}}$ & 7.36 & HEK293 & No specific binding. & Mazna et al., 2005 \\
\hline $\mathrm{V}^{2} 91 \mathrm{I}^{a}$ & 7.36 & HEK293 & No specific binding. & Mazna et al., 2005 \\
\hline $\mathrm{L}_{295 A^{a}}$ & 7.40 & HEK293 & No specific binding. & Mazna et al., 2005 \\
\hline $\mathrm{L}_{2} 295 \mathrm{I}^{a}$ & 7.40 & HEK293 & No specific binding. & Mazna et al., 2005 \\
\hline $\mathrm{L}_{295 \mathrm{~V}^{a}}$ & 7.40 & HEK293 & No specific binding. & Mazna et al., 2005 \\
\hline \multicolumn{5}{|l|}{ Hamster } \\
\hline $\mathrm{P} 41 \mathrm{~A}$ & 1.33 & $\mathrm{CHO}-\mathrm{K} 1$ & $\begin{array}{l}\text { No change in } K_{\mathrm{d}} \text { or } B_{\max } \text {. No change in } \mathrm{EC}_{50} \text { or } E_{\max } \text { for } \\
\text { melatonin or } 2 \text {-iodomelatonin stimulation of } \mathrm{GTP} \gamma^{35} \mathrm{~S} \text { binding. }\end{array}$ & Mazna et al., 2008 \\
\hline P93A & 2.57 & CHO-K1 & $\begin{array}{l}\text { No change in } K_{\mathrm{d}} \text { or } B_{\max } \text {. No change in } \mathrm{EC}_{50} \text { or } E_{\max } \text { for } \\
\text { melatonin or } 2 \text {-iodomelatonin stimulation of } \mathrm{GTP} \gamma^{35} \mathrm{~S} \text { binding. }\end{array}$ & Mazna et al., 2008 \\
\hline P95A & 2.59 & $\mathrm{CHO}-\mathrm{K} 1$ & $\begin{array}{l}\text { No change in } K_{\mathrm{d}} \text { or } B_{\max } \text {. No change in } \mathrm{EC}_{50} \text { or } E_{\max } \text { for } \\
\text { melatonin or } 2 \text {-iodomelatonin stimulation of } \mathrm{GTP} \gamma^{35} \mathrm{~S} \text { binding. }\end{array}$ & Mazna et al., 2008 \\
\hline P158A & 4.40 & $\mathrm{CHO}-\mathrm{K} 1$ & $\begin{array}{l}\text { No change in } K_{\mathrm{d}} \text { or } B_{\max } \text {. No change in } \mathrm{EC}_{50} \text { or } E_{\max } \text { for } \\
\text { melatonin or } 2 \text {-iodomelatonin stimulation of } \mathrm{GTP}^{35} \mathrm{~S} \text { binding. }\end{array}$ & Mazna et al., 2008 \\
\hline $\mathrm{P} 174 \mathrm{~A}$ & 4.59 & $\mathrm{CHO}-\mathrm{K} 1$ & No specific binding. & Mazna et al., 2008 \\
\hline P174G & 4.59 & CHO-K1 & No specific binding. & Mazna et al., 2008 \\
\hline P212A & 5.50 & $\mathrm{CHO}-\mathrm{K} 1$ & $\begin{array}{l}\text { No change in } K_{\mathrm{d}} \text { or } B_{\max } \text {. Decreased } E_{\max } \text { for melatonin and 2- } \\
\text { iodomelatonin, stimulation of } \mathrm{GTP} \gamma^{35} \mathrm{~S} \text { binding. }\end{array}$ & Mazna et al., 2008 \\
\hline $\mathrm{P} 212 \mathrm{G}$ & 5.50 & $\mathrm{CHO}-\mathrm{K} 1$ & $\begin{array}{l}\text { No change in } K_{\mathrm{d}} \text { or } B_{\max } \text {. Increased } \mathrm{EC}_{50} \text { for } 2 \text {-iodomelatonin } \\
\text { stimulation of GTP } \gamma^{35} \mathrm{~S} \text { binding with no change in } E_{\mathrm{max}}\end{array}$ & Mazna et al., 2008 \\
\hline P266A & 6.50 & $\mathrm{CHO}-\mathrm{K} 1$ & No specific binding. & Mazna et al., 2008 \\
\hline P266G & 6.50 & $\mathrm{CHO}-\mathrm{K} 1$ & No specific binding. & Mazna et al., 2008 \\
\hline A305P & 7.50 & CHO-K1 & No specific binding. & Mazna et al., 2008 \\
\hline A305V & 7.50 & CHO-K1 & $\begin{array}{l}\text { No change for } K_{\mathrm{d}} \text { or } B_{\text {max }} \text {. Increased } \mathrm{EC}_{50} \text { for melatonin and } \\
\text { 2-iodomelatonin stimulation of } \mathrm{GTP} \gamma^{35} \mathrm{~S} \text { binding with } \\
\text { decreased } E_{\text {max }} \text {. }\end{array}$ & Mazna et al., 2008 \\
\hline \multicolumn{5}{|c|}{$\begin{array}{l}\text { HEK, human embryonic kidney; CHO, Chinese hamster ovary. } \\
{ }^{a} \text { Amino acid residues important for modulating binding to the } \mathrm{MT}_{1} \text { receptor (Farce et al., 2008). }\end{array}$} \\
\hline
\end{tabular}


ligand binding. Mazna et al. (2004) identified several amino acids in TM V (Val204), VI (Leu272), and VII (Tyr298) that are involved in melatonin interactions with the $\mathrm{MT}_{2}$ melatonin receptor binding pocket. In a subsequent studies, this group demonstrated that residues Asn268 and Ala275 in TM6 as well as residues Val291 and Leu295 in TM7 are essential for 2-iodomelatonin binding to the $\mathrm{hMT}_{2}$ receptor (Mazna et al., 2005). Mazna et al. (2008) assessed the impact of mutations on the $\mathrm{MT}_{2}$ melatonin receptor structure by molecular dynamic simulations of the receptors embedded in the fully hydrated phospholipid bilayer and demonstrated that residues Pro174, Pro212, and Pro266 are important for the ligand binding and/or signaling of this receptor (Table 3). Taken together, the identification of sequence specific motifs may ultimately provide the molecular basis for the rational design of type specific therapeutic compounds.

Farce et al. (2008) have published models showing the predicted binding site for melatonin on the $\mathrm{MT}_{1}$ and $\mathrm{MT}_{2}$ melatonin receptors based on site-directed mutagenesis analysis and a three-dimensional homology modeling of the receptors using bovine rhodopsin as a template (Fig. 5). In these models, the binding space for melatonin on the $\mathrm{MT}_{1}$ receptor seems to be relatively smaller than the space for the $\mathrm{MT}_{2}$ receptor. The conserved histidine of TM5 (His195 for $\mathrm{MT}_{1}$ and His208 for $\mathrm{MT}_{2}$ ), which is predicted to bind to the methoxy group, seem to be common to both receptor binding sites (Gerdin et al., 2003). The amine moiety interacts with Asn175 of TM4 in the $\mathrm{MT}_{2}$ receptor; however, a corresponding amino acid in the MT1 receptor TM3 is not an Asn; rather, serines (Ser110 and Ser114) seem to bind to melatonin (see Fig. 5; Farce et al., 2008).

\section{Cellular Signaling of $\mathrm{MT}_{1}$ and $\mathrm{MT}_{2}$ Melatonin Receptors}

The best-known signaling pathway for melatonin receptors is inhibition of cAMP formation via pertussis toxin-

\section{A $\mathrm{MT}_{1}$ Model}

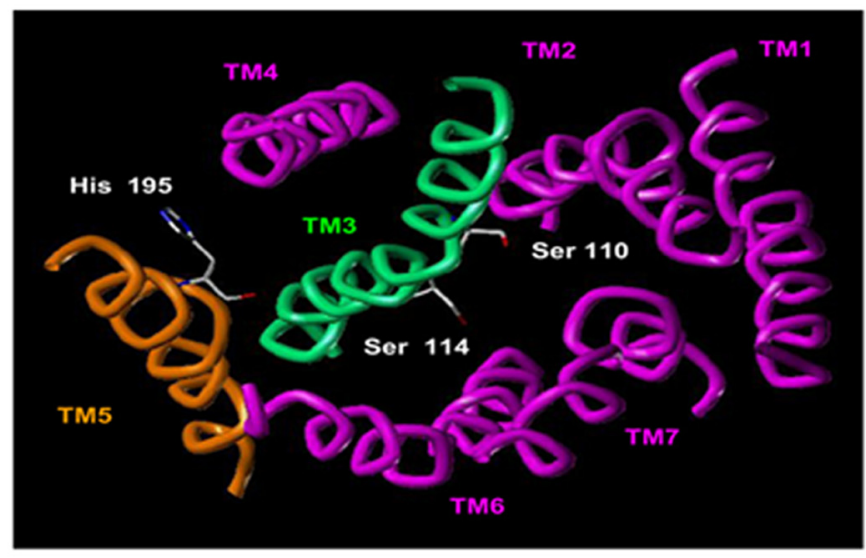

\section{B $\mathrm{MT}_{2}$ Model}

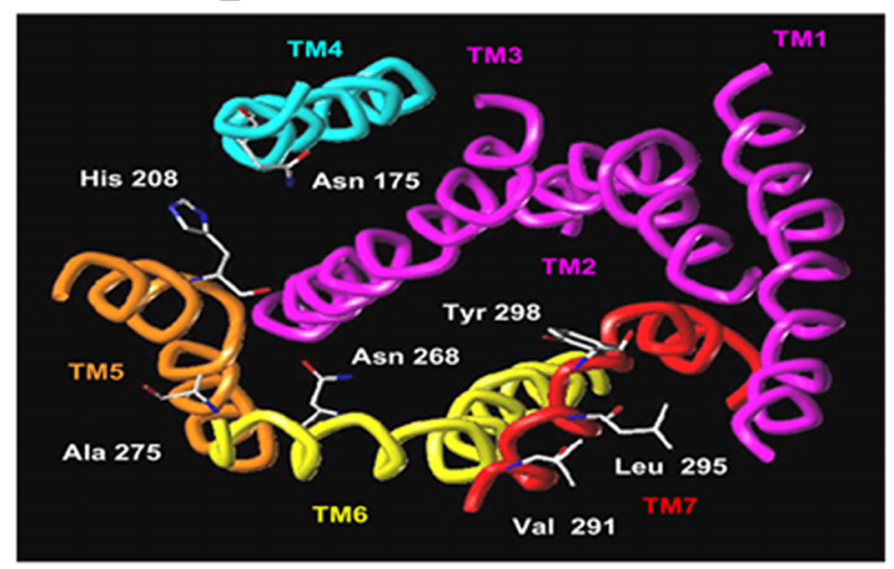

C $\mathrm{MT}_{1}$ Model

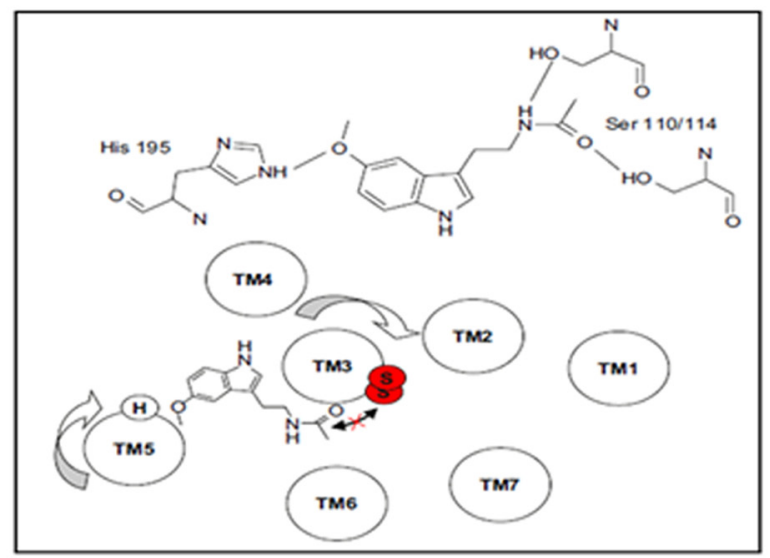

D $\mathrm{MT}_{2}$ Model

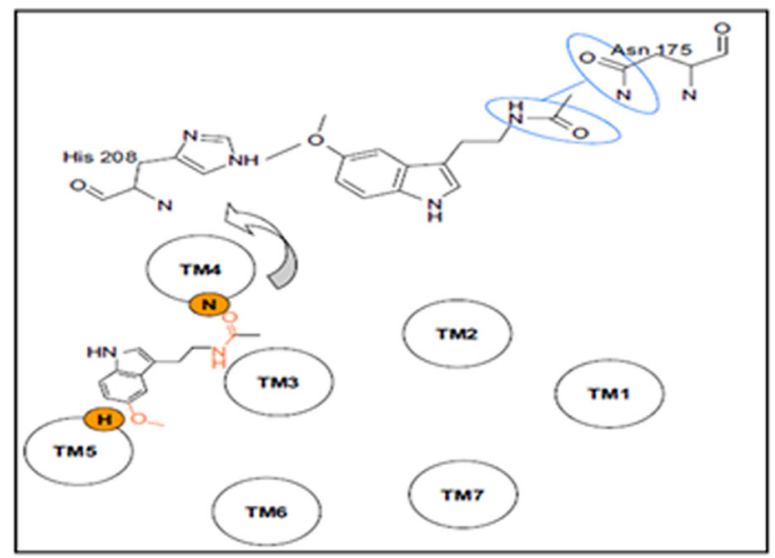

FIG. 5. $\mathrm{MT}_{1}$ and $\mathrm{MT}_{2}$ melatonin receptor 3 dimensional models and putative mode of binding for melatonin. A and $\mathrm{B}$ show critical amino acids residues for melatonin binding to the $\mathrm{MT}_{1}$ and $\mathrm{MT}_{2}$ melatonin receptors, respectively. The amino acids labeled in white have been defined by site-directed mutagenesis to modulate binding affinity (see Table 2 and 3). C and D show interactions among melatonin and key amino acid residues important for binding to the $\mathrm{MT}_{1}$ and $\mathrm{MT}_{2}$ melatonin receptors, respectively. [Adapted from Farce A, Chugunov AO, Logé C, Sabaouni A, Yous S, Dilly S, Renault N, Vergoten G, Efremov RG, Lesieur D, and Chavatte P (2008) Homology modelling of MT1 and MT2 receptors. Eur J Med Chem 43:1926-1944. Copyright (C) 2008 Elsevier Masson SAS. Used with permission.] 
sensitive G proteins. Although first described in frog melanophores (White et al., 1987), melatonin-mediated decreases in cAMP have been observed in a number of mammalian tissues, including pituitary, SCN, and cerebral arteries (Capsoni et al., 1994; Morgan et al., 1994b). Pertussis toxin (PTX) sensitivity indicates the involvement of $G$ proteins in the $G_{i} / G_{o}$ family; however, the identity of the specific $G$ proteins that transduce the melatonin signal in native tissues is not known. Using recombinant human receptors, adenylate cyclase inhibition has been confirmed as a signaling mechanism for both $\mathrm{MT}_{1}$ and $\mathrm{MT}_{2}$ melatonin receptor types (Reppert et al., 1995a). Recent studies, however, indicate that melatonin can elicit multiple recep- tor-mediated intracellular responses. Signal transduction mechanisms shown to be associated with $\mathrm{MT}_{1}$ and $\mathrm{MT}_{2}$ receptors are summarized below.

\section{A. $M T_{1}$ Melatonin Receptor Signaling}

$\mathrm{MT}_{1}$ melatonin receptors can couple to both PTXsensitive $\left(G_{i}\right)$ and insensitive $\left(G_{q / 11}\right) G$ proteins (Brydon et al., 1999b; Roka et al., 1999) (Fig. 6A). Activation of $\mathrm{MT}_{1}$ melatonin receptors decreases forskolin-stimulated cAMP formation (Reppert et al., 1994; Witt-Enderby and Dubocovich, 1996; Brydon et al., 1999a; Petit et al., 1999). Protein kinase A activity and phosphorylation of the cAMP responsive element-binding protein (CREB) (Witt-

\section{MELATONIN RECEPTOR SIGNALING}
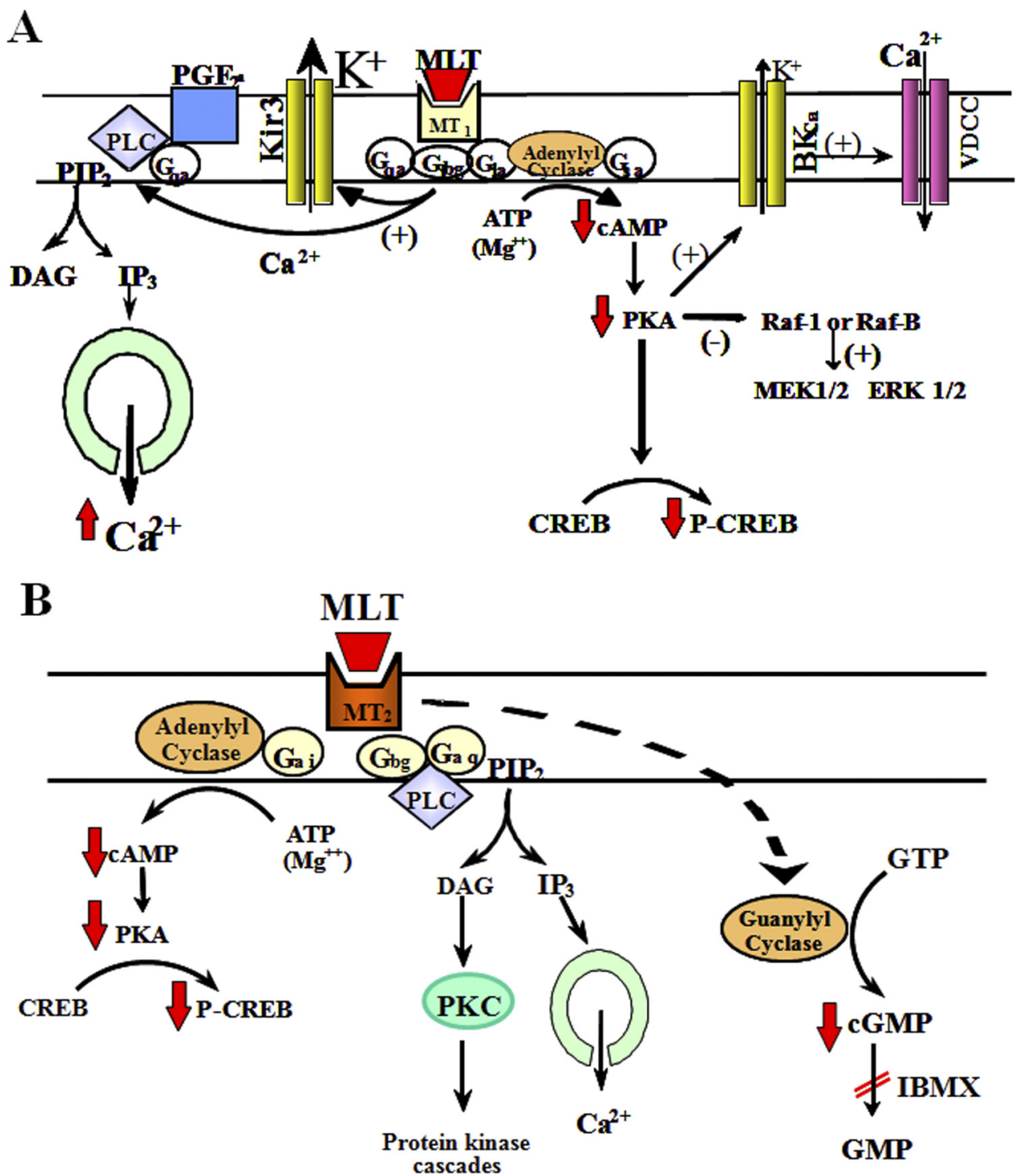

FIG. 6. $\mathrm{MT}_{1}$ and $\mathrm{MT}_{2}$ melatonin receptor signaling. A, melatonin (MLT) signals through activation of the MT 1 receptor via two parallel pathways

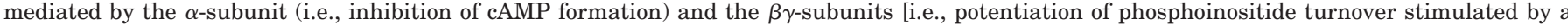

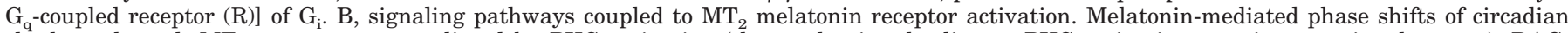

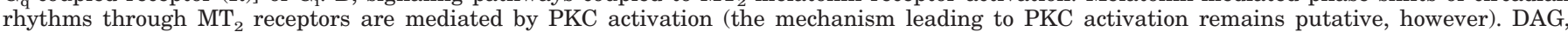

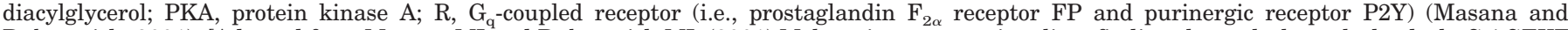

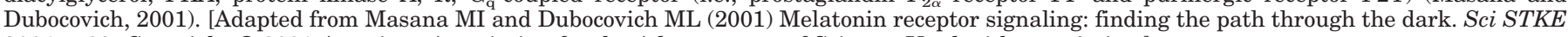
2001:pe39. Copyright (C) 2001 American Association for the Advancement of Science. Used with permission.] 
Enderby et al., 1998) are also inhibited. Some authors have also proposed that the $\beta \gamma$ subunit of a PTX-sensitive G protein may mediate the potentiation of phospholipase activation by prostaglandin $\mathrm{F}_{2 \alpha}$, leading to increase in phosphoinositide turnover (Godson and Reppert, 1997) or in ATP (Roka et al., 1999). In addition, the MEK1/2ERK1/2 pathway is stimulated by $\mathrm{MT}_{1}$ receptors in nonneuronal cells (Witt-Enderby et al., 2000; New et al., 2003; Radio et al., 2006).

$\mathrm{MT}_{1}$ melatonin receptors can also regulate ion fluxes and specific ion channels. Activation of endogenous $\mathrm{MT}_{1}$ receptors in ovine pars tuberalis cells increases intracellular calcium via PTX-insensitive G proteins (Brydon et al., 1999a) (Fig. 6A). In contrast, melatonin acts via PTX-sensitive $\mathrm{G}$ proteins to inhibit calcium influx in neonatal rat pituitary cells (Slanar et al., 2000) and in AtT20 cells expressing $\mathrm{MT}_{1}$ receptors (Nelson et al., 2001). Vasoconstriction seems to be mediated by decreases in cAMP-mediated phosphorylation of calciumactivated potassium channels $\left(\mathrm{BK}_{\mathrm{Ca}}\right)$ through $\mathrm{G}_{\mathrm{i}} / \mathrm{G}_{\mathrm{o}}$ proteincoupled $\mathrm{MT}_{1}$ melatonin receptors present in the smooth muscle, although participation of receptors localized in the endothelium cannot be ruled out (Nelson and Quayle, 1995; Geary et al., 1998; Masana et al., 2002). Conversely, melatonin transiently increases $\mathrm{BK}_{\mathrm{Ca}}$ channel activity in cultured rat myometrial cells (Steffens et al., 2003), an effect that can be blocked by PTX as well as by inhibition of protein kinase A activity. Inward-rectifier potassium channels (Kir) are also activated by melatonin. $\mathrm{MT}_{1}$ melatonin receptors expressed in X. laevis oocytes (Nelson et al., 1996) or AtT20 cells (Nelson et al., 2001) activate Kir3 inward-rectifier potassium channels through a PTX-sensitive mechanism that may involve $\beta \gamma$ subunits of $\mathrm{G}_{\mathrm{i}}$ proteins. Activation of Kir3 channels may underlie melatonin-mediated increases in potassium conductance (Jiang et al., 1995) and may be the mechanism by which melatonin inhibits neuronal firing in the SCN (Mason and Brooks, 1988; Shibata et al., 1989; Stehle et al., 1989). Hyperpolarization of neonatal pituitary cells may also be mediated by activation of $\mathrm{MT}_{1}$ melatonin receptors (Vanecek and Klein, 1992). Thus the data available indicate that activation of $\mathrm{MT}_{1}$ melatonin receptors elicits a variety of tissuedependent signaling responses.

\section{B. $M T_{2}$ Melatonin Receptor Signaling}

Recombinant $\mathrm{MT}_{2}$ melatonin receptors have also been shown to couple to inhibition of cAMP formation (Reppert et al., 1995a; Petit et al., 1999) (Fig. 6B). In addition, activation of $\mathrm{MT}_{2}$ melatonin receptors also can lead to inhibition of cGMP formation (Petit et al., 1999). In the SCN, melatonin increases PKC activity through activation of $\mathrm{MT}_{2}$ melatonin receptors, because this response is blocked by the selective $\mathrm{MT}_{2}$ receptor antagonist 4P-PDOT (Hunt et al., 2001). This finding suggests that $\mathrm{MT}_{2}$ melatonin receptors interact with the phospholipase C/diacylglycerol signaling pathway (McArthur et al., 1997). In the retina, $\mathrm{MT}_{2}$ melatonin receptors inhibit neurotransmitter release through a mechanism that probably involves intracel- lular calcium regulation (Dubocovich, 1995). Human myometrium from both pregnant and nonpregnant women expresses both $\mathrm{MT}_{1}$ and $\mathrm{MT}_{2}$ melatonin receptors (Schlabritz-Loutsevitch et al., 2003). In this study, 4P-PDOT blocked the melatonin-induced inhibition of cAMP signaling in cultured myometrial cells from nonpregnant women, suggesting the involvement of the $\mathrm{MT}_{2}$ melatonin receptor. Recent data confirmed the involvement of $\mathrm{MT}_{2}$ melatonin receptor in the action of melatonin on human myometrial smooth muscle cells and further demonstrated the involvement of $\mathrm{PKC}$ in $\mathrm{MT}_{2}$ melatonin receptor signaling (Sharkey and Olcese, 2007; Sharkey et al., 2009).

\section{Melatonin Receptor Regulation}

Regulation of signal transduction events is essential for maintaining timely and efficient cellular responses and homeostasis. Activation of GPCRs leads to changes in receptor sensitivity (desensitization, sensitization, internalization) and trafficking, leading to changes in ligand efficacy (Ferguson, 2001). The $\mathrm{MT}_{1}$ and $\mathrm{MT}_{2}$ melatonin receptors are differentially and distinctly regulated by physiological $(30-400 \mathrm{pM})$ and supraphysiological (1-1000 $\mathrm{nM})$ concentrations of melatonin. Physiological concentrations of nocturnal melatonin (100-400 pM) are already well above the potency $\left(\mathrm{EC}_{50}\right)$ for the melatonin receptors, which are activated by picomolar concentrations of melatonin (Reppert et al., 1996; Dubocovich et al., 1997). Daytime concentrations typically fall below $30 \mathrm{pM}$ and yet they can still induce activation and desensitization of melatonin receptors upon prolonged exposure to the hormone ( $\sim 8 \mathrm{~h}$ ) (Gerdin et al., 2004b). Blood melatonin levels after administration of an oral dose of 0.3 $\mathrm{mg}$ are similar to endogenous levels found in humans at night (Dollins et al., 1994). However, oral doses of melatonin or other ligands at $\geq 1 \mathrm{mg}$ may increase blood levels several times above the concentration necessary to activate melatonin receptors and therefore may alter receptor sensitivity (Dollins et al., 1994; Vachharajani et al., 2003; Mulchahey et al., 2004; Karim et al., 2006). $\mathrm{hMT}_{1}$ melatonin receptors expressed in heterologous mammalian cells show no observable changes in melatonin-receptor density, affinity, or functional sensitivity after exposure to physiological concentrations of melatonin for a period of time that mimics normal nocturnal exposure (i.e., $8 \mathrm{~h}$ ) (Gerdin et al., 2004b). By contrast, exposure to supraphysiological concentrations of melatonin (100 nM) increases $\mathrm{MT}_{1}$ receptor density and decreases receptor affinity, but there is no detectable internalization or loss of $\mathrm{MT}_{1}$ melatonin membrane receptors in $\mathrm{CHO}$ cells (MacKenzie et al., 2002; Gerdin et al., 2003, 2004b). In contrast, rapid arrestin-dependent internalization of the $\mathrm{MT}_{1}$ melatonin receptor was demonstrated in GT1-7 neurons after short-term exposure to melatonin (Roy et al., 2001). The GT1-7 cells express 
low levels of endogenous $\mathrm{MT}_{1}$ melatonin receptors and thus the presence of endogenous signaling partners different from those found in CHO and human embryonic kidney 293 cells and/or low level of constitutively active $\mathrm{MT}_{1}$ receptors may have facilitated $\mathrm{MT}_{1}$ melatonin receptor internalization (Dubocovich and Masana, 1998; Roka et al., 1999; Kokkola et al., 2007). Exposure to melatonin functionally desensitizes $\mathrm{MT}_{1}$ mediated inhibition of cAMP production (Hazlerigg et al., 1993; Witt-Enderby et al., 1998; Jones et al., 2000) and stimulation of PI hydrolysis (MacKenzie et al., 2002). At high concentrations, melatonin decreases cell proliferation and transformation via activation of either $\mathrm{hMT}_{1}$ or $\mathrm{hMT}_{2}$ receptors expressed in NIH-3T3 cells (Jones et al., 2000). Long-term treatment of rats with melatonin did not affect modulation of neuronal firing in the SCN mediated through activation of $\mathrm{MT}_{1}$ receptors (Ying et al., 1992). Thus, ligand alteration of $\mathrm{MT}_{1}$ receptor function may vary with ligand concentration and cell type, but this is an important consideration for understanding the consequences of rhythmically changing hormone levels as well as therapeutic dosing.

Exposure of human $\mathrm{MT}_{2}$ receptors in $\mathrm{CHO}$ cells to physiological concentrations of melatonin induced a concentration- and time-dependent receptor desensitization and internalization (Gerdin et al., 2004b). $\mathrm{MT}_{2}$ melatonin receptor recovery after melatonin-mediated desensitization/internalization is partially dependent on new protein synthesis. $\mathrm{MT}_{2}$ receptor resensitization after exposure to physiological levels of melatonin takes up to $8 \mathrm{~h}$, whereas exposure to supraphysiological concentrations of melatonin induced a more pronounced desensitization and slower recovery, taking up to $24 \mathrm{~h}$ to reach pre-exposure levels (Gerdin et al., 2004b). The relation between desensitization and/or internalization of $\mathrm{MT}_{1}$ and $\mathrm{MT}_{2}$ melatonin receptors by the circadian production of melatonin may promote changes in melatonin receptor function in the SCN. Melatonin via activation of $\mathrm{MT}_{2}$ receptors enhances differentiation in human adult mesenchymal stem cell osteoblasts (Radio et al., 2006). The reduction in $\mathrm{MT}_{2}$-mediated decreases in alkaline phosphatase enzyme activity occurs when $\mathrm{MT}_{2}$ receptors are fully desensitized, suggesting that decreases in receptor sensitivity is a necessary step in human adult mesenchymal stem cell differentiation into an osteoblast (Radio et al., 2006).

Given the potential involvement of $\mathrm{MT}_{1}$ and $\mathrm{MT}_{2}$ receptors in phase-shifting circadian rhythms in mammals, persistent desensitization of these receptors by supraphysiological levels of melatonin could affect circadian rhythmicity and sleep (Gerdin et al., 2004b; Wurtman, 2006). Phase advance of circadian rhythm of neuronal firing in the rat SCN brain slice by melatonin applied at circadian time (CT) 23 (CT12 is onset of activity in nocturnal animals)] is mediated through activation of $\mathrm{MT}_{2}$ receptors, which are functionally desensitized by exposure to physiological levels of melatonin $(300 \mathrm{pM})$ for a length of time mimicking the nocturnal surge $(8 \mathrm{~h})$. Concurrent ex- posure of the SCN brain slice to both melatonin and the $\mathrm{MT}_{2}$ antagonist 4P-PDOT blocks the functional desensitization of $\mathrm{MT}_{2}$ receptors (Gerdin et al., 2004b). Together these results suggest that although both the $\mathrm{MT}_{1}$ and $\mathrm{MT}_{2}$ receptors can be desensitized by exposure to melatonin, the receptors are differentially regulated depending on melatonin concentration (physiological versus supraphysiological), time of exposure (e.g., short versus long), cellular background (Audinot et al., 2003), and receptor state (quiescent versus constitutive) (Roy et al., 2001; Gerdin et al., 2004a,b; Kokkola et al., 2007).

\section{IV. $\mathrm{MT}_{1}$ and $\mathrm{MT}_{2}$ Melatonin Receptors: Structure-Activity Relationships and Selective Ligands}

\section{A. Ligand Selectivity}

Advances in medicinal chemistry led to the discovery of new molecules that are specific and selective ligands for melatonin receptors (Fig. 7A). $\mathrm{MT}_{1}$ and $\mathrm{MT}_{2}$ melatonin receptors show picomolar affinity for the radioligand $2-\left[{ }^{125} \mathrm{I}\right]$ iodomelatonin and are characterized by the following general rank order of pharmacological affinities: 2-iodomelatonin $\geq$ melatonin $\gg N$-acetylserotonin $\gg$ serotonin, reported for COS-7 cells transiently transfected (Dubocovich et al., 1997) or NIH-3T3 (Nonno et al., 1999) and CHO cells (Browning et al., 2000) stably expressing the recombinant $\mathrm{hMT}_{1}$ and $\mathrm{hMT}_{2}$ receptors (Fig. 7, B and C). 2-Iodomelatonin and ramelteon show between 3 and 10 times higher affinity than melatonin on the $\mathrm{MT}_{1}$ receptor, but both have similar affinity to melatonin on the $\mathrm{MT}_{2}$ receptor (Dubocovich et al., 1997; Kato et al., 2005). Conversely, melatonin and 6-chloromelatonin have similar affinity on the $\mathrm{MT}_{2}$ melatonin receptor, whereas on the $\mathrm{MT}_{1}$ receptor, 6-chloromelatonin has 10 to 20 times lower affinity than melatonin (Dubocovich et al., 1997; Browning et al., 2000). However, ligands need approximately 50 to 100 times higher affinity/potency for one receptor type relative to the other to be considered selective (Dubocovich et al., 2000). By these criteria, melatonin analogs have been developed that show distinct selectivity for either the $\mathrm{MT}_{1}$ or $\mathrm{MT}_{2}$ melatonin receptor types and are discussed below, along with known structure-activity relationships.

\section{B. Structure-Activity Relationships}

The discovery of ligands selective for melatonin receptor types has been hindered by the low receptor density and heterogeneity of receptor types in native tissues and by the relatively few dependable models available in which a functional response can be ascribed to one receptor type. However, much has been learned about the structural features of the melatonin molecule that are necessary for binding and activation of its receptor. More recently with the wider use of cells expressing recombinant $\mathrm{hMT}_{1}$ and $\mathrm{hMT}_{2}$ receptor types, progress has been made toward developing receptor type-selec- 
A

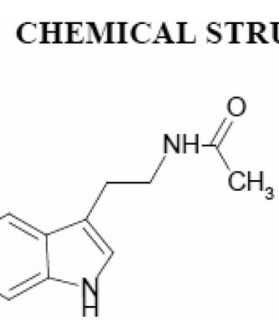

Melatonin<smiles>CC(=O)NCCc1c[nH]c2ccc(OCCO)cc12</smiles>

5-HEAT<smiles>COc1ccc2[nH]cc(CCN3CCCC3=O)c2c1</smiles>

GR 135533<smiles>COc1ccc2cccc(CCNC(C)=O)c2c1</smiles>
S 20098<smiles>CCc1ccc2scc(CCNC(C)=O)c2c1</smiles>

S 22153<smiles>COc1ccc2[nH]c(I)c(CCNC(C)=O)c2c1</smiles>

2-Iodomelatonin<smiles>CC(=O)NCCc1c(Cc2ccccc2)[nH]c2ccccc12</smiles>

Luzindole<smiles>CCC(=O)NCCc1c(Cc2ccccc2)[nH]c2ccccc12</smiles>

N 0889<smiles>O=C(NCCc1cccc2ccccc12)C1CCC1</smiles>

S 20928

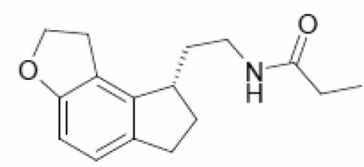

Ramelteon

(TAK-375)<smiles>COc1cc2c(CCNC(C)=O)c[nH]c2cc1Cl</smiles>

6-Chloromelatonin<smiles>COc1cc2c(C(C)CNC(C)=O)c[nH]c2cc1Cl</smiles>

LY 156735<smiles>COc1ccc2c(c1)c1c(n2C)CCC[C@H]1CNC(C)=O</smiles>

AMMTC<smiles>CC(=O)NCCN1CCc2ccc3c(c21)CCO3</smiles>

GR 196429<smiles>COc1ccc2c(c1)[C@H](N1CCN(C(=O)C3CC3)CC1)CC2</smiles>

Compound 11

FIG. 7. Chemical structure of melatonin receptor ligands. A, chemical structures of nonselective $\mathrm{MT}_{1} / \mathrm{MT}_{2}$ ligands.

tive ligands. Early studies of structure-activity relationships were drawn from data obtained in native tissues. Here we will first briefly review studies carried out in native tissues and thereafter will summarize structureactivity relationships in recombinant systems (Table 4).

Melatonin has no ionizable groups at physiological $\mathrm{pH}$ and is a lipophilic molecule readily able to cross the plasma membrane. Evidence suggests that the $\mathrm{N}$-acetyl and 5-methoxy groups of melatonin are important for both receptor binding and activation. Removal of either $N$-acetyl or 5-methoxy groups leads to a dramatic reduction in $2-\left[{ }^{125} \mathrm{I}\right]$ iodomelatonin binding affinity (Dubocovich and Takahashi, 1987; Sugden et al., 1997), whereas 5-hydroxytryptamine (i.e., loss of 


\section{B CHEMICAL STRUCTURES OF SELECTIVE MT 1 MELATONIN RECEPTOR LIGANDS}

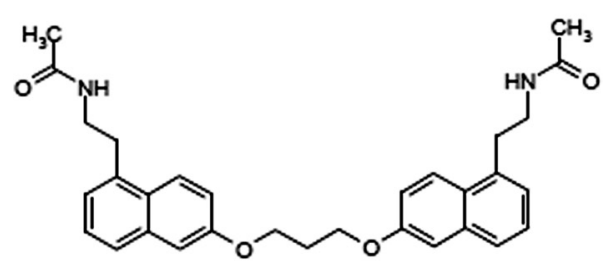

S26131<smiles>CCCCCCOc1ccc2c(c1)C(CCNC(C)=O)CCO2</smiles>

$\$ 25567$

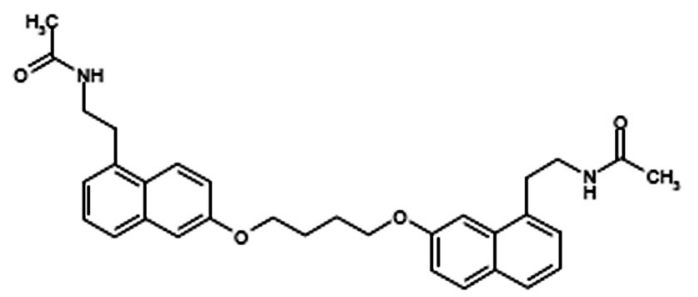

S 26284

FIG. 7. Continued. B, chemical structures of selective $\mathrm{MT}_{1}$ melatonin receptor ligands.

both $N$-acetyl and 5-methoxy groups) does not bind to melatonin receptors. Analogs with $N$-acyl groups larger than $N$-acetyl often show improved binding affinity and agonist potency.

A number of general principles have been discovered that apply to both melatonin receptors. The 5-position on the indole ring is optimal for the methoxy group, because moving it to position 4,6 , or 7 leads to a dramatic loss of affinity, although compounds with a halogen at the 5-position do retain high affinity (Mor et al., 1998). The relative position of the methoxy group and the $N$-acetylaminoethyl side chain seems to be an important determinant of affinity (Depreux et al., 1994; Langlois et al., 1995; Garratt et al., 1996). The indole ring is not essential for ligand binding because it can be replaced by various other aromatic systems such as naphthalene, benzofuran, benzothiophene, or benzocycloalkene rings (Depreux et al., 1994; Leclerc et al., 1998; Fukatsu et al., 2002). If methoxy and $N$-acylaminoethyl groups are positioned appropriately on these aromatic scaffolds, ligands with high affinity can result. Although one role of the indole nucleus is to hold the important functional groups in the proper positions, it may also play a role in ligand binding. A number of analogs with substitutions in positions 2 and 6 of melatonin (or the analogous position of ligands based on other aromatic ring systems) have been made. Substitution of a methyl, phenyl, or halogen at position 2 of melatonin can increase receptor affinity by up to 10 -fold (Spadoni et al., 1993; Garratt et al., 1994a,b, 1995), and combination of an optimal $N$-acyl group with a 2 -halogen substitution gives ligands with extraordinarily high affinity (e.g., 2 -iodo- $N$-butanoyl-5-methoxytryptamine, $\mathrm{p} K_{\mathrm{i}}$ 10.8) (Sugden and Rowe, 1994). One effect of the 2-po- sition substituent seems likely to be to "push" the $\mathrm{N}$-acetylaminoethyl side chain into the preferred conformation for interaction with the receptor. In addition, there is evidence that substituents in the C-2 position can interact directly with the receptor, leading to increased ligand affinity (Mathé-Allainmat et al., 1996; Spadoni et al., 1997). In vivo melatonin is degraded rapidly, primarily in the liver by 6-hydroxylation followed by conjugation and excretion in the urine. Some 6-position analogs have been synthesized with the aim of retarding metabolism (Clemens and Flaugh, 1986). A halogen substituent at the 6-position reduces affinity only slightly, whereas the affinity of 6 -hydroxymelatonin is reduced by only 5 - to 10 -fold, and 6 -methoxymelatonin by more than 100 -fold (Sugden et al., 1995).

Melatonin is a rather flexible molecule with a number of bonds around which rotation is possible. The conformation melatonin adopts when interacting with its receptors has been debated. Evidence from conformationally constrained and stereoselective analogs (Jansen et al., 1996; Beresford et al., 1998; Davies et al., 1998; Leclerc et al., 1998; Jellimann et al., 2000) has provided information on the orientation likely to be adopted by the 5 -methoxy and $N$-acetylaminoethyl groups when interacting with the receptor. Some of these ligands [(-)- and (+)-AMMTC] have been used as tools in experiments designed to determine whether a biological response is really mediated by melatonin receptor activation (Ting et al., 1997). Others have aided the development of receptor models of the interactions between ligand and receptor (Mor et al., 1999), and continue to guide the synthesis of novel melatonin receptor analogs. 
C<smiles>COc1ccc2[nH]c(Cc3ccccc3)c(CCNC(C)=O)c2c1</smiles>

5-Methoxyluzindole<smiles>CCCCC(=O)NCCc1c(Cc2ccccc2)[nH]c2ccccc12</smiles>

DH 97<smiles>COc1ccc2c(c1)[C@H](CCCC(=O)C1CCCC1)C[C@@H](c1ccccc1)C2</smiles>

S 28407<smiles>CCC(=O)NCc1cc2c(OC)cccc2n1Cc1ccc(Cl)cc1</smiles><smiles>CC(=O)NCCc1c(Cc2ccc(C)cc2)[nH]c2ccccc12</smiles>

N 0891<smiles>COc1ccc2[nH]cc(C3CCCN(C(C)=O)C3)c2c1</smiles>

GR 128107<smiles>COc1ccc2cc(-c3cccc(N)c3)cc(CCNC(C)=O)c2c1</smiles>

S 24773<smiles>CCCC(=O)NCCc1c2n(c3ccc(OC)cc13)CCCc1ccccc1-2</smiles><smiles>CCC(=O)NC1Cc2ccccc2C(c2ccccc2)C1</smiles>

4P-PDOT<smiles>COc1cccc(Cc2oc3ccc(OC)cc3c2CCNC(C)=O)c1</smiles>

S 24014<smiles>CCNC(=O)N1CCN([C@@H]2CCc3ccc(OC)cc32)CC1</smiles>

FIG. 7. Continued. C, chemical structures of selective $\mathrm{MT}_{2}$ melatonin receptor ligands. Chemical names (see also the abbreviations list at the bottom of the first page of the article): compound 11, 1-(cyclopropylcarbonyl)-4-[(1R)-6-methoxy-2,3-hidro-1H-inden-1-yl]piperazine; compound $12, N$-[(1-p-chlorobenzyl-4-methoxy- $1 H$-indol-2-yl)methyl]propanamide; compound $13,(R)$-4-(2.3-dihydro-6-methoxy-1H-inden-1-yl)- $N$-ethyl-1piperazine carboxamide; DH 97, $N$-pentanoyl-2-benzyltryptamine; GR 128107, 3-(1-acetyl-3-piperidinyl)-5-methoxyindole; GR 135533, 3-( $N$ ethyl-2-pyrrolidinone)5-methoxyindole; GR 196429, $N$-(2-[2,3,7,8-tetrahydro-1H-furo\{2,3-g\}indol-1-yl]ethyl)acetamide; IIK7, $N$-butanoyl-2-(2methoxy-6H-isoindolo [2,1-a]indol-11-yl)ethanamine; K185, N-butanoyl-2-(5,6,7-trihydro-11-methoxybenzo[3,4]cyclohept[2,1-a]indol-13-yl) ethanamine; luzindole, 2-benzyl- $N$-acetyltryptamine; LY 156735, $\mathrm{N}$-[2-(6-chloro-5-methoxy-1H-indol-3-yl)propyl]acetamide; $\mathrm{N}$ 0889, 2-benzyl$N$-propionyl-acetyltryptamine; N 0891, 2-( -methyl-benzyl)- $N$-acetyltryptamine; S 20098, $N$-(2-[7-methoxy-1-naphthalenyl]ethyl)acetamide; S 20928, $N$-[2-naphth-1-yl-ethyl]-cyclobutyl carboxamide; S 22153, $N$-[2-(5-ethylbenzo[b]thiophen-3-yl)ethyl]acetamide; S 24014, $N$-[2-(2-(3methoxybenzyl)5-methoxy benzo(b)furan-3-yl)ethyl]acetamide; S 24635, $N$-[2-(5-carbamoylbenzofuran-3-yl)ethyl]acetamide; S 24773, $N$-\{2-[3(3-aminophenyl)-7-methoxy-1-naphthyl] ethyl\}acetamide; S 25726, N-methyl-(3-\{2-[(cyclopropylcarbonyl)amino] ethyl\}benzo[b]furan-5yl)carbamate; S 25567, $(R, S)-N$-[2-(6-hexyloxy-3,4 dihydro-2H-1-benzopyran-4-yl)ethyl]acetamide; S 26131, $N$-(2-\{7-[3-(\{8-[2-acetylamino) ethyl]-2-naphtyl\}oxy)propoxy]-1-naphthyl\}ethyl)acetamide; S 26284, N-(2-\{7-[4-(\{8-[2-acetylamino)ethyl]-2-naphtyl\}oxy)butoxy]-1naphthyl\}ethyl)acetamide; S 26553, N-methyl-1\{1-[2-(acetylamino)ethyl]naphthalen-7-yl\}carbamate; S 27533, N-[2-(5-methoxy-1-methyl-4nitroindol-3-yl)ethyl]acetamide; S 28407, $N$-[2-(7-methoxy-3-phenyl-1,2,3,4-tetrahydronaphthalen-1-yl)ethyl]cyclobutyl carboxamide; TAK-375, (S)- $N$-[2-(1,6,7,8-tetrahydro-2H-indeno[5,4-b]furan-8-yl)-ethyl]propionamide. 


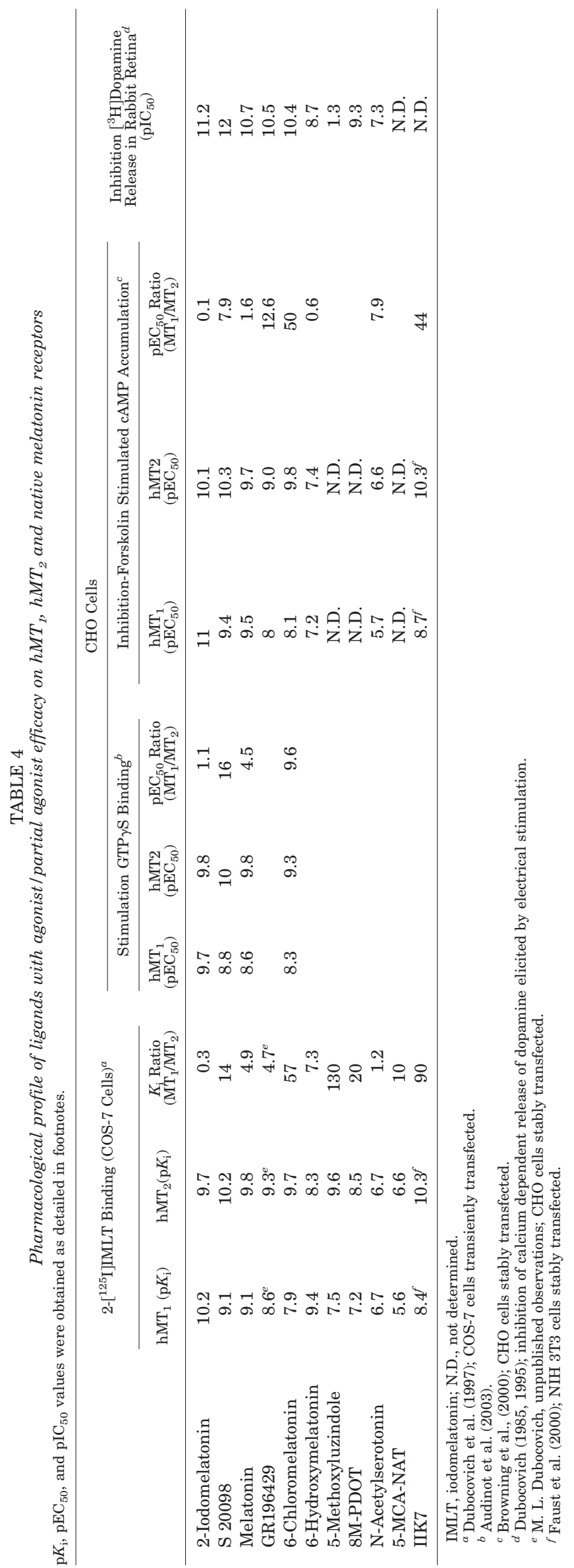

\section{Selective $M T_{1}$ and $M T_{2}$ Melatonin Ligands}

Although many of the melatonin receptor ligands that have been synthesized have little receptor selectivity between $\mathrm{MT}_{1}$ and $\mathrm{MT}_{2}$, some progress has been made in delineating differences in the structure-activity relationships of the melatonin receptor types. Substitution of the 2-position with a benzyl group on the indole nucleus has an influence on selectivity. Indeed, luzindole was the first ligand reported to have a higher affinity for the $\mathrm{MT}_{2}$ type and its substituted analogs. N 0891, 5-methoxyluzindole, and $\mathrm{DH} 97$ are $\mathrm{MT}_{2}$-selective (Dubocovich et al., 1997; Teh and Sugden, 1998) (see Fig. 1 for full chemical names of all numbered compounds mentioned herein). A substitution with a phenyl group on 2-acetamidotetralin analogs led to one of the most $\mathrm{MT}_{2}$ selective ligands, 4P-PDOT with $\mathrm{p} K_{\mathrm{i}}$ of 6.3 for $\mathrm{hMT}_{1}$ and $\mathrm{p} K_{\mathrm{i}}$ of 8.8 for $\mathrm{MT}_{2}$ (Dubocovich et al., 1997). Within a series of analogs in which a 2-phenyl group was attached at the ortho position to the indole $N$ - by 1,2 , or 3 methylene groups, several $\mathrm{MT}_{2}$-selective analogs (IIK7, K185) were identified (Sugden et al., 1999; Faust et al., 2000) indicating that the changes in ring size engendered by the $N$-indole-2-phenyl bridge were more readily accommodated by the $\mathrm{MT}_{2}$ site. These results have led to the first structure-affinity relationship for $\mathrm{MT}_{2}$ selectivity. An additional pocket at the $\mathrm{MT}_{2}$ receptor should be present and positioned out of the plane of the aromatic nucleus of melatonin, which would not be present at the $\mathrm{MT}_{1}$ receptor. This hypothesis is supported by a threedimensional quantitative structure-activity relationship comparative molecular field analysis and statistical analysis (Rivara et al., 2003). Binding studies performed on the cloned receptors confirmed the $\mathrm{MT}_{2}$ selectivity. Other publications (Wallez et al., 2002; Audinot et al., 2003; Yous et al., 2003) reported selective $\mathrm{MT}_{2}$ ligands with a benzyl substituent in the 2-position of benzofuran bioisosters ( $S$ 24014) or a phenyl substituent in the 3-position of tetrahydronaphthalenic (S 28407) or naphthalenic (S 24773) bioisosteres. Following the same rationale, Spadoni et al. (2001) synthesized some melatonin derivatives, 2-acylaminoalkylindoles with a substitution by a benzyl in the 1-position (compound 12), that are selective for the $\mathrm{MT}_{2}$ receptor type. Two other selective $\mathrm{MT}_{2}$ ligands have been reported with rigidification of the side chain of melatonin with a piperidine amide chain (GR 128107) or piperazine amide chain (compound 13) (Dubocovich et al., 1997; Mattson et al., 2003). The structure-affinity relationships for $\mathrm{MT}_{2}$ selectivity have not been explored in these series. Most $\mathrm{MT}_{2}$ receptor-selective ligands are either antagonists or partial agonists.

The first selective $\mathrm{MT}_{1}$ ligands were described in 2003. Their main structural feature is the presence of a bulky substituent instead of the methoxy group in the 5 -position. All of them except one are dimeric derivatives in which two molecules of S 20098, the naphthalenic 
analog of melatonin, are linked together through their methoxy substituent by a polymethylene side chain (Descamps-François et al., 2003). The number of methylene groups in the linking chain varied from 2 to 8; the highest selectivity ratio was for three methylene groups (S 26131). These alterations in selectivity decrease the affinity for the $\mathrm{MT}_{2}$ type. Only one analog has been examined in a functional assay and was shown to be an antagonist with $\sim 30$ - to 40 -fold $\mathrm{MT}_{1}$ selectivity. The only other selective ligand described (S 25567), which is not a dimeric derivative, bears a long alkoxy side chain at the 6-position of a benzopyran analog (Audinot et al., 2003). These $\mathrm{MT}_{1}$-selective ligands are antagonists or partial agonists.

\section{Ligand Efficacy in Native Tissues}

This section focuses only on ligands for which efficacy has been reported for native mammalian melatonin receptors either in vivo or in vitro. (Dubocovich et al., 1997; Mattson et al., 2003).

1. Agonists. No selective $\mathrm{MT}_{1}$ melatonin receptor agonist has been reported to date. Compound $13[(R)$ 4-(2,3-dihydro-6-methoxy- $1 H$-inden-1-yl)- $N$-ethyl-1piperazine-carboxamidefumarate] is an agonist with selectivity for $\mathrm{MT}_{2}$ melatonin receptors $\left(\mathrm{hMT} / \mathrm{hMT}_{2}\right.$ affinity ratio $=117$ ). Mattson et al. (2003) reported that Compound 13 had lower vasoconstrictor efficacy in rat caudal arteries compared with an equimolar concentration of melatonin. Compound 13 was also found to phase advance the circadian running-wheel activity of rats when given at dose of 1 to $56 \mathrm{mg} / \mathrm{kg}$. However, in vivo receptor selectivity is difficult to attain because of the high affinity of melatonin ligands and the need to administer these ligands at very low doses. Even when agonists show some selectivity in in vitro assays, a low dose in vivo may activate both $\mathrm{MT}_{1}$ and $\mathrm{MT}_{2}$ receptors (see further discussion under section V.B.1).

2. Antagonists/Partial Agonists. A number of antagonists/partial agonists have been identified using native tissues, and several show selectivity for $\mathrm{MT}_{2}$ receptors. Structural modifications of melatonin or melatonin bioisosteres that seem to predispose to antagonist action include removal of the 5-methoxy group (e.g., luzindole, 2-benzyl $N$-acetyltryptamine) and the 4-phenyl substituted tetralines (e.g., 4PPDOT), or the naphthalenic bioisostere (e.g., S 20928) (Dubocovich et al., 1997; Conway et al., 2000; Audinot et al., 2003). Luzindole was the first ligand described as a competitive melatonin receptor antagonist (Dubocovich, 1988a), and it has been used extensively in the field to validate melatonin receptor action, although it is relatively nonselective of receptor type $\left(\mathrm{MT}_{1} / \mathrm{MT}_{2}\right.$ affinity ratio $=16-26$ ). Luzindole was the first antagonist used to demonstrate the presence of melatonin receptors mediating inhibition of dopamine release in rabbit retina (Dubocovich, 1988a; Dubocovich et al.,
1997) and the phase shift of circadian rhythms in the rodent SCN (Dubocovich, 1988a; Hunt et al., 2001). S 20928, which also behaves as an antagonist in the rat SCN (Ying et al., 1996), was used to demonstrate that the duration of melatonin-receptor exposure per day determines the onset of seasonal obesity in garden dormice (Le Gouic et al., 1996). The replacement of the 5-methoxy group by an ethyl group that prevents hydrogen bonding with the receptor led to the benzothiophene antagonist S 22153 (Audinot et al., 2003). This nonselective melatonin antagonist is able to block the phase advancing effect of melatonin on running-wheel activity in mice (Weibel et al., 1999) and the anxiolytic-like properties of melatonin (Kopp et al., 1999). Moreover, in Syrian hamster, S 22153 implants dissociate different aspects of the photoperiodic responses (Pitrosky et al., 2003) (Table 5).

4P-PDOT was the first available selective $\mathrm{MT}_{2}$ melatonin receptor antagonist and it has been used in many studies as a pharmacological tool to demonstrate the involvement of the $\mathrm{MT}_{2}$ receptor type in physiological function. In particular, it has been used to demonstrate the involvement of $\mathrm{MT}_{2}$ receptors in mediating phase advances of circadian rhythm of neuronal firing in the SCN circadian clock (Dubocovich et al., 1998a; Hunt et al., 2001) and in inhibiting dopamine release in retina (Dubocovich et al., 1997). Among the other selective $\mathrm{MT}_{2}$ ligands described, the activity on native mammalian tissues has been evaluated only for GR 128107, in which the secondary amide of the $N$-ethylamino side chain has been replaced with a constrained tertiary amide (Dubocovich et al., 1997). GR 128107 was reported to antagonize melatonin-induced inhibition of dopamine released from rabbit retina (Dubocovich et al., 1997). There are no published data available regarding $\mathrm{MT}_{1}$ selective antagonists on native tissues.

Whereas luzindole and 4P-PDOT are competitive antagonists in native tissues, their pharmacological effects are complex in recombinant system and non-neuronal tissues. 4P-PDOT and its congener 4P-ADOT are neutral antagonists in native tissues that express a low density of melatonin receptors (Dubocovich et al., 1997, 1998a).

4P-PDOT was shown to act as a partial agonist/agonist on the inhibition of leukocyte rolling in the microcirculation (Lotufo et al., 2001) and in recombinant systems (Nonno et al., 1999; Browning et al., 2000). Moreover, it was shown using recombinant systems that the affinity ratios of $4 \mathrm{P}-\mathrm{PDOT}\left(\mathrm{MT}_{1} / \mathrm{MT}_{2}: 66-22,000\right)$ can vary depending on the level of receptor expression or signaling pathways in each recombinant system (Dubocovich et al., 1997; Dubocovich and Masana, 1998; Nonno et al., 1999; Browning et al., 2000; Audinot et al., 2003). Results obtained with these and other less characterized ligands should be interpreted with caution, because doses used in vivo may lead to blood levels that block both $\mathrm{MT}_{1}$ and $\mathrm{MT}_{2}$ receptors (Dubocovich et al., 1998). 
TABLE 5

Pharmacological profile of partial agonists/antagonists on $h M T_{1}, h M T_{2}$, and native melatonin receptors All values are from Dubocovich et al. (1997) except as noted otherwise.

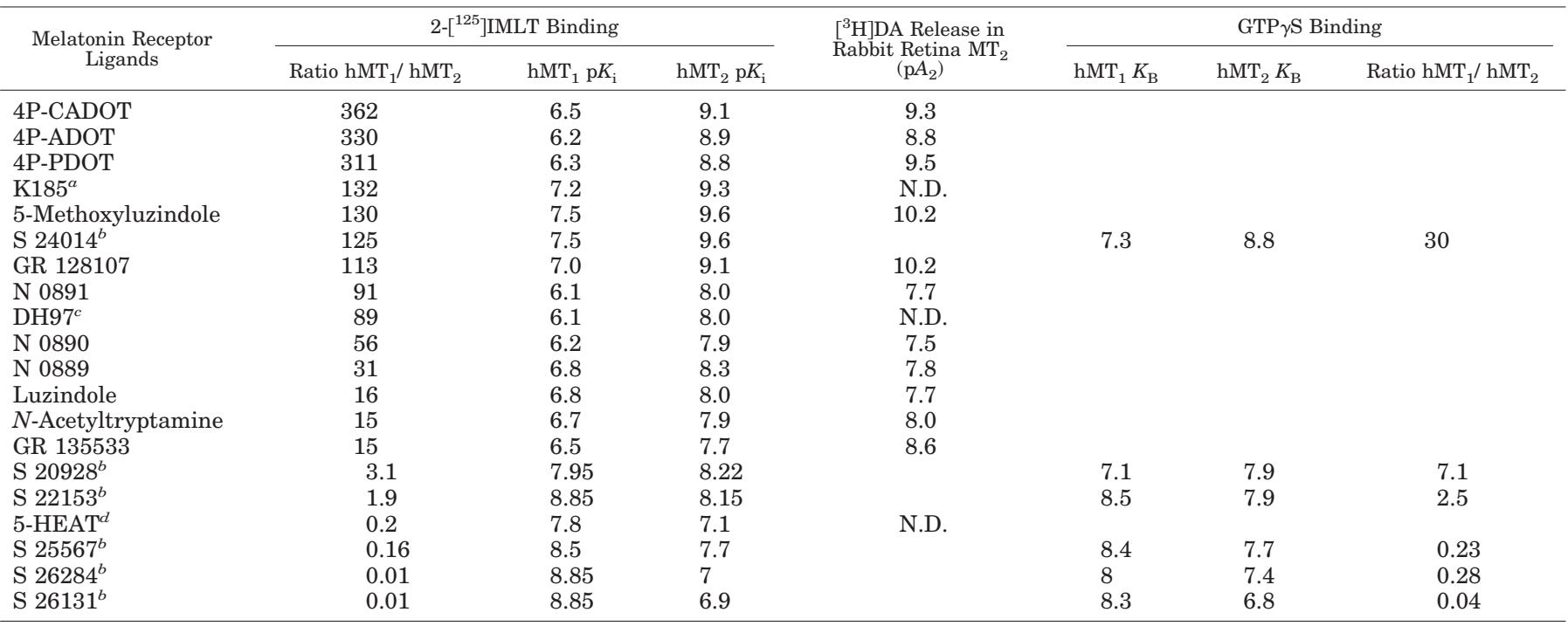

IMLT, iodomelatonin; DA, dopamine; 4P-CADOT, 4-phenyl-2-chloro-acetamidotetraline; N.D., not determined; 5-HEAT, 5-hydroxyethoxy- $N$-acetyltryptamine,

${ }^{a}$ Values from Faust et al., 2000.

${ }^{b}$ Audinot et al., 2003.

${ }^{c}$ Teh and Sugden, 1999.

${ }^{d}$ Nonno et al., 2000.

3. Inverse Agonists. Recombinant $\mathrm{MT}_{1}$ melatonin receptors expressed at physiologically relevant levels are capable of constitutive activity, producing spontaneous regulation of effectors in the absence of agonist activation (Roka et al., 1999). Inverse agonists stabilize the free/uncoupled form of the receptor and are used to detect constitutive activity by reducing agonist-independent receptor activity (Browning et al., 2000). In this regard, a few of the melatonin ligands described above were also shown to reduce agonist-independent $\mathrm{MT}_{1}$ melatonin receptor activity. As inverse agonists, luzindole and 4P-PDOT have higher apparent affinity for the $\mathrm{hMT}_{1}$ melatonin receptor in the presence of GTP (Dubocovich and Masana, 1998), decreasing basal guanosine $5^{\prime}-O-\left(3-\left[{ }^{35} \mathrm{~S}\right]\right.$ thio)triphosphate binding (Glaser et al., 1998) and increasing cAMP formation (Browning et al., 2000 ) in CHO cells expressing the $\mathrm{hMT}_{1}$ receptor at high density.

4. Dimers/Heterodimers. The three members of the melatonin receptor gene family expressed in humans, $\mathrm{MT}_{1}, \mathrm{MT}_{2}$, and related orphan receptor GPR50, have been shown to dimerize in transfected human embryonic kidney 293 cells (Levoye et al., 2006b). It is noteworthy that these proteins not only self-associate to form stable homodimers but can also form heterodimers in cells coexpressing various gene products (Ayoub et al., 2002, 2004; Levoye et al., 2006a). Several lines of evidence indicate that the formation of melatonin receptor heterodimers may also have a pronounced impact on receptor function. A modified pharmacological profile has been observed for $\mathrm{MT}_{1} / \mathrm{MT}_{2}$ heterodimers compared with the corresponding homodimers (Ayoub et al., 2004). The propensity of $\mathrm{MT}_{1} / \mathrm{MT}_{2}$ heterodimer formation is similar to or even higher than that of the corresponding homodimers. Both the $\mathrm{MT}_{1}$ and $\mathrm{MT}_{2}$ binding sites are functional within the heterodimer. The two binding sites within the heterodimer maintain their respective selectivity for $\mathrm{MT}_{1}$ - and $\mathrm{MT}_{2}$-selective ligands. Furthermore, the ligand-interaction profile of the $\mathrm{MT}_{1} / \mathrm{MT}_{2}$ heterodimer determined is distinct from that of the $\mathrm{MT}_{2}$ homodimer. Although further studies will be necessary to firmly establish the existence of such complexes in tissues and their physiological relevance, the existence of such complexes may be anticipated. A widespread coexpression of melatonin receptors in several tissues such as the retina and different regions of brain has indeed been reported by several groups (Dubocovich, 1983; Reppert et al., 1994; Dubocovich et al., 1998a; Savaskan et al., 2002a,b, 2005; Wu et al., 2007). Engagement of $\mathrm{MT}_{1}$ into heterodimers with the orphan GPR50 completely abolished melatonin binding to $\mathrm{MT}_{1}$ and coupling of this receptor to $\mathrm{G}_{\mathrm{i}}$ proteins and $\beta$-arrestins (Levoye et al., 2006a). This may represent an interesting regulatory mechanism for melatonin function (Jockers et al., 2008).

\section{V. $\mathrm{MT}_{1^{-}}$and $\mathrm{MT}_{2}$-Mediated Functional Responses}

The identification of functional responses mediated by $\mathrm{MT}_{1}$ melatonin receptors has been hampered by the lack of specific and selective $\mathrm{MT}_{1}$ melatonin receptor agonists and antagonists. Nevertheless, the use of molecular, pharmacological, and immunohistochemical approaches in conjunction with nonselective $\mathrm{MT}_{1} / \mathrm{MT}_{2}$ melatonin receptor ligands and the use of tissues from animals with genetic deletion of the $\mathrm{MT}_{1}$ and/or $\mathrm{MT}_{2}$ melatonin 
receptors has allowed the identification of several $\mathrm{MT}_{1}$ and $\mathrm{MT}_{2}$ melatonin receptor-mediated functional responses (see Table 6).

Evidence suggests that endogenous melatonin may act to modulate melatonin-mediated functions; however, removal of the pineal gland or genetic deletion of either the $\mathrm{MT}_{1}$, the $\mathrm{MT}_{2}$, or both the $\mathrm{MT}_{1}$ and $\mathrm{MT}_{2}$ melatonin receptors have provided minimal evidence for a functional role of endogenous melatonin. Early studies by Quay (1968, 1970a,b) demonstrated that pinealectomy accelerates the rate of re-entrainment after a shift in the photoperiod, but did not alter re-entrainment either when animals are kept in a light/dark cycle or are free running in constant conditions. These results suggested a role for an endogenous pineal product (e.g., melatonin) on circadian entrainment; however, the mechanism of this phenomenon is still unclear. Mice with genetic deletion of the $\mathrm{MT}_{1}, \mathrm{MT}_{2}$, or $\mathrm{MT}_{1} / \mathrm{MT}_{2}$ melatonin receptors show no circadian phenotype in experiments reported so far (Liu et al., 1997; Jin et al., 2003; Dubocovich et al., 2005; Dubocovich, 2007). Mice lacking the $\mathrm{MT}_{1}$ melatonin receptor display depression-like behavior in the swimming test and deficits in sensory gating as demonstrated in the acoustic startle/prepulse inhibition (Weil et al., 2006). The $\mathrm{MT}_{2}$ receptor knockout mice do not exhibit melatonin-mediated hippocampal long-term potentiation (Wang et al., 2005) or luzindole-mediated decrease in immobility in the swimming test (Sumaya et al., 2005) compared with wild-type (WT) mice. Yasuo et al. (2009) reported that the MT1 melatonin receptor in the mice is directly involved in transmitting photoperiod information and affecting reproductive function. These results then go along with the discovery that the Siberian hamster, a seasonal breeder in which reproductive function responds to changes in photoperiod, does not express the $\mathrm{MT}_{2}$ melatonin receptor (Weaver et al., 1996). Whether these phenotypes are due to lack of activation of melatonin receptors and/or to indirect alterations in brain neuronal pathways remains an open question.

\section{A. Melatonin Receptor Expression}

In mammals, the $\mathrm{MT}_{1}$ and $\mathrm{MT}_{2}$ receptors seem to mediate the physiological effects of endogenous and exogenous melatonin (Reppert et al., 1994, 1995a; Liu et al., 1997; Masana et al., 2002; Dubocovich et al., 2005). As discussed above, these receptors show distinct molecular structures, chromosomal localizations, and pharmacological profiles (Reppert et al., 1994, 1995a; Slaugenhaupt et al., 1995; Dubocovich et al., 1997).

Melatonin receptors have been localized in the human brain and peripheral tissues using receptor autoradiography with $2-\left[{ }^{125} \mathrm{I}\right]$ iodomelatonin, mRNA expression by RT-PCR, and in situ hybridization as well as immunohistochemistry. $\mathrm{MT}_{1}$ and $\mathrm{MT}_{2}$ melatonin receptors mRNA has been amplified from human brain cerebellum, occipital cortex, parietal cortex, temporal cortex, thalamus, frontal cortex, hippocampus, and SCN (Mazzucchelli et al., 1996). Beresford et al. (1998) characterized the pharmacological profile of 2 - $\left[{ }^{125} \mathrm{I}\right]$ iodomelatonin binding in post mortem human cerebellar membranes. The profile of this site is identical to that of the $\mathrm{MT}_{1}$ human recombinant melatonin receptor expressed in either COS-7 or CHO cells (Dubocovich et al., 1997; Beresford et al., 1998). Using in situ hybridization histochemistry, $\mathrm{MT}_{1}$ mRNA was localized to cerebellar granule cells and basket-stellate cells (Mazzucchelli et al., 1996; Weaver and Reppert, 1996; Al-Ghoul et al., 1998). $\mathrm{MT}_{1}$ mRNA also has been localized in the retina and SCN of human postmortem brain, consistent with the important role of these structures in biological rhythmicity (Reppert et al., 1994, 1995a; Mazzucchelli et al., 1996; Weaver and Reppert, 1996). Within the retina, $\mathrm{MT}_{1}$ mRNA and protein have been localized to ganglion, amacrine, and photoreceptor cells using RT-PCR and/or immunohistochemistry (Savaskan et al., 2002a; Scher et al., 2002, 2003). $\mathrm{MT}_{1}$ receptor-like immunoreactivity appears higher in ganglion and amacrine cells from retinas of subjects with Alzheimer's disease, although immunoreactivity was decreased in photoreceptor cells (Savaskan et al., 2002b). $\mathrm{MT}_{1}$ immunoreactivity in the hippocampus was also increased in Alzheimer's disease subjects (Savaskan et al., 2001).

$\mathrm{MT}_{2}$ mRNA has been found in human retina, hippocampus, and whole brain (Reppert et al., 1994, 1995a; Weaver and Reppert, 1996). $\mathrm{MT}_{2}$ melatonin receptor immunoreactivity was localized to ganglion and bipolar cells in the inner nuclear layer of the retina, and to the inner segments of the photoreceptor cells. In addition, cellular processes in inner and outer plexiform layers of the retina were strongly positive for $\mathrm{MT}_{2}$ (Savaskan et al., 2007). Within the hippocampus, $\mathrm{MT}_{2}$ receptors are found in hippocampal pyramidal and granular neurons (Savaskan et al., 2005). In contrast to $\mathrm{MT}_{1}$ receptors, the expression of $\mathrm{MT}_{2}$ receptors was reduced in subjects with Alzheimer's disease in both hippocampal and retinal tissue (Savaskan et al., 2005, 2007). In the cerebellum, the location of $\mathrm{MT}_{2}$ receptor mRNA is distinct from that of $\mathrm{MT}_{1}$ receptors; $\mathrm{MT}_{2}$ expression was restricted to Bergmann glial cells and astrocytes (Al-Ghoul et al., 1998).

$\mathrm{MT}_{1}$ and $\mathrm{MT}_{2}$ receptor mRNAs are also found in nonneural human tissues. Using RT-PCR, mRNA for both types has been amplified from human fetal kidney (Drew et al., 1998), granulosa cells (Niles et al., 1999), PAZ6 adipocytes (Brydon et al., 2001), and coronary arteries (Ekmekcioglu et al., 2001a). $\mathrm{MT}_{1}$ melatonin receptors were localized by immunocytochemistry to both adult and fetal human kidney (Song et al., 1997; Drew et al., 1998). Ekmekcioglu et al. (2001b) observed a 24-h variation in the expression of the $\mathrm{MT}_{1}$ melatonin receptors in coronary arteries derived from patients with coronary heart disease. $\mathrm{MT}_{1}$ receptors were also found in cerebral blood vessels and the central vessels of human 


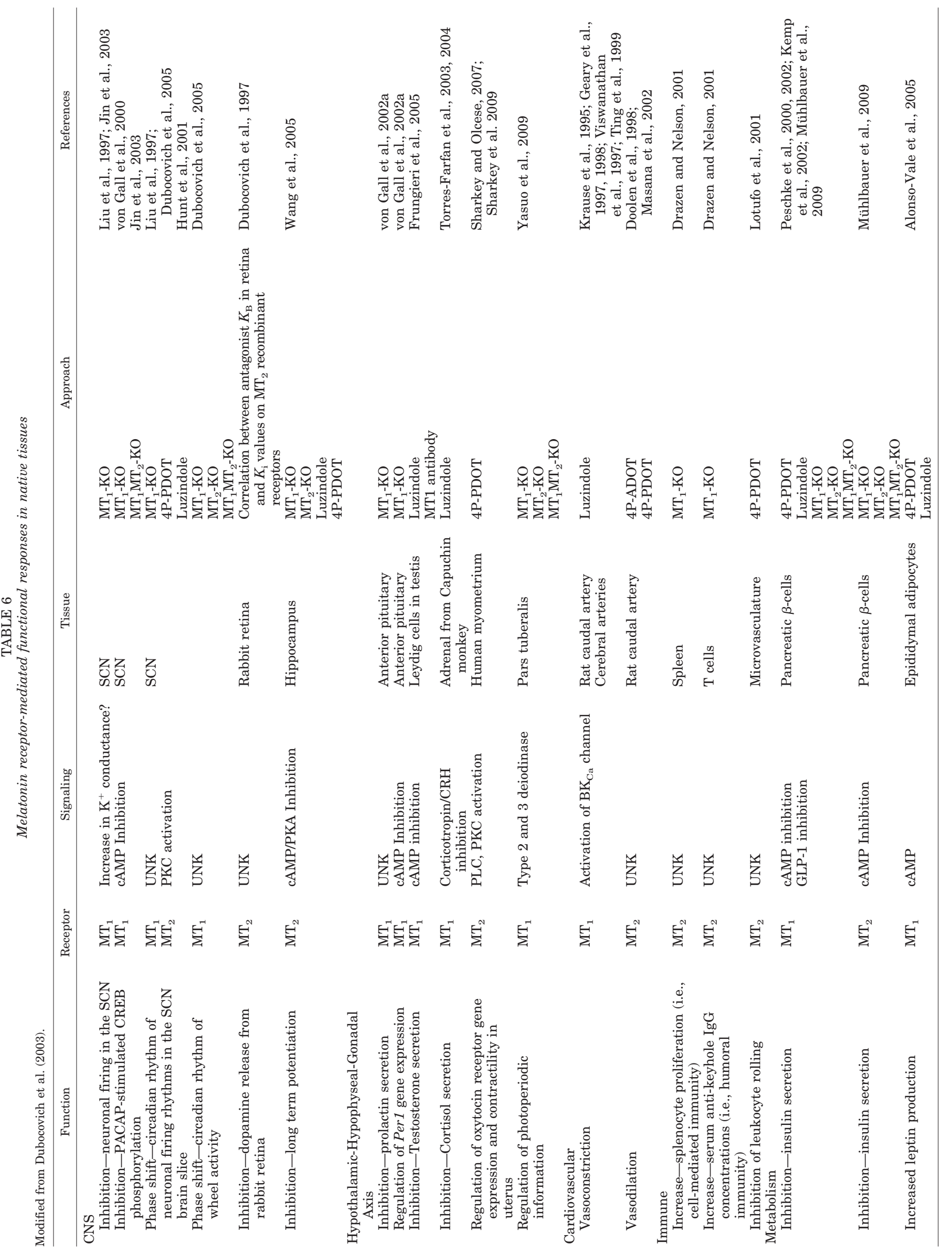




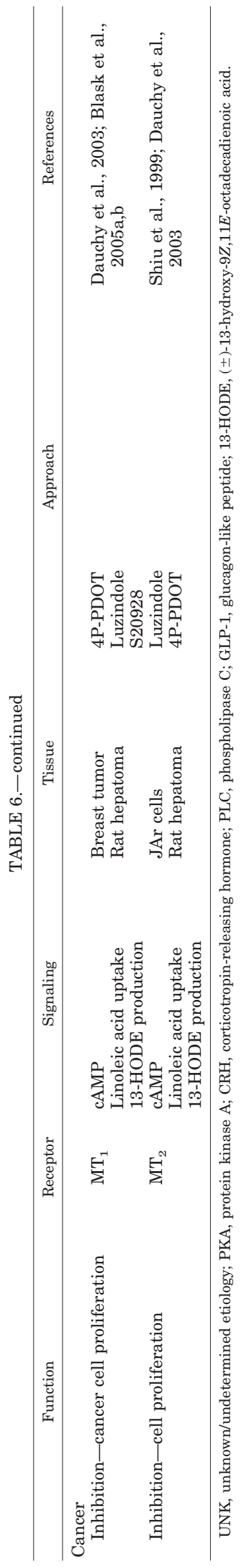

and macaque retinas (Savaskan et al., 2002a; Scher et al., 2002, 2003). $\mathrm{MT}_{1}$ receptor levels were increased in cerebral blood vessels of subjects with Alzheimer's disease (Savaskan et al., 2001).

Mouse and rat brain (e.g., hippocampus), retina, and peripheral tissues such as heart, lung, liver, and kidney (Naji et al., 2004; Sallinen et al., 2005) express mRNA for both $\mathrm{MT}_{1}$ and $\mathrm{MT}_{2}$ melatonin receptors. mRNAs for both receptor types also have been demonstrated in rat vasculature, where $\mathrm{MT}_{1}$ receptors mediate vasoconstriction and $\mathrm{MT}_{2}$ receptors mediate vasodilation (Doolen et al., 1998; Masana et al., 2002).

In the $\mathrm{SCN}$ of the $\mathrm{C} 3 \mathrm{H} / \mathrm{HeN}$ mouse, $\mathrm{MT}_{1}$ and $\mathrm{MT}_{2}$ receptor mRNAs were localized by in situ hybridization (Dubocovich et al., 1998a). $\mathrm{MT}_{1}$ and $\mathrm{MT}_{2}$ melatonin receptor mRNA and protein have been reported in the mammalian SCN (Reppert et al., 1988; Siuciak et al., 1990; Dubocovich et al., 1998a; Hunt et al., 2001; RiveraBermúdez et al., 2004). However, the $\mathrm{MT}_{2}$ melatonin receptor protein in the SCN is expressed at such a low level that it is undetectable by 2 - $\left[{ }^{125} \mathrm{I}\right]$ iodomelatonin binding (Liu et al., 1997; Dubocovich et al., 1998a; Poirel et al., 2002).

Melatonin receptor gene expression can change markedly in neural and peripheral tissues over the lifespan of an organism (Davis, 1997). In addition, 24-h variations in $\mathrm{MT}_{1}$ receptor mRNA expression, as well as repressed $\mathrm{MT}_{1}$ receptor transcription, under short photoperiod conditions have been reported (Masana et al., 2000; Schuster et al., 2001; Poirel et al., 2002). Little is known, however, about the mechanisms that drive these changes in melatonin receptor gene expression. The transcription factors Pitx-1 and Egr-1 have been shown to regulate the MT1 receptor expression in both rats and sheep (Johnston et al., 2003b, 2007).

\section{B. Melatonin Receptor Function}

1. Central Nervous System. In the SCN, functional $\mathrm{MT}_{1}$ and $\mathrm{MT}_{2}$ receptors have been characterized in pharmacological studies using the two melatonin receptor antagonists luzindole and 4P-PDOT as well as in studies of mice with genetic deletion of either the $\mathrm{MT}_{1}$ or/and $\mathrm{MT}_{2}$ receptors (von Gall et al., 2000, 2002a; Jin et al., 2003; Dubocovich et al., 2005). Melatonin applied in vitro to rodent SCN brain slices inhibits neuronal firing in a concentration-dependent manner (Shibata et al., 1989; Liu et al., 1997). Melatonin inhibits neuronal firing in SCN brain slices from wild-type and $\mathrm{MT}_{2} \mathrm{KO}$ mice but not $\mathrm{MT}_{1} \mathrm{KO}$ mice (Liu et al., 1997; Jin et al., 2003). Together, these data suggest that the $\mathrm{MT}_{1}$ receptor mediates the inhibitory effects of melatonin in the SCN (Liu et al., 1997). In the SCN, melatonin, through activation of $\mathrm{MT}_{1}$ melatonin receptors, inhibits pituitary adenylate cyclaseactivating polypeptide-stimulated phosphorylation of the transcription factor CREB, an early event in the signaling cascade leading to phase-shifts of the endog- 
enous clock (von Gall et al., 2000; Jin et al., 2003). These effects of melatonin were not observed in the $\mathrm{MT}_{1} \mathrm{KO}$ mice.

Melatonin released from the pineal gland after a circadian rhythm with high levels at night may exert feedback onto the $\mathrm{SCN}$ and activates $\mathrm{MT}_{1}$ and $\mathrm{MT}_{2}$ receptors to phase shift local and overt circadian rhythms (Gillette and Mitchell, 2002). To determine the melatonin receptor type $\left(\mathrm{MT}_{1}\right.$ and/or $\left.\mathrm{MT}_{2}\right)$ involved in phase shifting circadian rhythms in the SCN, circadian rhythms of neuronal firing in vitro and overt activity rhythms in vivo were measured (Liu et al., 1997; Dubocovich et al., 2005; Dubocovich, 2007). Melatonin (1-10 pM) given at CT10 phase advances, by approximately 3 to $4 \mathrm{~h}$, the circadian rhythms of neuronal firing in rat and mouse SCN. This effect was blocked by $\mathrm{MT}_{2}$-selective concentrations of the competitive melatonin receptor antagonist 4P-PDOT and was absent in SCN from mice with genetic deletion of the $\mathrm{MT}_{2}$ receptor (Hunt et al., 2001; Dubocovich et al., 2005; Dubocovich, 2007). The magnitude of the phase shift induced by melatonin at $10 \mathrm{pM}$ in the SCN brain slice from WT mice and $\mathrm{MT}_{1} \mathrm{KO}$ mice was identical. Together, these results suggest that the $\mathrm{MT}_{2}$ melatonin receptor mediates phase shifting of circadian rhythms of neuronal firing in the SCN in vitro (Liu et al., 1997; Dubocovich et al., 2005). Liu et al. (1997) reported that the phase shift of neuronal firing rhythms induced by the $\mathrm{MT}_{1} / \mathrm{MT}_{2}$ melatonin agonist 2 -iodomelatonin $(10 \mathrm{pM})$ was of smaller magnitude in the SCN brain slice from $\mathrm{MT}_{1} \mathrm{KO}$ mice than in that from the WT mice, suggesting a potential role for $\mathrm{MT}_{1}$ melatonin receptor activation. It is conceivable that in this experimental paradigm, 2-iodomelatonin phase shifted circadian rhythms through the activation of the $\mathrm{MT}_{1}$ (Liu et al., 1997). Recent evidence suggests that melatonin at $1 \mathrm{nM}$ phase advanced circadian rhythms of neuronal firing in the mouse SCN brain slice through activation of $\mathrm{MT}_{1}$ melatonin receptors (R. L. Hudson and M. L. Dubocovich, unpublished observations). Together, these results show that, at least under the experimental conditions used in the mouse, both the $\mathrm{MT}_{1}$ and $\mathrm{MT}_{2}$ receptors mediated phase advances, with the shift induced through activation of the $\mathrm{MT}_{2}$ receptor being significantly larger (Liu et al., 1997; R. L. Hudson and M. L. Dubocovich, unpublished observations). It is noteworthy that in the Siberian hamster, which does not encode a functional melatonin $\mathrm{MT}_{2}$ melatonin receptor, melatonin at $1 \mathrm{nM}$ induced a robust phase shift of the circadian rhythm of neuronal firing rate in the SCN slice (Weaver et al., 1996). Whether this response is mediated by the $\mathrm{MT}_{1}$ melatonin receptor, which is functional in the hamster, or a receptor not yet characterized is an open question.

Studies intended to assess the melatonin receptor type involved in phase-shifting circadian rhythms in an in vivo mouse model led to unexpected results. In this model, melatonin treatment phase-shifted circadian rhythms of wheel-running activity in the WT and $\mathrm{MT}_{2} \mathrm{KO}$ mice kept in constant dark when given $2 \mathrm{~h}$ before onset of activity but not in the $\mathrm{MT}_{1} \mathrm{KO}$ or $\mathrm{MT}_{1} \mathrm{MT}_{2} \mathrm{KO}$ mice, suggesting that in vivo activation of the $\mathrm{MT}_{1}$ receptors phase advances overt circadian rhythms (Dubocovich et al., 2005; Dubocovich, 2007). Melatonin accelerated re-entrainment to an advance in dark onset through activation of the $\mathrm{MT}_{1}$ receptor (Dubocovich et al., 2005). Together, these results suggest the involvement of an $\mathrm{MT}_{1}$ melatonin receptor in the phase-shifting process in vivo. These paradoxical findings (i.e., phase shift by $\mathrm{MT}_{2}$ activation in the SCN in vitro and by $\mathrm{MT}_{1}$ activation in vivo) are difficult to explain at the present time, although it is conceivable that distinct melatonin receptors are necessary to phase-shift circadian rhythms of activity and neuronal firing rhythms. Participation of both the $\mathrm{MT}_{1}$ and $\mathrm{MT}_{2}$ receptors to phase shift circadian rhythms within the SCN cannot be excluded (Liu et al., 1997). The selective $\mathrm{MT}_{2}$ melatonin receptor antagonist 4P-PDOT blocked the melatonin-mediated phase advance of circadian activity rhythms induced by melatonin given in vivo at CT 10 (Dubocovich et al., 1998b), suggesting that melatonin-mediated phase advances were mediated by activation of $\mathrm{MT}_{2}$ melatonin receptors. However, the doses of 4P-PDOT (90 $\mu \mathrm{g} / \mathrm{mouse}$ s.c.) used in the abovementioned report (Dubocovich et al., 1998b) may have raised levels of drug in the circulation to micromolar concentrations that might have blocked both $\mathrm{MT}_{1}$ and $\mathrm{MT}_{2}$ melatonin receptors. Mattson et al. (2003) concluded that a synthetic indanyl piperazine (compound 13) with approximately 117 times higher affinity for the $\mathrm{MT}_{2}$ receptor $\left(K_{\mathrm{i}}=200 \mathrm{nM}\right.$ for $\mathrm{MT}_{1} ; 1.7 \mathrm{nM}$ for $\mathrm{MT}_{2}$ ) phase-shifted circadian activity rhythms in the rat through activation of $\mathrm{MT}_{2}$ receptors using doses of 1 to $56 \mathrm{mg} / \mathrm{kg}$. These doses would probably reach blood concentrations of at least $1 \mu \mathrm{M}$, which would fully activate both the $\mathrm{MT}_{1}$ and $\mathrm{MT}_{2}$ receptors, thereby acting as a nonselective agonist. Further research to determine the specific mechanisms for phase shifting in the SCN is needed to explain these results, as well as to help determine how best to therapeutically target the $\mathrm{MT}_{1}$ and $\mathrm{MT}_{2}$ receptors for treatment of sleep and circadian rhythm disorders.

The first functional $\mathrm{MT}_{2}$ melatonin receptor characterized in a native tissue was the melatonin presynaptic heteroreceptor that modulates the calcium-dependent release of dopamine from rabbit retina (Dubocovich, 1985, 1995; Dubocovich et al., 1997, 1998a). The signaling pathway of the rabbit retina receptor is not known. However, in other tissues, the $\mathrm{MT}_{2}$ receptor seems to be linked to PKC activation; in the rat SCN, activation of an $\mathrm{MT}_{2}$ melatonin receptor, possibly via $\mathrm{G} \beta \gamma$ stimulates PKC (McArthur et al., 1997; Hunt et al., 2001). This 
response is blocked by $4 \mathrm{P}-\mathrm{PDOT}$, a selective $\mathrm{MT}_{2}$ receptor antagonist.

Melatonin inhibits, in a concentration-dependent manner $\left(\mathrm{IC}_{50}=100 \mathrm{nM}\right)$, long-term potentiation and excitability induced by stimulation of the Schaffer collaterals in the cornu ammonis 1 dendritic layer in the mouse hippocampal brain slices (Wang et al., 2005). Luzindole and 4P-PDOT blocked this inhibitory effect of melatonin. Furthermore, the inhibitory effect of melatonin was impaired in the $\mathrm{MT}_{2} \mathrm{KO}$ but not in the $\mathrm{MT}_{1} \mathrm{KO}$ mouse. The protein kinase A inhibitor 5-isoquinolinesulfonamide (H-89) mimicked the inhibitory effect of melatonin on long-term potentiation, whereas forskolin counteracted melatonin-mediated inhibition (Wang et al., 2005). In summary, in the mouse hippocampus, melatonin inhibits long-term potentiation through activation of the $\mathrm{MT}_{2}$ melatonin receptor and inhibition of the adenylyl cyclase-protein kinase A pathway.

More recently it has been reported that exogenous melatonin could increase the survival of neuronal progenitor cells and postmitotic immature neurons in the hippocampus of adult mice (Ramírez-Rodríguez et al., 2009), consistent with melatonin actions on proliferative activity in the rat dentate gyrus and embryonic neural stem cells (Kim et al., 2004; Moriya et al., 2007). These findings are particularly interesting in view of the recent reports that melatonin can reduce learning and memory deficits in mice models of Alzheimer disease (Feng et al., 2004; Olcese et al., 2009).

2. Hypothalamic-Pituitary-Gonadal Axis. Endogenously released melatonin resulting from changes in day length modulates reproduction in seasonal breeders in part through activation of melatonin receptors in the hypothalamic-pituitary-gonadal axis. (Reiter, 1980; Tamarkin et al., 1985; Vanecek, 1998; Malpaux et al., 2001; Roy et al., 2001; Soares et al., 2003; Frungieri et al., 2005). In immortalized GnRH-releasing cells, activation of endogenous $\mathrm{MT}_{1}$ and $\mathrm{MT}_{2}$ receptors decreased the expression of GnRH mRNA in a 24-h cyclical manner, which was blocked by luzindole (Roy et al., 2001). In the neonatal rat pituitary gland, melatonin inhibits GnRH-induced LH release, cAMP and cGMP accumulation, and increases in intracellular $\mathrm{Ca}^{2+}$ through activation of a pertussis toxinsensitive GPCR (Martin et al., 1980; Vanecek and Vollrath, 1990; Vanecek and Klein, 1995). The mechanism(s) by which melatonin modulates pituitary gonadotropin secretion involves activation of $\mathrm{MT}_{1}$ melatonin receptors (Johnston et al., 2003a,b); however, participation of $\mathrm{MT}_{2}$ receptors (Balík et al., 2004) cannot be excluded.

Regulation of ovarian and testicular function by melatonin may involve activation of both $\mathrm{MT}_{1}$ and $\mathrm{MT}_{2}$ receptors along the hypothalamic-pituitary-gonadal axis. Melatonin may also exert direct effects on ovarian function, because it is found in ovarian follicular fluid (Brzezinski et al., 1987; Rönnberg et al., 1990). Specific 2-[ $\left.{ }^{125} \mathrm{I}\right]$ iodomelatonin binding, as well as $\mathrm{MT}_{1}$ and $\mathrm{MT}_{2}$ melatonin receptor mRNAs and $\mathrm{MT}_{1}$ melatonin receptor protein, was identified in various ovarian structures (Niles et al., 1999; Clemens et al., 2001; Woo et al., 2001; Soares et al., 2003). Endogenous estrogens regulate the functional activity of melatonin receptors (Soares et al., 2003), whereas melatonin stimulates progesterone secretion from granulosa cells in several species including humans (Schaeffer and Sirotkin, 1995; Woo et al., 2001). In human granulosa-luteal cells, melatonin increases $\mathrm{LH}$ and decreases $\mathrm{GnRH}$ receptor density (Woo et al., 2001). In hamster testicular Leydig cells, melatonin inhibits basal and chorionic gonadotropin-stimulated cAMP and androgen (testosterone and androstene $3 \alpha$-diol $17 \beta$-diol) production through activation of $\mathrm{MT}_{1}$ receptors (Frungieri et al., 2005).

Prolonged treatment with melatonin causes sensitization of $\mathrm{MT}_{1}$ melatonin receptor signaling upon withdrawal involving potentiation of adenylate cyclase and CREB phosphorylation, leading to increases in gene expression or hormone secretion. Nocturnal melatonin secretion regulates gene expression through heterologous sensitization of adenylate cyclase-linked GPCRs, thereby coupling the central circadian pacemaker with the circadian regulation of peripheral tissues, which results in modulation of circadian and seasonal rhythms. The nocturnal secretion of pineal melatonin suppresses the expression of the clock gene Per1 in the pars tuberalis of the pituitary gland, by inhibiting the cAMP dependent signaling pathway through activation of the $\mathrm{MT}_{1}$ receptor (von Gall et al., 2002a). At dawn, when circulating melatonin levels decrease, the pars tuberalis is released from transcriptional repression, facilitating the induction of Per1 gene expression by heterologous sensitization of adenosine A2b receptors (von Gall et al., 2002a). Furthermore, simultaneously during the biological night, endogenous melatonin, through activation of the $\mathrm{MT}_{1}$ melatonin receptor, inhibits prolactin release in the pars tuberalis (Table 6). This may be a general mechanism by which the circadian production of melatonin provides links to the central circadian pacemaker and peripheral tissues, imparting the signal of darkness.

A relationship between the circadian rhythm of melatonin and adrenal hormone secretion has been described in mammals. In humans, plasma cortisol peaks in the early morning but remains low during the night when circulating melatonin levels are high (Weitzman et al., 1971). Adult and fetal adrenal gland of the capuchin monkey expresses $2-\left[{ }^{125} \mathrm{I}\right]$ iodomelatonin binding sites and $\mathrm{MT}_{1}$ but not $\mathrm{MT}_{2}$ melatonin receptor mRNA (Torres-Farfan et al., 2003, 2004). Melatonin inhibited corticotropin-releasing hormone- and adrenocorticotropin-induced cortisol production and decreased dibutryl cAMP-induced cortisol secretion from adrenal cultured cells. This $\mathrm{MT}_{1}$-mediated effect was blocked by luzindole.

In several mammalian species, changes in photoperiod regulate reproduction via the duration of the melatonin signal known to encode the length of the night (Bartness et al., 1993). Reproduction in ham- 
sters is regulated by melatonin-mediated photoperiodic signals; however, this species does not express functional $\mathrm{MT}_{2}$ melatonin receptors (Weaver et al., 1996). Although reproductive responses are assumed to be mediated by activation of $\mathrm{MT}_{1}$ melatonin receptors, direct evidence for this assumption was missing. Yasuo et al. (2009) recently reported differential regulation of photoperiod-induced changes in Diodinase 2 and Diodinase 3 expression (Ono et al., 2008) in C3H mice with genetic disruption of the $\mathrm{MT}_{1}, \mathrm{MT}_{2}$, or $\mathrm{MT}_{1} \mathrm{MT}_{2}$ melatonin receptors. These studies provided evidence for distinct functions for the $\mathrm{MT}_{1}$ and $\mathrm{MT}_{2}$ melatonin receptors in the regulation of photoperiodic responses in pars tuberalis and confirmed that melatonin through activation of the $\mathrm{MT}_{1}$ melatonin receptor transmit photoperiod information to the hypothalamus-hypophysial axis to regulate reproductive function (Yasuo et al., 2009).

3. Cardiovascular System. A number of studies point to a role for melatonin in cardiovascular regulation (Krause et al., 1999). $\mathrm{MT}_{1}$ and $\mathrm{MT}_{2}$ protein and mRNA are expressed in peripheral and cerebral arteries of various species, including humans (Savaskan et al., 2001; Masana et al., 2002). Activation of $\mathrm{MT}_{1}$ and $\mathrm{MT}_{2}$ receptors mediates vasoconstriction and vasodilation, respectively. In the rat caudal artery, which is important for thermoregulation, melatonin causes vasoconstriction, directly contracting pressurized arterial segments (Evans et al., 1992) and potentiating contraction induced by adrenergic nerve stimulation or norepinephrine (Krause et al., 1995; Geary et al., 1998). Various melatonin receptor analogs act as full or partial agonists in the rat caudal artery model, the enantiomers of the melatonin agonist $N$-acetyl-4-aminomethyl6-methoxy-9-methyl-1,2,3,4-tetrahydrocarbazole showing a difference (400-fold) in vasoconstrictor potency matching the known difference in melatonin receptor affinity of the two enantiomers (Krause et al., 1995; Ting et al., 1997) Vasoconstriction seems to be mediated by $\mathrm{MT}_{1}$ receptors because it is not blocked by the $\mathrm{MT}_{2}$ selective antagonist 4P-PDOT (Doolen et al., 1998; Masana et al., 2002). In fact, vasoconstrictor effects of melatonin in caudal arteries are further enhanced in the presence of 4P-PDOT, consistent with the blockade of $\mathrm{MT}_{2}$ receptors that mediate vasodilation (Doolen et al., 1998; Masana et al., 2002), although $\mathrm{MT}_{2}$ mRNA has not been detected in all studies (Table 1). Vasodilation and an increase in blood flow induced by melatonin in distal skin regions may be responsible for the hypothermic effect of this hormone in humans (Kräuchi et al., 2000).

Melatonin-mediated vasoconstriction in cerebral arteries is blocked by the competitive melatonin receptor antagonists luzindole and S 20928, by pertussis toxin, and by blockers of $\mathrm{BK}_{\mathrm{Ca}}$ channels (Viswanathan et al., 1990; Geary et al., 1997; Mahle et al., 1997) (Table 1). $\mathrm{MT}_{1}$ melatonin receptors in cerebral arteries and hippocampal microvasculature seem to regulate blood flow (Savaskan et al., 2001). It is suggested that melatonin- mediated vasoconstriction enhances cerebrovascular autoregulation, thereby keeping cerebral blood flow constant in the face of diurnal fluctuations in blood pressure (Régrigny et al., 1998).

4. Immune System. Melatonin receptors expressed in lymphoid cells seem to be involved in regulating immune responses (for review, see Guerrero and Reiter, 2002; Skwarlo-Sonta et al., 2003). Luzindole blocks melatonin-mediated enhancement of splenic lymphocyte proliferation in mice independent of time of day (Drazen et al., 2001). This effect of melatonin seems to be mediated through activation of the $\mathrm{MT}_{2}$ receptor, because the effect of melatonin on splenocyte proliferation (e.g., cellmediated immunity) was also observed in mice with genetic deletion of the $\mathrm{MT}_{1}$ melatonin receptor (Drazen and Nelson, 2001). In rat microvasculature, $\mathrm{MT}_{2}$ activation also reduces acute inflammation by inhibiting leukocyte rolling (Lotufo et al., 2001). In human lymphocytes $\mathrm{MT}_{1}$ receptor activation counteracts the inhibitory effect of prostaglandin $\mathrm{E}_{2}$ on interleukin 2 production (Carrillo-Vico et al., 2003; Carrillo-Vico et al., 2005). Activation of $\mathrm{MT}_{2}$ receptors modulates immune responses, providing a mechanism by which endogenous melatonin may participate in adaptation to seasonal changes (Table 1).

5. Metabolism. A relationship between the circadian release of melatonin and energy balance has been described (Barrenetxe et al., 2004). Melatonin modulates glucose homeostasis mainly via changes in insulin secretion and leptin production. Pancreatic islets and INS- 1 insulinoma cells, a model of pancreatic $\beta$ cells, express high-affinity 2 -[ $\left.{ }^{125} \mathrm{I}\right]$ iodomelatonin binding sites and $\mathrm{MT}_{1}$ and $\mathrm{MT}_{2}$ melatonin receptor mRNA (Peschke et al., 2000, 2002; Kemp et al., 2002). The expression of $\mathrm{MT}_{1}$ and $\mathrm{MT}_{2}$ receptors has also been reported for human pancreatic tissue (Peschke et al., 2007). Activation of $\mathrm{MT}_{1}$ melatonin receptors inhibits cAMP-stimulated insulin secretion through pertussis toxin sensitive$\mathrm{G}_{\mathrm{i}} / \mathrm{G}_{\mathrm{o}}$ protein coupling. (Peschke et al., 2000, 2002; Kemp et al., 2002). In INS-1 insulinoma cells, melatonin attenuates glucagon-like peptide (GLP-1), forskolinstimulated insulin secretion, insulin promoter activity, and CREB-mediated gene expression (Kemp et al., 2002) (Table 1).

Prolonged melatonin pretreatment of pancreatic $\beta$-cells, via activation of $\mathrm{MT}_{1}$ melatonin receptors and cross-talk with GLP-1 receptors, sensitizes the cAMP signaling system, increasing cAMP production and insulin secretion. In rat pancreatic islets and INS-1 cells, long-term melatonin treatment increased basal levels of insulin secretion and potentiated GLP-1- and forskolin-induced insulin and cAMP production (Kemp et al., 2002). Endogenous melatonin released during the night seems to sensitize the cAMP system in $\beta$-cells, leading to potentiation of insulin release upon GLP-1 receptor stimulation by endogenous incretin (Kemp et al., 2002). The sensitization of the cAMP system by endogenous melatonin may influence the circa- 
dian profile for insulin release and could provide a mechanism by which high morning levels of insulin facilitate glucose disposal after nutritional stimuli (Kemp et al., 2002). Melatonin has also been shown to act via the $\mathrm{MT}_{2}$ receptor in pancreatic $\beta$-cells to inhibit cyclic GMP signaling (Stumpf et al., 2008, 2009).

Melatonin receptor activation modulates rat adipocyte function via activation of $\mathrm{MT}_{1}$ and $\mathrm{MT}_{2}$ melatonin receptors expressed in inguinal and epididymal adipocytes (Zalatan et al., 2001). In epididymal adipocytes, melatonin in the presence of insulin increases leptin secretion and counteracts forskolin-induced inhibition of leptin secretion and mRNA expression through activation of a melatonin receptor. This suggests cross-talk between these hormones to modulate leptin production from adipocytes via $\mathrm{MT}_{1}$ receptor activation (Alonso-Vale et al., 2005). In human adipocytes, activation of $\mathrm{MT}_{2}$ melatonin receptors modulates glucose uptake (Brydon et al., 2001). In summary, melatonin seems to modulate glucose homeostasis and energy balance via its direct effect on pancreatic $\beta$ cells and adipocytes through activation of $\mathrm{MT}_{1}$ and $\mathrm{MT}_{2}$ melatonin receptors. Furthermore, melatonin inhibits insulin secretion in isolated islets and beta cells from rodents and human through activation of $\mathrm{MT}_{1}$ and/or $\mathrm{MT}_{2}$ melatonin receptors (Mühlbauer and Peschke, 2007; Lyssenko et al., 2009; Mühlbauer et al., 2009). Mühlbauer et al. (2009) reported that insulin secretion from isolated islets of melatonin receptor $\mathrm{MT}_{1}$, $\mathrm{MT}_{2}$, and $\mathrm{MT}_{1} / \mathrm{MT}_{2}$ knockout mice was modulated by melatonin. Together these data suggest that both the $\mathrm{MT}_{1}$ and $\mathrm{MT}_{2}$ receptor may be involved in the pathogenesis of some form of diabetes.

6. Cancer. Melatonin decreased cancer cell growth by affecting cell proliferation and cytokine secretion, reducing tumor number and size, increasing tumor latency, and lowering tumor incidence (for review, see Pawlikowski et al., 2002; Sánchez-Barceló et al., 2003). Melatonin inhibits cell proliferation through receptor-mediated effects on the cell cycle (Shiu et al., 1999), interaction with sex steroid-responsive pathways (Sánchez-Barceló et al., 2003), and/or perhaps in part via its free radical scavenging potential (Reiter et al., 2001).

$\mathrm{MT}_{1}$ and/or $\mathrm{MT}_{2}$ melatonin receptors are expressed on LNCaP prostate tumor cells, MCF-7 breast cancer cells (Xi et al., 2001; Ram et al., 2002), colon 38 cancer cells (Karasek et al., 2002), human choriocarcinoma JEG-3 cells (Shiu et al., 2000), human gall bladder adenocarcinoma epithelial cells (Aust et al., 2004), and malignant breast epithelium cells (Dillon et al., 2002). The oncostatic action of melatonin seems to be mediated primarily through activation of $\mathrm{MT}_{1}$ melatonin receptors, but an action on the $\mathrm{MT}_{2}$ receptors cannot be excluded (Shiu et al., 1999, 2000). Melatonin inhibited endometrial cancer cell growth in in vitro studies with estrogen receptorpositive Ishikawa cells (Kanishi et al., 2000). It induced neurite growth in N1E-115 neuroblastoma cells (Bordt et al., 2001) and inhibited proliferation of MCF-7 cells (Ram et al., 2002). Several cellular mechanisms have been suggested to mediate melatonin's oncostatic effects. The best-characterized cellular pathway is the suppression of linoleic acid uptake and its conversion to 13-hydroxyoctadecadienoic acid, which normally activates EGFR/MAPK mitogenic signaling (Blask et al., 2002, 2005a). Endogenous nocturnal levels of melatonin attenuate linoleic acid uptake, and its conversion to 13-hydroxyoctadecadienoic acid decreases cell proliferation and cAMP through a melatonin receptor-mediated effect (Blask et al., 2005a).

$\mathrm{MT}_{1}$ melatonin receptor overexpression facilitates melatonin-mediated oncostatic action. Melatonin administration decreases the weight and volume of S-91 melanoma tumors in mice in vivo, and melatonin inhibits S-91 cell proliferation in vitro (Kadekaro et al., 2004), which was dramatically potentiated by expression of $\mathrm{MT}_{1}$ melatonin receptors (Kadekaro et al., 2004). Overexpression of $\mathrm{MT}_{1}$ receptor in MCF-7 breast cancer cells facilitates melatonin-mediated tumor growth inhibition in vivo and in vitro (Collins et al., 2003) through a melatonin receptor mediated mechanism (Yuan et al., 2002). Overexpression of $\mathrm{MT}_{1}$ melatonin receptors in MCF-7 cells seems to suppress tumor formation in vivo, probably by increasing expression of constitutively active $\mathrm{MT}_{1}$ receptors (Collins et al., 2003). Together, these data suggest that oncostatic effects of melatonin occur primarily through activation of $\mathrm{MT}_{1}$ melatonin receptors and/or enhancement of constitutive receptor activity (Table 1).

\section{Melatonin receptors as therapeutic targets}

Melatonin receptor agonists currently on the market or in advanced stages of development are all $\mathrm{MT}_{1} /$ $\mathrm{MT}_{2}$-nonselective melatonin receptor agonists. These agonists are indicated or being developed for a number of conditions ranging from insomnia and circadian entrainment to depression and seasonal affective disorder. Melatonin and the synthetic melatonin agonists are generally devoid of the common side effects frequently observed with sleep medication (e.g., impairment of learning, memory, or motor function).

\section{A. Agomelatine}

The nonselective melatonin agonist agomelatine (S 20098) has been studied extensively using in vitro and in vivo models (Racagni et al., 2007) (Fig. 7A). This high-affinity $\mathrm{MT}_{1} / \mathrm{MT}_{2}$ melatonin receptor agonist is also a $5-\mathrm{HT}_{2 \mathrm{C}}$ serotonin receptor antagonist (Conway et al., 2000; Audinot et al., 2003; Millan et al., 2003). The European Medicines Agency recently granted approval to agomelatine for major depression. In addition, agomelatine promotes sleep in human volunteers and phase-shifts circadian rhythms (Cajochen et al., 1997). 
Agomelatine, a novel and efficacious antidepressant, shows a unique pharmacological profile with high efficacy on sleep, circadian rhythm dysfunction, and depression (Dubocovich, 2006; Ghosh and Hellewell, 2007; Montgomery and Kasper, 2007; Olié and Kasper, 2007). Agomelatine was found to be significantly more effective than placebo in the treatment of major depression, with significantly reduced depression scores in the 17-item Hamilton Rating Scale for Depression and several other criteria (Lôo et al., 2002, 2003) after 2 weeks of treatment. Agomelatine showed higher efficacy than paroxetine, a specific serotoninreuptake inhibitor, and both were effective in the treatment of anxiety symptoms in depression (Lôo et al., 2003). Agomelatine's profile of adverse effects, including discontinuation symptoms, is comparable with that of placebo and less than that of paroxetine (Judge et al., 2002; Lôo et al., 2003; Montgomery et al., 2004). Agomelatine seems to have an advantage over other current antidepressant treatments in that it promotes sleep (Cajochen et al., 1997; Guilleminault, 2005), entrains circadian rhythms (Kräuchi et al., 1997; QueraSalva et al., 2005), and shows anxiolytic effects and a faster onset of therapeutic effectiveness (Lôo et al., 2002; Montgomery et al., 2004; Kennedy, 2005). It also lacks the prominent side effects shown by most classes of antidepressants, such as sexual dysfunction, gastrointestinal reactions, and discontinuation symptoms (Lôo et al., 2002; Millan et al., 2003; Montgomery et al., 2004).

\section{B. Ramelteon}

Ramelteon is a novel, high-affinity, nonselective $\mathrm{MT}_{1} /$ $\mathrm{MT}_{2}$ receptor agonist with little affinity for other GPCRs that was developed for the treatment of insomnia and circadian sleep disorders (for reviews, see Cajochen, 2005; Miyamoto, 2009) (Fig. 7A). In freely moving cats (Miyamoto et al., 2004) and monkeys (Yukuhiro et al., 2004), ramelteon promotes sleep, showing higher efficacy than melatonin. Fisher et al. (2008) demonstrated that both melatonin and ramelteon administration (10 $\mathrm{mg} / \mathrm{kg}$ i.p.) had an acute, short-lasting, sleep-promoting effect in the rat, as determined using implanted radiotelemetry transmitters to record electroencephalogram and electromyogram parameters. Ramelteon received approval from the FDA in 2005 for the treatment of insomnia characterized by difficulty in sleep onset, and it is the only hypnotic drug indicated for long-term treatment. Ramelteon does not affect learning, memory, or motor function and is devoid of rewarding properties (Meier et al., 1988). In humans with primary chronic insomnia, this novel melatonin receptor agonist decreases the latency to sleep and increases total sleep time and sleep efficiency (Erman et al., 2006).

\section{PD 6735 (LY 156735)}

PD 6735 is a close indole analog of melatonin that shows high affinity for both $\mathrm{MT}_{1}$ and $\mathrm{MT}_{2}$ receptors. In subjects with moderate to severe insomnia, PD 6735 given for 2 consecutive days reduced sleep latency as determined by polysomnography and reduced subjective sleep latency (Fig. 7C). PD 6735 did not negatively affect other sleep parameters or produce morning-after psychomotor impairment (Mulchahey et al., 2004; Zemlan et al., 2005). PD 6735 did not cause hypothermia, hypertension, or bradycardia.

\section{Circadin}

Circadin has recently been approved for marketing in Europe as a prolonged-release melatonin formulation that mimics the physiological secretion profile of melatonin. The clinical development of Circadin is based on the controlled clinical studies by Garfinkel et al. (1997), Leger et al. (2004), and Haimov et al. (1995), which showed that it improves sleep quality in elderly insomnia patients. Circadin was found to be effective in improving quality of sleep and sleep latency and in improving daytime function. It was not associated with memory impairment or decreased vigilance, and it had no significant withdrawal symptoms. In exploratory studies, Circadin also improved sleep quality in children with sleepwake cycle disorders as shown in studies by De Leersnyder et al. (2003).

\section{Conclusion}

This review describes the molecular, pharmacological, and functional properties of the two mammalian G-protein-coupled melatonin receptors (i.e., $\mathrm{MT}_{1}$ and $\mathrm{MT}_{2}$ ). The availability of melatonin receptor ligands with well defined pharmacological properties and selectivity, advances in the molecular biology of the melatonin receptors, the discovery of novel cellular and signaling mechanisms transducing effector responses, and the creation of transgenic mice with targeted deletion of the $\mathrm{MT}_{1}$ and/or $\mathrm{MT}_{2}$ melatonin receptors have increased our understanding of the role of melatonin and its receptors in the modulation of visual, circadian, seasonal, cardiovascular, endocrine, and immune function as well as cancer cell growth.

The cellular and molecular mechanisms by which circadian and seasonal changes in melatonin levels regulate receptor functioning are not fully understood. Studies on melatonin regulation of cellular trafficking and receptor oligomerization will provide new insights into the hormone signaling pathways. The role of proteinprotein interactions leading to receptor dimerization and heterodimerization, the presence of intracellular partners in signal transmission, cross-talk via signal transduction cascades, and the role of constitutively active receptors in effector responses all need to be further investigated to understand better the physiological role 
of the melatonin receptors and the development of drugs with therapeutic potential. The identification of novel targets for the treatment of disorders involving alterations in the melatonin system should provide new opportunities for therapeutic targets. Discovery of specific and selective agonists and antagonists for the $\mathrm{MT}_{1}$ and $\mathrm{MT}_{2}$ melatonin receptors would provide additional tools for the study of melatonin function and the design of novel therapeutics. The discovery of constitutively active $\mathrm{MT}_{1}$ melatonin receptors opens up the additional possibility of developing inverse agonists as therapeutic tools. A unique feature of the melatonin message that must always be taken into account is that it is time-dependent. Effects of melatonin and melatonin-related drugs are affected by time of day and duration of exposure, probably because of changes in the diurnal sensitivity and/or efficacy of $\mathrm{MT}_{1}$ and $\mathrm{MT}_{2}$ melatonin receptors. Treatments mimicking the length of the physiological nocturnal melatonin profile may differentially regulate $\mathrm{MT}_{1}$ and $\mathrm{MT}_{2}$ receptor function. Furthermore, through activation of distinct receptors types expressed within the same tissue or perhaps in the same cell, melatonin may exert distinct and/or opposite physiological responses. Our current knowledge on the mechanism(s) by which melatonin affects physiology through activation of specific membrane receptors is exciting but still in its infancy. Better understanding of these processes will facilitate discovery and development of melatonergic agents for the treatment of sleep, circadian, metabolic, and endocrine disorders, as well as tumor cell growth.

Acknowledgments. This work was supported by the National Institutes of Health National Institute of Mental Health [Grants MH42922, MH52585]; the Wellcome Trust [Grant 065816]; the Leidenberger-Muller and the Buch Foundations (Hamburg, Germany); the Florida State University Council for Research and Creativity; and the Johnnie B. Byrd, Sr. Alzheimer Research Center. We thank Dr. Richard R. Neubig for his encouragement and invaluable comments during the preparation of this review. Special thanks go to Jeremy M. Davies and Elizabeth A. Marshall for outstanding editorial assistance. We thank Dr. R. V. Rajnarayanan for help with the nomenclature for the amino acid mutations. We thank all former and current members of our laboratories and all collaborators who contributed to the published work discussed in this review.

Conflict of interest: M.L.D. has received research support through an investigator-initiated research grant from Takeda Pharmaceuticals North America, has served as consultant and/or speaker for Glaxo Wellcome, Institute de Researches Internationale Servier, Eli Lilly and Company, Pfizer Inc., Shire Pharmaceuticals Group, Johnson \& Johnson Pharmaceutical Research \& Development, Vanda Pharmaceuticals; Takeda Pharmaceuticals North America, Takeda Pharmaceutical Company Limited, Novartis Pharmaceutical Corporation, Forest Laboratories Inc, and Adolor Corporation, and has solicited unrestricted educational grants awarded to Northwestern University from Takeda Pharmaceuticals North America. P.D. is an employee of the Institute de Researches Internationale Servier, which holds the patent for agomelatine and a number of compounds listed in this review. D.P.C. has served as a consultant for Elisium SA., Buenos Aires, Argentina. J.O. has served as speaker for Takeda Pharmaceuticals North America.

\section{REFERENCES}

Al-Ghoul WM, Herman MD, and Dubocovich ML (1998) Melatonin receptor subtype expression in human cerebellum. Neuroreport 9:4063-4068.

Alonso-Vale MI, Andreotti S, Peres SB, Anhê GF, das Neves Borges-Silva C, Neto JC, and Lima FB (2005) Melatonin enhances leptin expression by rat adipocytes in the presence of insulin. Am J Physiol Endocrinol Metab 288:E805-E812.

Arendt J (2000) Melatonin, circadian rhythms, and sleep. N Engl J Med 343:11141116.

Arendt J and Skene DJ (2005) Melatonin as a chronobiotic. Sleep Med Rev 9:25-39. Arnis S, Fahmy K, Hofmann KP, and Sakmar TP (1994) A conserved carboxylic acid group mediates light-dependent proton uptake and signaling by rhodopsin. J Biol Chem 269:23879-23881.

Audinot V, Bonnaud A, Grandcolas L, Rodriguez M, Nagel N, Galizzi JP, Balik A, Messager S, Hazlerigg DG, Barrett P, et al. (2008) Molecular cloning and pharmacological characterization of rat melatonin MT1 and MT2 receptors. Biochem Pharmacol 75:2007-2019.

Audinot V, Mailliet F, Lahaye-Brasseur C, Bonnaud A, Le Gall A, Amossé C, Dromaint S, Rodriguez M, Nagel N, Galizzi JP, et al. (2003) New selective ligands of human cloned melatonin MT1 and MT2 receptors. Naunyn Schmiedebergs Arch Pharmacol 367:553-561.

Aust S, Thalhammer T, Humpeler S, Jäger W, Klimpfinger M, Tucek G, Obrist P, Marktl W, Penner E, and Ekmekcioglu C (2004) The melatonin receptor subtype MT1 is expressed in human gallbladder epithelia. J Pineal Res 36:43-48.

Ayoub MA, Couturier C, Lucas-Meunier E, Angers S, Fossier P, Bouvier M, and Jockers R (2002) Monitoring of ligand-independent dimerization and ligandinduced conformational changes of melatonin receptors in living cells by bioluminescence resonance energy transfer. J Biol Chem 277:21522-21528.

Ayoub MA, Levoye A, Delagrange P, and Jockers R (2004) Preferential formation of MT1/MT2 melatonin receptor heterodimers with distinct ligand interaction properties compared with MT2 homodimers. Mol Pharmacol 66:312-321.

Balík A, Kretschmannová K, Mazna P, Svobodová I, and Zemková H (2004) Melatonin action in neonatal gonadotrophs. Physiol Res 53:S153-166.

Baldwin JM (1993) The probable arrangement of the helices in G protein-coupled receptors. EMBO J 12:1693-1703.

Ballesteros JA, Deupi X, Olivella M, Haaksma EE, and Pardo L (2000) Serine and threonine residues bend alpha-helices in the chi(1) $=\mathrm{g}(-)$ conformation. Biophys $J$ 79:2754-2760

Ballesteros JA, Shi L, and Javitch JA (2001) Structural mimicry in G protein-coupled receptors: implications of the high-resolution structure of rhodopsin for structurefunction analysis of rhodopsin-like receptors. Mol Pharmacol 60:1-19.

Ballesteros JA and Weinstein H (1995) Integrated Methods for the Construction of Three-Dimensional Models and Computational Probing of Structure-Function Relations in G Protein-Coupled Receptors, in Methods in Neuroscience: Receptor Molecular Biology (Sealfon SC ed) pp 366-428, Academic Press, San Diego.

Barrenetxe J, Delagrange P, and Martínez JA (2004) Physiological and metabolic functions of melatonin. $J$ Physiol Biochem 60:61-72.

Barrett P, Conway S, Jockers R, Strosberg AD, Guardiola-Lemaitre B, Delagrange P, and Morgan PJ (1997) Cloning and functional analysis of a polymorphic variant of the ovine Mel 1a melatonin receptor. Biochim Biophys Acta 1356:299-307.

Barrett P, Conway S, and Morgan PJ (2003) Digging deep—structure-function relationships in the melatonin receptor family. J Pineal Res 35:221-230.

Barrett P, Ivanova E, Graham ES, Ross AW, Wilson D, Plé H, Mercer JG, Ebling FJ, Schuhler S, Dupré SM, et al. (2006) Photoperiodic regulation of cellular retino binding protein, CRBP1 and nestin in tanycytes of the third ventricle ependymal layer of the Siberian hamster. J Endocrinol 191:687-698.

Bartness TJ, Powers JB, Hastings MH, Bittman EL, and Goldman BD (1993) The timed infusion paradigm for melatonin delivery: what has it taught us about the melatonin signal, its reception, and the photoperiodic control of seasonal responses? J Pineal Res 15:161-190.

Beaubien G, Rosinski-Chupin I, Mattei MG, Mbikay M, Chrétien M, and Seidah NG (1991) Gene structure and chromosomal localization of plasma kallikrein. Biochemistry 30:1628-1635.

Beresford IJ, Browning C, Starkey SJ, Brown J, Foord SM, Coughlan J, North PC, Dubocovich ML, and Hagan RM (1998) GR196429: a nonindolic agonist at highaffinity melatonin receptors. J Pharmacol Exp Ther 285:1239-1245.

Berson DM, Dunn FA, and Takao M (2002) Phototransduction by retinal ganglion cells that set the circadian clock. Science 295:1070-1073.

Blask DE, Brainard GC, Dauchy RT, Hanifin JP, Davidson LK, Krause JA, Sauer LA, Rivera-Bermudez MA, Dubocovich ML, Jasser SA, et al. (2005a) Melatonindepleted blood from premenopausal women exposed to light at night stimulates growth of human breast cancer xenografts in nude rats. Cancer Res 65:1117411184 .

Blask DE, Dauchy RT, and Sauer LA (2005b) Putting cancer to sleep at night: the neuroendocrine/circadian melatonin signal. Endocrine 27:179-188.

Blask DE, Sauer LA, and Dauchy RT (2002) Melatonin as a chronobiotic/anticancer agent: cellular, biochemical, and molecular mechanisms of action and their implications for circadian-based cancer therapy. Curr Top Med Chem 2:113-132.

Bordt SL, McKeon RM, Li PK, Witt-Enderby PA, and Melan MA (2001) N1E-115 mouse neuroblastoma cells express MT1 melatonin receptors and produce neurites in response to melatonin. Biochim Biophys Acta 1499:257-264

Borjigin J, Li X, and Snyder SH (1999) The pineal gland and melatonin: molecular and pharmacologic regulation. Annu Rev Pharmacol Toxicol 39:53-65.

Borjigin J, Wang MM, and Snyder SH (1995) Diurnal variation in mRNA encoding serotonin N-acetyltransferase in pineal gland. Nature 378:783-785.

Bouatia-Naji N, Bonnefond A, Cavalcanti-Proença C, Sparsø T, Holmkvist J, Marchand M, Delplanque J, Lobbens S, Rocheleau G, Durand E, et al. (2009) A variant near MTNR1B is associated with increased fasting plasma glucose levels and type 2 diabetes risk. Nat Genet 41:89-94.

Browning C, Beresford I, Fraser N, and Giles H (2000) Pharmacological character- 
ization of human recombinant melatonin $\mathrm{mt}(1)$ and $\mathrm{MT}(2)$ receptors. $\mathrm{Br} J$ Pharmacol 129:877-886.

Brydon L, Petit L, de Coppet P, Barrett P, Morgan PJ, Strosberg AD, and Jockers R (1999a) Polymorphism and signalling of melatonin receptors. Reprod Nutr Dev 39:315-324.

Brydon L, Petit L, Delagrange P, Strosberg AD, and Jockers R (2001) Functional expression of MT2 (Mel1b) melatonin receptors in human PAZ6 adipocytes. Endocrinology 142:4264-4271.

Brydon L, Roka F, Petit L, de Coppet P, Tissot M, Barrett P, Morgan PJ, Nanoff C Strosberg AD, and Jockers R (1999b) Dual signaling of human Mel1a melatonin receptors via G(i2), G(i3), and G(q/11) proteins. Mol Endocrinol 13:2025-2038.

Brzezinski A, Seibel MM, Lynch HJ, Deng MH, and Wurtman RJ (1987) Melatonin in human preovulatory follicular fluid. J Clin Endocrinol Metab 64:865-867.

Cagnacci A, Arangino S, Angiolucci M, Melis GB, Tarquini R, Renzi A, and Volpe A (2000) Different circulatory response to melatonin in postmenopausal women without and with hormone replacement therapy. J Pineal Res 29:152-158.

Cajochen C (2005) TAK-375 Takeda. Curr Opin Investig Drugs 6:114-121.

Cajochen C, Kräuchi K, Möri D, Graw P, and Wirz-Justice A (1997) Melatonin and S-20098 increase REM sleep and wake-up propensity without modifying NREM sleep homeostasis. Am J Physiol 272:R1189-R1196.

Capsoni S, Viswanathan M, De Oliveira AM, and Saavedra JM (1994) Characterization of melatonin receptors and signal transduction system in rat arteries forming the circle of Willis. Endocrinology 135:373-378.

Cardinali DP (1981) Melatonin. A mammalian pineal hormone. Endocr Rev 2:327346.

Cardinali DP, Golombek DA, Rosenstein RE, Cutrera RA, and Esquifino AI (1997) Melatonin site and mechanism of action: single or multiple? J Pineal Res 23:32-39

Cardinali DP, Lynch HJ, and Wurtman RJ (1972) Binding of melatonin to human and rat plasma proteins. Endocrinology 91:1213-1218.

Cardinali DP and Pévet P (1998) Basic aspects of melatonin action. Sleep Med Rev 2:175-190.

Cardinali DP, Vacas MI, and Boyer EE (1979) Specific binding of melatonin in bovine brain. Endocrinology 105:437-441.

Carrillo-Vico A, García-Mauriño S, Calvo JR, and Guerrero JM (2003) Melatonin counteracts the inhibitory effect of PGE2 on IL-2 production in human lymphocytes via its mt1 membrane receptor. FASEB J 17:755-757.

Carrillo-Vico A, Lardone PJ, Fernández-Santos JM, Martín-Lacave I, Calvo JR, Karasek M, and Guerrero JM (2005) Human lymphocyte-synthesized melatonin is involved in the regulation of the interleukin-2/interleukin-2 receptor system. $J$ Clin Endocrinol Metab 90:992-1000.

Castrillón PO, Esquifino AI, Varas A, Zapata A, Cutrera RA, and Cardinali DP (2000) Effect of melatonin treatment on 24-h variations in responses to mitogens and lymphocyte subset populations in rat submaxillary lymph nodes. J Neuroendocrinol 12:758-765.

Clemens JA and Flaugh ME (1986) Development of drugs to modify the actions of melatonin. J Neural Transm Suppl 21:451-459.

Clemens JW, Jarzynka MJ, and Witt-Enderby PA (2001) Down-regulation of $\mathrm{mt} 1$ melatonin receptors in rat ovary following estrogen exposure. Life Sci 69:27-35.

Cogé F, Guenin SP, Fery I, Migaud M, Devavry S, Slugocki C, Legros C, Ouvry C Cohen W, Renault N, et al. (2009) The end of a myth: cloning and characterization of the ovine $\mathrm{MT}_{2}$ receptor. Br J Pharmacol 158:1248-1262.

Collins A, Yuan L, Kiefer TL, Cheng Q, Lai L, and Hill SM (2003) Overexpression of the MT1 melatonin receptor in MCF-7 human breast cancer cells inhibits mammary tumor formation in nude mice. Cancer Lett 189:49-57.

Conway S, Canning SJ, Barrett P, Guardiola-Lemaitre B, Delagrange P, and Morgan PJ (1997) The roles of valine 208 and histidine 211 in ligand binding and receptor function of the ovine Mel1a beta melatonin receptor. Biochem Biophys Res Commun 239:418-423.

Conway S, Drew JE, Mowat ES, Barrett P, Delagrange P, and Morgan PJ (2000) Chimeric melatonin $\mathrm{mt} 1$ and melatonin-related receptors. Identification of domains and residues participating in ligand binding and receptor activation of the melatonin mt1 receptor. J Biol Chem 275:20602-20609.

Conway S, Mowat ES, Drew JE, Barrett P, Delagrange P, and Morgan PJ (2001) Serine residues 110 and 114 are required for agonist binding but not antagonist binding to the melatonin MT(1) receptor. Biochem Biophys Res Commun 282 1229-1236.

Dauchy RT, Blask DE, Sauer LA, Davidson LK, Krause JA, Smith LC, and Dauchy EM (2003) Physiologic melatonin concentration, omega-3 fatty acids, and conjugated linoleic acid inhibit fatty acid transport in rodent hind limb skeletal muscle in vivo. Comp Med 53:186-190.

Davies DJ, Faust R, Garratt PJ, Marivingt-Mounir C, Kathryn Davidson, Teh MT, and Sugden D (2004) Binding affinity and biological activity of oxygen and sulfur isosteres at melatonin receptors as a function of their hydrogen bonding capability. Bioorg Chem 32:1-12.

Davies DJ, Garratt PJ, Tocher DA, Vonhoff S, Davies J, Teh MT, and Sugden D (1998) Mapping the melatonin receptor. 5. Melatonin agonists and antagonists derived from tetrahydrocyclopent $[\mathrm{b}]$ indoles, tetrahydrocarbazoles and hexahydrocyclohept[b]indoles. $J$ Med Chem 41:451-467.

Davis FC (1997) Melatonin: role in development. J Biol Rhythms 12:498-508.

Dawson D and Armstrong SM (1996) Chronobiotics-drugs that shift rhythms. Pharmacol Ther 69:15-36.

De Leersnyder H, Bresson JL, de Blois MC, Souberbielle JC, Mogenet A, Delhotal Landes B, Salefranque F, and Munnich A (2003) Beta 1-adrenergic antagonists and melatonin reset the clock and restore sleep in a circadian disorder, SmithMagenis syndrome. J Med Genet 40:74-78.

Depreux P, Lesieur D, Mansour HA, Morgan P, Howell HE, Renard P, Caignard DH Pfeiffer B, Delagrange P, and Guardiola B (1994) Synthesis and structure-activity relationships of novel naphthalenic and bioisosteric related amidic derivatives as melatonin receptor ligands. J Med Chem 37:3231-3239.

Descamps-François C, Yous S, Chavatte P, Audinot V, Bonnaud A, Boutin JA Delagrange P, Bennejean C, Renard P, and Lesieur D (2003) Design and synthesis of naphthalenic dimers as selective MT1 melatoninergic ligands. J Med Chem 46:1127-1129.

Deupi X, Dölker N, López-Rodríguez ML, Campillo M, Ballesteros JA, and Pardo L (2007) Structural models of class a G protein-coupled receptors as a tool for drug design: insights on transmembrane bundle plasticity. Curr Top Med Chem 7:991998

Dillon DC, Easley SE, Asch BB, Cheney RT, Brydon L, Jockers R, Winston JS, Brooks JS, Hurd T, and Asch HL (2002) Differential expression of high-affinity melatonin receptors (MT1) in normal and malignant human breast tissue. Am J Clin Pathol 118:451-458.

Dollins AB, Zhdanova IV, Wurtman RJ, Lynch HJ, and Deng MH (1994) Effect of inducing nocturnal serum melatonin concentrations in daytime on sleep, mood, body temperature, and performance. Proc Natl Acad Sci USA 91:1824-1828.

Doolen S, Krause DN, Dubocovich ML, and Duckles SP (1998) Melatonin mediates two distinct responses in vascular smooth muscle. Eur J Pharmacol 345:67-69.

Drazen DL, Bilu D, Bilbo SD, and Nelson RJ (2001) Melatonin enhancement of splenocyte proliferation is attenuated by luzindole, a melatonin receptor antagonist. Am J Physiol Regul Integr Comp Physiol 280:R1476-R1482.

Drazen DL and Nelson RJ (2001) Melatonin receptor subtype MT2 (Mel 1b) and not mt1 (Mel 1a) is associated with melatonin-induced enhancement of cell-mediated and humoral immunity. Neuroendocrinology 74:178-184.

Drew JE, Williams LM, Hannah LT, Barrett P, and Abramovich DR (1998) Melatonin receptors in the human fetal kidney: 2-[125I]iodomelatonin binding sites correlated with expression of Mel1a and Mel1b receptor genes. J Endocrinol 156:261-267.

Dubocovich ML (1983) Melatonin is a potent modulator of dopamine release in the retina. Nature 306:782-784

Dubocovich ML (1985) Characterization of a retinal melatonin receptor. J Pharmacol Exp Ther 234:395-401.

Dubocovich ML (1988a) Luzindole (N-0774): a novel melatonin receptor antagonist. J Pharmacol Exp Ther 246:902-910.

Dubocovich ML (1988b) Pharmacology and function of melatonin receptors. FASEB $J$ 2:2765-2773.

Dubocovich ML (1988c) Pharmacology and function of melatonin in retina, in Progress in Retinal Research (Osborne NN and Chader G eds) pp 129-151, Pergamon Press, Oxford.

Dubocovich ML (1995) Melatonin receptors: are there multiple subtypes? Trends Pharmacol Sci 16:50-56.

Dubocovich ML (2006) Agomelatine targets a range of major depressive disorder symptoms. Curr Opin Investig Drugs 7:670-680.

Dubocovich ML (2007) Melatonin receptors: role on sleep and circadian rhythm regulation. Sleep Med 8:34-42.

Dubocovich ML, Cardinali DP, Delagrange P, Krause DN, Strosberg AD, Sugden D and Yocca FD (2000) Melatonin receptors, in The IUPHAR Compendium of Recep tor Characterization and Classification, 2nd ed (Girdlestone D ed) pp 270-277, IUPHAR Media, London.

Dubocovich ML, Cardinali DP, Guardiola-Lemaitre B, Hagan RM, Krause DN, Sugden D, Vanhoutte PM and Yocca FD (1998a) Melatonin receptors, in The IUPHAR Compendium of Receptor Characterization and Classification pp 187193, IUPHAR Media, London.

Dubocovich ML, Delagrange P, and Olcese J (2009) Melatonin receptors, in IUPHAR database (IUPHAR-DB). Available at: http://www.iuphar-db.org/DATABASE/ FamilyMenuForward?familyId $=39$

Dubocovich ML, Hudson RL, Sumaya IC, Masana MI, and Manna E (2005) Effect of MT1 melatonin receptor deletion on melatonin-mediated phase shift of circadian rhythms in the C57BL/6 mouse. J Pineal Res 39:113-120.

Dubocovich ML and Masana M (2003) Melatonin receptor signaling, in Encyclopedia of Hormones and Related Cell Regulators (Henry H and Norman A eds), pp 638-644, Academic Press, San Diego, CA

Dubocovich ML and Masana MI (1998) The efficacy of melatonin receptor analogues is dependent on the level of human melatonin receptor subtype expression, in Biological Clocks Mechanisms and Applications (Touitou Y ed) pp 289-293, Elsevier Science, Amsterdam.

Dubocovich ML and Masana MI (1999) 3H-4P-PDOT: A selective MT2 melatonin (MLT) receptor antagonist radioligand. Soc Neurosci Abstr 25:351.

Dubocovich ML, Masana MI, Iacob S, and Sauri DM (1997) Melatonin receptor antagonists that differentiate between the human $\mathrm{Mel}_{1 \mathrm{a}}$ and $\mathrm{Mel}_{1 \mathrm{~b}}$ recombinan subtypes are used to assess the pharmacological profile of the rabbit retina ML presynaptic heteroreceptor. Naunyn Schmiedebergs Arch Pharmacol 355:365-375.

Dubocovich ML, Rivera-Bermudez MA, Gerdin MJ, and Masana MI (2003) Molecular pharmacology, regulation and function of mammalian melatonin receptors. Front Biosci 8:d1093-d1108.

Dubocovich ML and Takahashi JS (1987) Use of 2-[ $\left.{ }^{125} \mathrm{I}\right]$ iodomelatonin to characterize melatonin binding sites in chicken retina. Proc Natl Acad Sci USA 84:39163920 .

Dubocovich ML, Yun K, Al-Ghoul WM, Benloucif S, and Masana MI (1998b) Selective MT2 melatonin receptor antagonists block melatonin-mediated phase advances of circadian rhythms. FASEB $J$ 12:1211-1220.

Dufourny L, Levasseur A, Migaud M, Callebaut I, Pontarotti P, Malpaux B, and Monget P (2008) GPR50 is the mammalian ortholog of Mel1c: evidence of rapid evolution in mammals. BMC Evol Biol 8:105.

Duncan MJ (2007) Circannual prolactin rhythms: calendar-like timer revealed in the pituitary gland. Trends Endocrinol Metab 18:259-260.

Ebisawa T, Kajimura N, Uchiyama M, Katoh M, Sekimoto M, Watanabe T, Ozeki Y, Ikeda M, Jodoi T, Sugishita M, et al. (1999) Alleic variants of human melatonin 1a receptor: function and prevalence in subjects with circadian rhythm sleep disorders. Biochem Biophys Res Commun 262:832-837.

Ebisawa T, Karne S, Lerner MR, and Reppert SM (1994) Expression cloning of a high-affinity melatonin receptor from Xenopus dermal melanophores. Proc Natl Acad Sci USA 91:6133-6137.

Ebisawa T, Uchiyama M, Kajimura N, Kamei Y, Shibui K, Kim K, Kudo Y, Iwase T, 
Sugishita M, Jodoi T, et al. (2000) Genetic polymorphisms of human melatonin 1b receptor gene in circadian rhythm sleep disorders and controls. Neurosci Lett 280:29-32.

Ehrlich GK, Andria ML, Zheng X, Kieffer B, Gioannini TL, Hiller JM, Rosenkranz JE, Veksler BM, Zukin RS, and Simon EJ (1998) Functional significance of cysteine residues in the delta opioid receptor studied by site-directed mutagenesis. Can J Physiol Pharmacol 76:269-277.

Eison AS and Mullins UL (1993) Melatonin binding sites are functionally coupled to phosphoinositide hydrolysis in Syrian hamster RPMI 1846 melanoma cells. Life Sci 53:L393-L398.

Ekmekcioglu C, Haslmayer P, Philipp C, Mehrabi MR, Glogar HD, Grimm M, Leibetseder VJ, Thalhammer T, and Marktl W (2001a) Expression of the MT1 melatonin receptor subtype in human coronary arteries. J Recept Signal Transduct Res 21:85-91.

Ekmekcioglu C, Haslmayer P, Philipp C, Mehrabi MR, Glogar HD, Grimm M, Thalhammer T, and Marktl W (2001b) 24h variation in the expression of the mt1 melatonin receptor subtype in coronary arteries derived from patients with coronary heart disease. Chronobiol Int 18:973-985.

Erman M, Seiden D, Zammit G, Sainati S, and Zhang J (2006) An efficacy, safety, and dose-response study of Ramelteon in patients with chronic primary insomnia. Sleep Med 7:17-24.

Evans BK, Mason R, and Wilson VG (1992) Evidence for direct vasoconstrictor activity of melatonin in "pressurized" segments of isolated caudal artery from juvenile rats. Naunyn Schmiedebergs Arch Pharmacol 346:362-365.

Farce A, Chugunov AO, Logé C, Sabaouni A, Yous S, Dilly S, Renault N, Vergoten G, Efremov RG, Lesieur D, et al. (2008) Homology modelling of MT1 and MT2 receptors. Eur J Med Chem 43:1926-1944.

Faust R, Garratt PJ, Jones R, Yeh LK, Tsotinis A, Panoussopoulou M, Calogeropoulou T, Teh MT, and Sugden D (2000) Mapping the melatonin receptor. 6. Melatonin agonists and antagonists derived from $6 \mathrm{H}$-isoindolo[2,1-a]indoles, 5,6-dihydroindolo[2,1-a]isoquinolines, and 6,7-dihydro-5H-benzo[c]azepino[2,1-a]indoles. J Med Chem 43:1050-1061.

Feng Z, Chang Y, Cheng Y, Zhang BL, Qu ZW, Qin C, and Zhang JT (2004) Melatonin alleviates behavioral deficits associated with apoptosis and cholinergic system dysfunction in the APP 695 transgenic mouse model of Alzheimer's disease. $J$ Pineal Res 37:129-136.

Ferguson SS (2001) Evolving concepts in G protein-coupled receptor endocytosis: the role in receptor desensitization and signaling. Pharmacol Rev 53:1-24.

Ferry G, Ubeaud C, Lambert PH, Bertin S, Cogé F, Chomarat P, Delagrange P, Serkiz B, Bouchet JP, Truscott RJ, et al. (2005) Molecular evidence that melatonin is enzymatically oxidized in a different manner than tryptophan: investigations with both indoleamine 2,3-dioxygenase and myeloperoxidase. Biochem J 388:205215.

Fisher SP, Davidson K, Kulla A, and Sugden D (2008) Acute sleep-promoting action of the melatonin agonist, ramelteon, in the rat. J Pineal Res 45:125-132.

Frungieri MB, Mayerhofer A, Zitta K, Pignataro OP, Calandra RS, and GonzalezCalvar SI (2005) Direct effect of melatonin on Syrian hamster testes: melatonin subtype 1a receptors, inhibition of androgen production, and interaction with the local corticotropin-releasing hormone system. Endocrinology 146:1541-1552.

Fukatsu K, Uchikawa O, Kawada M, Yamano T, Yamashita M, Kato K, Hirai K, Hinuma S, Miyamoto M, and Ohkawa S (2002) Synthesis of a novel series of benzocycloalkene derivatives as melatonin receptor agonists. J Med Chem 45: 4212-4221.

Fukuhara C, Dirden JC, and Tosini G (2001) Photic regulation of melatonin in rat retina and the role of proteasomal proteolysis. Neuroreport 12:3833-3837.

Garfinkel D, Laudon M, and Zisapel N (1997) Improvement of sleep quality by controlled-release melatonin in benzodiazepine-treated elderly insomniacs. Arch Gerontol Geriatr 24:223-231.

Garratt PJ, Jones R, Tocher DA, and Sugden D (1995) Mapping the melatonin receptor. 3. Design and synthesis of melatonin agonists and antagonists derived from 2-phenyltryptamines. J Med Chem 38:1132-1139.

Garratt PJ, Travard S, Vonhoff S, Tsotinis A, and Sugden D (1996) Mapping the melatonin receptor. 4. Comparison of the binding affinities of a series of substituted phenylalkyl amides. J Med Chem 39:1797-1805.

Garratt PJ, Vonhoff S, Rowe SJ, and Sugden D (1994a) Mapping the melatonin receptor. 1 . The 5-methoxyl group of melatonin is not essential requirement for biological activity. Bioorg Med Chem Lett 4:1555-1558.

Garratt PJ, Vonhoff S, Rowe S, and Sugden D (1994b) Mapping the melatonin receptor. 2. Synthesis and biological activity of indole derived melatonin analogues with restricted conformations of the C-3 amidoethane side chain. Bioorg Med Chem Lett 4:1559-1564.

Gastel JA, Roseboom PH, Rinaldi PA, Weller JL, and Klein DC (1998) Melatonin production: proteasomal proteolysis in serotonin $\mathrm{N}$-acetyltransferase regulation. Science 279:1358-1360.

Gauer F and Craft CM (1996) Circadian regulation of hydroxyindole-Omethyltransferase mRNA levels in rat pineal and retina. Brain Res 737:99-109.

Geary GG, Duckles SP, and Krause DN (1998) Effect of melatonin in the rat tail artery: role of $\mathrm{K}+$ channels and endothelial factors. Br J Pharmacol 123:15331540.

Geary GG, Krause DN, and Duckles SP (1997) Melatonin directly constricts rat cerebral arteries through modulation of potassium channels. Am J Physiol 273: H1530-H1536.

Gerdin MJ, Masana MI, and Dubocovich ML (2004a) Melatonin-mediated regulation of human MT(1) melatonin receptors expressed in mammalian cells. Biochem Pharmacol 67:2023-2030.

Gerdin MJ, Masana MI, Ren D, Miller RJ, and Dubocovich ML (2003) Short-term exposure to melatonin differentially affects the functional sensitivity and trafficking of the hMT1 and hMT2 melatonin receptors. J Pharmacol Exp Ther 304:931939.

Gerdin MJ, Masana MI, Rivera-Bermúdez MA, Hudson RL, Earnest DJ, Gillette MU, and Dubocovich ML (2004b) Melatonin desensitizes endogenous MT2 mela- tonin receptors in the rat suprachiasmatic nucleus: relevance for defining the periods of sensitivity of the mammalian circadian clock to melatonin. FASEB $J$ 18:1646-1656.

Ghosh A and Hellewell JS (2007) A review of the efficacy and tolerability of agomelatine in the treatment of major depression. Expert Opin Investig Drugs 16:19992004.

Gillette MU and Mitchell JW (2002) Signaling in the suprachiasmatic nucleus: selectively responsive and integrative. Cell Tissue Res 309:99-107.

Glaser JA, Masana MI, and Dubocovich ML (1998) Selective $\mathrm{MT}_{2}$ melatonin receptor antagonists are inverse agonists on human $\mathrm{mt}_{1}$ melatonin receptor. FASEB $J$ 12:894.

Godson C and Reppert SM (1997) The Mel1a melatonin receptor is coupled to parallel signal transduction pathways. Endocrinology 138:397-404.

Goldsborough AS, Healy LE, Copeland NG, Gilbert DJ, Jenkins NA, Willison KR and Ashworth A (1993) Cloning, chromosomal localization and expression pattern of the POU domain gene Oct-11. Nucleic Acids Res 21:127-134.

Gray TM and Matthews BW (1984) Intrahelical hydrogen bonding of serine, threonine and cysteine residues within alpha-helices and its relevance to membranebound proteins. J Mol Biol 175:75-81.

Grol CJ and Jansen JM (1996) The high affinity melatonin binding site probed with conformationally restricted ligands-II. Homology modeling of the receptor. Bioorg Med Chem 4:1333-1339.

Gubitz AK and Reppert SM (2000) Chimeric and point-mutated receptors reveal that a single glycine residue in transmembrane domain 6 is critical for high affinity melatonin binding. Endocrinology 141:1236-1244.

Guerrero JM and Reiter RJ (2002) Melatonin-immune system relationships. Curr Top Med Chem 2:167-179.

Guilleminault C (2005) P. 2.064 Efficacy of agomelatine versus venlafaxine on subjective sleep of patients with major depressive disorder. J Eur Coll Neuropsychophamacol 15:S419-S420.

Hagan RM and Oakley NR (1995) Melatonin comes of age? Trends Pharmacol Sci 16:81-83.

Haimov I, Lavie P, Laudon M, Herer P, Vigder C, and Zisapel N (1995) Melatonin replacement therapy of elderly insomniacs. Sleep 18:598-603.

Hardeland R (2005) Antioxidative protection by melatonin: multiplicity of mecha nisms from radical detoxification to radical avoidance. Endocrine 27:119-130.

Hazlerigg DG, Gonzalez-Brito A, Lawson W, Hastings MH, and Morgan PJ (1993) Prolonged exposure to melatonin leads to time-dependent sensitization of adenylate cyclase and down-regulates melatonin receptors in pars tuberalis cells from ovine pituitary. Endocrinology 132:285-292.

Hernandez X, Bodin L, Chesneau D, Guillaume D, Allain D, Chemineau P, Malpaux B, and Migaud M (2005) Relationship between MT1 melatonin receptor gene polymorphism and seasonal physiological responses in Ile-de-France ewes. Reprod Nutr Dev 45:151-162

Heward CB and Hadley ME (1975) Structure-activity relationships of melatonin and related indoleamines. Life Sci 17:1167-1177.

Hirata F, Hayaishi O, Tokuyama T, and Seno S (1974) In vitro and in vivo formation of two new metabolites of melatonin. J Biol Chem 249:1311-1313.

Ho BY, Karschin A, Branchek T, Davidson N, and Lester HA (1992) The role of conserved aspartate and serine residues in ligand binding and in function of the 5-HT1A receptor: a site-directed mutation study. FEBS Lett 312:259-262.

Hung AY and Sheng M (2002) PDZ domains: structural modules for protein complex assembly. J Biol Chem 277:5699-5702.

Hunt AE, Al-Ghoul WM, Gillette MU, and Dubocovich ML (2001) Activation of MT(2) melatonin receptors in rat suprachiasmatic nucleus phase advances the circadian clock. Am J Physiol Cell Physiol 280:C110-C118.

Ishii H, Tanaka N, Kobayashi M, Kato M, and Sakuma Y (2009) Gene structures, biochemical characterization and distribution of rat melatonin receptors. J Physiol Sci 59:37-47.

Ivanova EA, Bechtold DA, Dupré SM, Brennand J, Barrett P, Luckman SM, and Loudon AS (2008) Altered metabolism in the melatonin-related receptor (GPR50) knockout mouse. Am J Physiol Endocrinol Metab 294:E176-E182.

Jansen JM, Copinga S, Gruppen G, Molinari EJ, Dubocovich ML, and Grol CJ (1996) The high affinity melatonin binding site probed with conformationally restricted ligand-I. Pharmacophore and minireceptor models. Bioorg Med Chem 4:13211332.

Jellimann C, Mathé-Allainmat M, Andrieux J, Kloubert S, Boutin JA, Nicolas JP, Bennejean C, Delagrange P, and Langlois M (2000) Synthesis of phenalene and acenaphthene derivatives as new conformationally restricted ligands for melatonin receptors. J Med Chem 43:4051-4062.

Jiang ZG, Nelson CS, and Allen CN (1995) Melatonin activates an outward current and inhibits Ih in rat suprachiasmatic nucleus neurons. Brain Res 687:125-132.

Jin X, von Gall C, Pieschl RL, Gribkoff VK, Stehle JH, Reppert SM, and Weaver DR (2003) Targeted disruption of the mouse Mel(1b) melatonin receptor. Mol Cell Biol 23:1054-1060

Jockers R, Maurice P, Boutin JA, and Delagrange P (2008) Melatonin receptors, heterodimerization, signal transduction and binding sites: what's new? Br J Pharmacol 154:1182-1195.

Johnston JD, Messager S, Barrett P, and Hazlerigg DG (2003a) Melatonin action in the pituitary: neuroendocrine synchronizer and developmental modulator? $J \mathrm{Neu}$ roendocrinol 15:405-408.

Johnston JD, Messager S, Ebling FJ, Williams LM, Barrett P, and Hazlerigg DG (2003b) Gonadotrophin-releasing hormone drives melatonin receptor downregulation in the developing pituitary gland. Proc Natl Acad Sci USA 100:28312835.

Johnston JD, Schuster C, Barrett P, and Hazlerigg DG (2007) Regulation of the ovine MT1 melatonin receptor promoter: interaction between multiple pituitary transcription factors at different phases of development. Mol Cell Endocrinol 268: $59-66$.

Jones MP, Melan MA, and Witt-Enderby PA (2000) Melatonin decreases cell prolif- 
eration and transformation in a melatonin receptor-dependent manner. Cancer Lett 151:133-143.

Judge R, Parry MG, Quail D, and Jacobson JG (2002) Discontinuation symptoms: comparison of brief interruption in fluoxetine and paroxetine treatment. Int Clin Psychopharmacol 17:217-225.

Kadekaro AL, Andrade LN, Floeter-Winter LM, Rollag MD, Virador V, Vieira W, and Castrucci AM (2004) MT-1 melatonin receptor expression increases the antiproliferative effect of melatonin on S-91 murine melanoma cells. J Pineal Res 36:204211.

Kanishi Y, Kobayashi Y, Noda S, Ishizuka B, and Saito K (2000) Differential growth inhibitory effect of melatonin on two endometrial cancer cell lines. J Pineal Res 28:227-233.

Kao HT, Adham N, Olsen MA, Weinshank RL, Branchek TA, and Hartig PR (1992) Site-directed mutagenesis of a single residue changes the binding properties of the serotonin 5-HT2 receptor from a human to a rat pharmacology. FEBS Lett 307: $324-328$.

Karasek M, Carrillo-Vico A, Guerrero JM, Winczyk K, and Pawlikowski M (2002) Expression of melatonin MT(1) and MT(2) receptors, and ROR alpha(1) receptor in transplantable murine Colon 38 cancer. Neuro Endocrinol Lett 23 (Suppl 1): $55-60$.

Karim A, Tolbert D, and Cao C (2006) Disposition kinetics and tolerance of escalating single doses of ramelteon, a high-affinity MT1 and MT2 melatonin receptor agonist indicated for treatment of insomnia. J Clin Pharmacol 46:140-148.

Karnik SS, Sakmar TP, Chen HB, and Khorana HG (1988) Cysteine residues 110 and 187 are essential for the formation of correct structure in bovine rhodopsin. Proc Natl Acad Sci USA 85:8459-8463.

Karsch FJ, Malpaux B, Wayne NL, and Robinson JE (1988) Characteristics of the melatonin signal that provide the photoperiodic code for timing seasonal reproduction in the ewe. Reprod Nutr Dev 28:459-472.

Kato K, Hirai K, Nishiyama K, Uchikawa O, Fukatsu K, Ohkawa S, Kawamata Y, Hinuma S, and Miyamoto M (2005) Neurochemical properties of ramelteon (TAK 375), a selective MT1/MT2 receptor agonist. Neuropharmacology 48:301-310.

Kemp DM, Ubeda M, and Habener JF (2002) Identification and functional characterization of melatonin Mel 1a receptors in pancreatic beta cells: potential role in incretin-mediated cell function by sensitization of cAMP signaling. Mol Cell Endocrinol 191:157-166.

Kennaway DJ, Blake P, and Webb HA (1989) A melatonin agonist and N-acetyl-N2 formyl-5-methoxykynurenamine accelerate the reentrainment of the melatonin rhythm following a phase advance of the light-dark cycle. Brain Res 495:349-354

Kennaway DJ, Hugel HM, Clarke S, Tjandra A, Johnson DW, Royles P, Webb HA, and Carbone F (1988) Structure-activity studies of melatonin analogues in prepubertal male rats. Aust J Biol Sci 41:393-400.

Kennaway DJ and Voultsios A (1998) Circadian rhythm of free melatonin in human plasma. J Clin Endocrinol Metab 83:1013-1015.

Kennaway DJ, Voultsios A, Varcoe TJ, and Moyer RW (2002) Melatonin in mice: rhythms, response to light, adrenergic stimulation, and metabolism. Am J Physiol Regul Integr Comp Physiol 282:R358-R365.

Kennedy SH (2005) Sexual function in remitted depressed patients following agomelatine and venlafaxine XR treatment. J Eur Coll Neuropsychopharmacol 15:S440.

Kim MJ, Kim HK, Kim BS, and Yim SV (2004) Melatonin increases cell proliferation in the dentate gyrus of maternally separated rats. J Pineal Res 37:193-197.

Klein DC (1999) Serotonin N-acetyltransferase. A personal historical perspective. Adv Exp Med Biol 460:5-16.

Klein DC (2007) Arylalkylamine N-acetyltransferase: "the Timezyme". J Biol Chem 282:4233-4237.

Kobilka BK and Deupi X (2007) Conformational complexity of G-protein-coupled receptors. Trends Pharmacol Sci 28:397-406.

Kokkola T, Salo OM, Poso A, and Laitinen JT (2005) The functional role of cysteines adjacent to the NRY motif of the human MT1 melatonin receptor. J Pineal Res 39:1-11.

Kokkola T, Vaittinen M, and Laitinen JT (2007) Inverse agonist exposure enhances ligand binding and G protein activation of the human MT1 melatonin receptor, but leads to receptor down-regulation. J Pineal Res 43:255-262.

Kokkola T, Watson MA, White J, Dowell S, Foord SM, and Laitinen JT (1998) Mutagenesis of human Mel1a melatonin receptor expressed in yeast reveals domains important for receptor function. Biochem Biophys Res Commun 249:531536.

Konopka JB, Margarit SM, and Dube P (1996) Mutation of Pro-258 in transmembrane domain 6 constitutively activates the G protein-coupled alpha-factor receptor. Proc Natl Acad Sci USA 93:6764-6769.

Kopp C, Vogel E, Rettori MC, Delagrange P, and Misslin R (1999) The effects of melatonin on the behavioural disturbances induced by chronic mild stress in C3H/He mice. Behav Pharmacol 10:73-83.

Kräuchi K, Cajochen C, Möri D, Graw P, and Wirz-Justice A (1997) Early evening melatonin and S-20098 advance circadian phase and nocturnal regulation of core body temperature. Am J Physiol 272:R1178-R1188.

Kräuchi K, Cajochen C, Werth E, and Wirz-Justice A (2000) Functional link between distal vasodilation and sleep-onset latency? Am J Physiol Regul Integr Comp Physiol 278:R741-R748.

Krause DN, Barrios VE, and Duckles SP (1995) Melatonin receptors mediate potentiation of contractile responses to adrenergic nerve stimulation in rat caudal artery. Eur $J$ Pharmacol 276:207-213.

Krause DN and Dubocovich ML (1990) Regulatory sites in the melatonin system of mammals. Trends Neurosci 13:464-470.

Krause DN and Dubocovich ML (1991) Melatonin receptors. Annu Rev Pharmacol Toxicol 31:549-568.

Krause DN, Geary GG, Doolen S, and Duckles SP (1999) Melatonin and cardiovascular function. Adv Exp Med Biol 460:299-310.

Langlois M, Brémont B, Shen S, Poncet A, Andrieux J, Sicsic S, Serraz I, MathéAllainmat M, Renard P, and Delagrange P (1995) Design and synthesis of new naphthalenic derivatives as ligands for $2-\left[{ }^{125} \mathrm{I}\right]$ iodomelatonin binding sites. J Med Chem 38:2050-2060.

Laudon M and Zisapel N (1986) Characterization of central melatonin receptors using 125I-melatonin. FEBS Lett 197:9-12.

Le Gouic S, Delagrange P, Atgié C, Nibbelink M, Hanoun N, Casteilla L, Renard P, Lesieur D, Guardiola-Lemaitre B, and Ambid L (1996) Effects of both a melatonin agonist and antagonist on seasonal changes in body mass and energy intake in the garden dormouse. Int $J$ Obes Relat Metab Disord 20:661-667.

Le Gouill C, Parent JL, Rola-Pleszczynski M, and Stanková J (1997) Role of the Cys90, Cys95 and Cys173 residues in the structure and function of the human platelet-activating factor receptor. FEBS Lett 402:203-208.

Leclerc V, Fourmaintraux E, Depreux P, Lesieur D, Morgan P, Howell HE, Renard P, Caignard DH, Pfeiffer B, Delagrange P, et al. (1998) Synthesis and structureactivity relationships of novel naphthalenic and bioisosteric related amidic derivatives as melatonin receptor ligands. Bioorg Med Chem 6:1875-1887.

Leger D, Laudon M, and Zisapel N (2004) Nocturnal 6-sulfatoxymelatonin excretion in insomnia and its relation to the response to melatonin replacement therapy. Am J Med 116:91-95.

Lerner AB, Case JD, and Heinzelman RV (1959) Structure of melatonin. J Am Chem Soc 81:6084-6085.

Levoye A, Dam J, Ayoub MA, Guillaume JL, Couturier C, Delagrange P, and Jockers R (2006a) The orphan GPR50 receptor specifically inhibits MT1 melatonin receptor function through heterodimerization. EMBO J 25:3012-3023.

Levoye A, Jockers R, Ayoub MA, Delagrange P, Savaskan E, and Guillaume JL (2006b) Are G protein-coupled receptor heterodimers of physiological relevance? Focus on melatonin receptors. Chronobiol Int 23:419-426.

Liu C, Weaver DR, Jin X, Shearman LP, Pieschl RL, Gribkoff VK, and Reppert SM (1997) Molecular dissection of two distinct actions of melatonin on the suprachiasmatic circadian clock. Neuron 19:91-102.

Lôo H, Daléry J, Macher JP, and Payen A (2003) [Pilot study comparing in blind the therapeutic effect of two doses of agomelatine, melatonin-agonist and selective 5 HT2c receptors antagonist, in the treatment of major depressive disorders.] Encephale 29:165-171.

Lôo H, Hale A, and D'haenen H (2002) Determination of the dose of agomelatine, a melatoninergic agonist and selective 5-HT(2C) antagonist, in the treatment of major depressive disorder: a placebo-controlled dose range study. Int Clin Psychopharmacol 17:239-247.

Lotufo CM, Lopes C, Dubocovich ML, Farsky SH, and Markus RP (2001) Melatonin and $\mathrm{N}$-acetylserotonin inhibit leukocyte rolling and adhesion to rat microcirculation. Eur J Pharmacol 430:351-357.

Lucchelli A, Santagostino-Barbone MG, and Tonini M (1997) Investigation into the contractile response of melatonin in the guinea-pig isolated proximal colon: the role of 5-HT4 and melatonin receptors. Br J Pharmacol 121:1775-1781.

Lyssenko V, Nagorny CL, Erdos MR, Wierup N, Jonsson A, Spégel P, Bugliani M, Saxena R, Fex M, Pulizzi N, et al. (2009) Common variant in MTNR1B associated with increased risk of type 2 diabetes and impaired early insulin secretion. Nat Genet 41:82-88.

Ma X, Chen C, Krausz KW, Idle JR, and Gonzalez FJ (2008) A metabolomic perspective of melatonin metabolism in the mouse. Endocrinology 149:1869-1879.

MacKenzie RS, Melan MA, Passey DK, and Witt-Enderby PA (2002) Dual couplin of MT(1) and MT(2) melatonin receptors to cyclic AMP and phosphoinositide signa transduction cascades and their regulation following melatonin exposure. Biochem Pharmacol 63:587-595.

Maestroni GJ (2001) The immunotherapeutic potential of melatonin. Expert Opin Investig Drugs 10:467-476.

Mahle CD, Goggins GD, Agarwal P, Ryan E, and Watson AJ (1997) Melatonin modulates vascular smooth muscle tone. J Biol Rhythms 12:690-696.

Mailliet F, Ferry G, Vella F, Thiam K, Delagrange P, and Boutin JA (2004) Organs from mice deleted for NRH:quinone oxidoreductase 2 are deprived of the melatonin binding site MT3. FEBS Lett 578:116-120.

Malpaux B, Migaud M, Tricoire H, and Chemineau P (2001) Biology of mammalian photoperiodism and the critical role of the pineal gland and melatonin. J Bio Rhythms 16:336-347.

Malpaux B, Thiéry JC, and Chemineau P (1999) Melatonin and the seasonal control of reproduction. Reprod Nutr Dev 39:355-366.

Martin JE, McKellar S, and Klein DC (1980) Melatonin inhibition of the in vivo pituitary response to luteinizing hormone-releasing hormone in the neonatal rat. Neuroendocrinology 31:13-17.

Masana MI, Doolen S, Ersahin C, Al-Ghoul WM, Duckles SP, Dubocovich ML, and Krause DN (2002) MT(2) melatonin receptors are present and functional in rat caudal artery. J Pharmacol Exp Ther 302:1295-1302.

Masana MI, Benloucif S, and Dubocovich ML (2000) Circadian rhythm of mt1 melatonin receptor expression in the suprachiasmatic nucleus of the $\mathrm{C} 3 \mathrm{H} / \mathrm{HeN}$ mouse. J Pineal Res 28:185-192.

Masana MI and Dubocovich ML (2001) Melatonin receptor signaling: finding the path through the dark. Sci STKE 2001:pe39.

Mason R and Brooks A (1988) The electrophysiological effects of melatonin and a putative melatonin antagonist (N-acetyltryptamine) on rat suprachiasmatic neurones in vitro. Neurosci Lett 95:296-301.

Mathé-Allainmat M, Gaudy F, Sicsic S, Dangy-Caye AL, Shen S, Brémont B, Benatalah Z, Langlois M, Renard P, and Delagrange P (1996) Synthesis of 2-amido-2,3dihydro-1H-phenalene derivatives as new conformationally restricted ligands for melatonin receptors. $J$ Med Chem 39:3089-3095.

Mattson RJ, Catt JD, Keavy D, Sloan CP, Epperson J, Gao Q, Hodges DB, Iben L, Mahle CD, Ryan E, et al. (2003) Indanyl piperazines as melatonergic MT2 selective agents. Bioorg Med Chem Lett 13:1199-1202.

Mazna P, Berka K, Jelinkova I, Balik A, Svoboda P, Obsilova V, Obsil T, and Teisinger J (2005) Ligand binding to the human MT2 melatonin receptor: the role of residues in transmembrane domains 3,6, and 7. Biochem Biophys Res Commun 332:726-734.

Mazna P, Grycova L, Balik A, Zemkova H, Friedlova E, Obsilova V, Obsil T, and 
Teisinger $J$ (2008) The role of proline residues in the structure and function of human MT2 melatonin receptor. J Pineal Res 45:361-372.

Mazna P, Obsilova V, Jelinkova I, Balik A, Berka K, Sovova Z, Ettrich R, Svoboda P, Obsil T, and Teisinger J (2004) Molecular modeling of human MT2 melatonin receptor: the role of Val204, Leu272 and Tyr298 in ligand binding. J Neurochem 91:836-842.

Mazzucchelli C, Pannacci M, Nonno R, Lucini V, Fraschini F, and Stankov BM (1996) The melatonin receptor in the human brain: cloning experiments and distribution studies. Brain Res Mol Brain Res 39:117-126.

McArthur AJ, Hunt AE, and Gillette MU (1997) Melatonin action and signal transduction in the rat suprachiasmatic circadian clock: activation of protein kinase $\mathrm{C}$ at dusk and dawn. Endocrinology 138:627-634.

Meier PJ, Ziegler WH, and Neftel K (1988) [Benzodiazepine-practice and problems of its use.] Schweizerische medizinische Wochenschrift 118:381-392.

Messer LA, Wang L, Tuggle CK, Yerle M, Chardon P, Pomp D, Womack JE, Barendse W, Crawford AM, Notter DR, et al. (1997) Mapping of the melatonin receptor 1a (MTNR1A) gene in pigs, sheep, and cattle. Mamm Genome 8:368-370.

Millan MJ, Gobert A, Lejeune F, Dekeyne A, Newman-Tancredi A, Pasteau V, Rivet JM, and Cussac D (2003) The novel melatonin agonist agomelatine (S20098) is an antagonist at 5-hydroxytryptamine $2 \mathrm{C}$ receptors, blockade of which enhances the activity of frontocortical dopaminergic and adrenergic pathways. J Pharmacol Exp Ther 306:954-964.

Mills KA, Buetow KH, Xu Y, Ritty TM, Mathews KD, Bodrug SE, Wijmenga C, Balazs I, and Murray JC (1992) Genetic and physical mapping on chromosome 4 narrows the localization of the gene for facioscapulohumeral muscular dystrophy (FSHD). Am J Hum Genet 51:432-439.

Miyamoto M (2009) Pharmacology of ramelteon, a selective MT1/MT2 receptor agonist: a novel therapeutic drug for sleep disorders. CNS Neurosci Ther 15:32-51.

Miyamoto M, Nishikawa H, Doken Y, Hirai K, Uchikawa O, and Ohkawa S (2004) The sleep-promoting action of ramelteon (TAK-375) in freely moving cats. Sleep 27:1319-1325

Molinari EJ, North PC, and Dubocovich ML (1996) 2-[ $\left.{ }^{125} \mathrm{I}\right]$ iodo-5-methoxycarbonylamino-N-acetyltryptamine: a selective radioligand for the characterization of melatonin ML2 binding sites. Eur J Pharmacol 301:159-168.

Montgomery SA and Kasper S (2007) Severe depression and antidepressants: focus on a pooled analysis of placebo-controlled studies on agomelatine. Int Clin Psychopharmacol 22:283-291.

Montgomery SA, Kennedy SH, Burrows GD, Lejoyeux M, and Hindmarch I (2004) Absence of discontinuation symptoms with agomelatine and occurrence of discontinuation symptoms with paroxetine: a randomized, double-blind, placebocontrolled discontinuation study. Int Clin Psychopharmacol 19:271-280.

Monti JM and Cardinali DP (2000) A critical assessment of the melatonin effect on sleep in humans. Biol Signals Recept 9:328-339.

Mor M, Plazzi PV, Spadoni G, and Tarzia G (1999) Melatonin. Curr Med Chem 6:501-518

Mor M, Rivara S, Silva C, Bordi F, Plazzi PV, Spadoni G, Diamantini G, Balsamini C, Tarzia G, Fraschini F, et al. (1998) Melatonin receptor ligands: synthesis of new melatonin derivatives and comprehensive comparative molecular field analysis (CoMFA) study. J Med Chem 41:3831-3844.

Morgan PJ, Barrett P, Howell HE, and Helliwell R (1994b) Melatonin receptors: localization, molecular pharmacology and physiological significance. Neurochem Int 24:101-146.

Morin D, Simon N, Deprés-Brummer P, Lévi F, Tillement JP, and Urien S. Simon, P. Depresbrummer, F. Levi, J. P. Tillement, and S. Urien (1997) Melatonin high-affinity binding to alpha-1-acid glycoprotein in human serum. Pharmacology 54:271-275.

Moriya T, Horie N, Mitome M, and Shinohara K (2007) Melatonin influences the proliferative and differentiative activity of neural stem cells. J Pineal Res 42:411418.

Mseeh F, Gerdin MJ, and Dubocovich MI (2002) Identification of cysteines involved in ligand binding to the human melatonin MT(2) receptor. Eur J Pharmacol 449:29-38

Mühlbauer E, Gross E, Labucay K, Wolgast S, and Peschke E (2009) Loss of melatonin signalling and its impact on circadian rhythms in mouse organs regulating blood glucose. Eur $J$ Pharmacol 606:61-71.

Mühlbauer E and Peschke E (2007) Evidence for the expression of both the MT1- and in addition, the MT2-melatonin receptor, in the rat pancreas, islet and beta-cell. $J$ Pineal Res 42:105-106.

Mulchahey JJ, Goldwater DR, and Zemlan FP (2004) A single blind, placebo controlled, across groups dose escalation study of the safety, tolerability, pharmacokinetics and pharmacodynamics of the melatonin analog beta-methyl-6chloromelatonin. Life Sci 75:1843-1856.

Mulder H, Nagorny CL, Lyssenko V, and Groop L (2009) Melatonin receptors in pancreatic islets: good morning to a novel type 2 diabetes gene. Diabetologia 52:1240-1249.

Naji L, Carrillo-Vico A, Guerrero JM, and Calvo JR (2004) Expression of membrane and nuclear melatonin receptors in mouse peripheral organs. Life Sci 74:22272236.

Navajas C, Kokkola T, Poso A, Honka N, Gynther J, and Laitinen JT (1996) A rhodopsin-based model for melatonin recognition at its $\mathrm{G}$ protein-coupled receptor. Eur J Pharmacol 304:173-183.

Nelson CS, Ikeda M, Gompf HS, Robinson ML, Fuchs NK, Yoshioka T, Neve KA, and Allen CN (2001) Regulation of melatonin 1a receptor signaling and trafficking by asparagine-124. Mol Endocrinol 15:1306-1317.

Nelson CS, Marino JL, and Allen CN (1996) Melatonin receptors activate heteromeric G-protein coupled Kir3 channels. Neuroreport 7:717-720.

Nelson MT and Quayle JM (1995) Physiological roles and properties of potassium channels in arterial smooth muscle. Am J Physiol 268:C799-C822.

New DC, Tsim ST, and Wong YH (2003) G protein-linked effector and second messenger systems involved in melatonin signal transduction. Neurosignals 12: $59-70$.
Niles LP, Wang J, Shen L, Lobb DK, and Younglai EV (1999) Melatonin receptor mRNA expression in human granulosa cells. Mol Cell Endocrinol 156:107-110.

Nishiyama K, Shintani Y, Hirai K, and Yoshikubo S (2009) Molecular cloning and pharmacological characterization of monkey MT1 and MT2 melatonin receptors showing high affinity for the agonist ramelteon. J Pharmacol Exp Ther 330:855863.

Noda K, Saad Y, Graham RM, and Karnik SS (1994) The high affinity state of the beta 2 -adrenergic receptor requires unique interaction between conserved and non-conserved extracellular loop cysteines. J Biol Chem 269:6743-6752.

Nonno R, Lucini V, Spadoni G, Pannacci M, Croce A, Esposti D, Balsamini C, Tarzia G, Fraschini F, and Stankov BM (2000) A new melatonin receptor ligand with mt1-agonist and MT2-antagonist properties. J Pineal Res 29:234-240.

Nonno R, Pannacci M, Lucini V, Angeloni D, Fraschini F, and Stankov BM (1999) Ligand efficacy and potency at recombinant human MT2 melatonin receptors: evidence for agonist activity of some mt1-antagonists. Br J Pharmacol 127:12881294.

Nosjean O, Ferro M, Coge F, Beauverger P, Henlin JM, Lefoulon F, Fauchere JL, Delagrange P, Canet E, and Boutin JA (2000) Identification of the melatonin binding site MT3 as the quinone reductase 2. J Biol Chem 275:31311-31317.

Nosjean O, Nicolas JP, Klupsch F, Delagrange P, Canet E, and Boutin JA (2001) Comparative pharmacological studies of melatonin receptors: MT1, MT2 and MT3/QR2. Tissue distribution of MT3/QR2. Biochem Pharmacol 61:1369-1379.

Olcese J ed (1999) Melatonin after Four Decades: An Assessment of its Potential, Kluwer Academic/Plenum Publishers, New York.

Olcese JM, Cao C, Mori T, Mamcarz MB, Maxwell A, Runfeldt MJ, Wang L, Zhang C, Lin X, Zhang G, et al. (2009) Protection against cognitive deficits and markers of neurodegeneration by long-term oral administration of melatonin in a transgenic model of Alzheimer disease. J Pineal Res 47:82-96.

Olié JP and Kasper S (2007) Efficacy of agomelatine, a MT1/MT2 receptor agonist with 5-HT2C antagonistic properties, in major depressive disorder. Int $J$ Neuropsychopharmacol 10:661-673.

Ono H, Hoshino Y, Yasuo S, Watanabe M, Nakane Y, Murai A, Ebihara S, Korf HW and Yoshimura T (2008) Involvement of thyrotropin in photoperiodic signal transduction in mice. Proc Natl Acad Sci USA 105:18238-18242.

Ozaki Y and Lynch HJ (1976) Presence of melatonin in plasma and urine or pinealectomized rats. Endocrinology 99:641-644.

Pardridge WM and Mietus LJ (1980) Transport of albumin-bound melatonin through the blood-brain barrier. J Neurochem 34:1761-1763.

Pawlikowski M, Winczyk K, and Karasek M (2002) Oncostatic action of melatonin: facts and question marks. Neuro Endocrinol Lett 23 (Suppl 1):24-29.

Pelletier J, Bodin L, Hanocq E, Malpaux B, Teyssier J, Thimonier J, and Chemineau P (2000) Association between expression of reproductive seasonality and alleles of the gene for Mel(1a) receptor in the ewe. Biol Reprod 62:1096-1101.

Peschke E, Fauteck JD, Musshoff U, Schmidt F, Beckmann A, and Peschke D (2000) Evidence for a melatonin receptor within pancreatic islets of neonate rats: func tional, autoradiographic, and molecular investigations. J Pineal Res 28:156-164.

Peschke E, Mühlbauer E, Musshoff U, Csernus VJ, Chankiewitz E, and Peschke D (2002) Receptor (MT(1)) mediated influence of melatonin on cAMP concentration and insulin secretion of rat insulinoma cells INS-1. J Pineal Res 33:63-71.

Peschke E, Stumpf I, Bazwinsky I, Litvak L, Dralle H, and Mühlbauer E (2007) Melatonin and type 2 diabetes - a possible link? J Pineal Res 42:350-358.

Petit L, Lacroix I, de Coppet P, Strosberg AD, and Jockers R (1999) Differential signaling of human Mel1a and Mel1b melatonin receptors through the cyclic guanosine $3^{\prime}-5^{\prime}$-monophosphate pathway. Biochem Pharmacol 58:633-639.

Pickering DS and Niles LP (1990) Pharmacological characterization of melatonin binding sites in Syrian hamster hypothalamus. Eur J Pharmacol 175:71-77.

Pitrosky B, Delagrange P, Rettori MC, and Pévet P (2003) S22153, a melatonin antagonist, dissociates different aspects of photoperiodic responses in Syrian hamsters. Behav Brain Res 138:145-152.

Pitrosky B, Masson-Pevet M, Kirsch R, Vivien-Roels B, Canguilhem B, and Pévet P (1991) Effects of different doses and durations of melatonin infusions on plasma melatonin concentrations in pinealectomized Syrian hamsters: consequences at the level of sexual activity. J Pineal Res 11:149-155

Poirel VJ, Masson-Pévet M, Pevét P, and Gauer F (2002) MT1 melatonin receptor mRNA expression exhibits a circadian variation in the rat suprachiasmatic nuclei. Brain Res 946:64-71.

Popova JS and Dubocovich ML (1995) Melatonin receptor-mediated stimulation of phosphoinositide breakdown in chick brain slices. J Neurochem 64:130-138.

Prokopenko I, Langenberg C, Florez JC, Saxena R, Soranzo N, Thorleifsson G, Loos RJ, Manning AK, Jackson AU, Aulchenko Y, et al. (2009) Variants in MTNR1B influence fasting glucose levels. Nat Genet 41:77-81.

Quay WB (1968) Individualization and lack of pineal effect in the rat's circadian locomotor rhythm. Physiol Behav 3:109-118.

Quay WB (1970a) Physiological significance of the pineal during adaptation to shifts in photoperiod. Physiol Behav 5:353-360.

Quay WB (1970b) Precocious entrainment and associated characteristics of activity patterns following pinalectomy and reversal of photoperiod. Physiol Behav 5:12811290.

Quera-Salva M, Vanier B, Chapotot F, Bohic M, Moulin C, Lofaso F, and Guilleminault C (2005) P. 2.102 Effect of agomelatine on the sleep EEG in patients with major depressive disorder (MMD). J Eur Coll Neuropsychopharmacol 15:S435S436.

Racagni G, Riva MA, and Popoli M (2007) The interaction between the internal clock and antidepressant efficacy. Int Clin Psychopharmacol 22:S9-S14.

Radio NM, Doctor JS, and Witt-Enderby PA (2006) Melatonin enhances alkaline phosphatase activity in differentiating human adult mesenchymal stem cells grown in osteogenic medium via MT2 melatonin receptors and the MEK/ERK (1/2) signaling cascade. J Pineal Res 40:332-342.

Ram PT, Dai J, Yuan L, Dong C, Kiefer TL, Lai L, and Hill SM (2002) Involvement of the mt1 melatonin receptor in human breast cancer. Cancer Lett 179:141-150 Ramírez-Rodríguez G, Klempin F, Babu H, Benítez-King G, and Kempermann G 
(2009) Melatonin modulates cell survival of new neurons in the hippocampus of adult mice. Neuropsychopharmacology 34:2180-2191.

Redman JR (1997) Circadian entrainment and phase shifting in mammals with melatonin. J Biol Rhythms 12:581-587.

Régrigny O, Delagrange P, Scalbert E, Atkinson J, and Lartaud-Idjouadiene I (1998) Melatonin improves cerebral circulation security margin in rats. Am J Physiol 275:H139-H144

Reiter RJ (1980) The pineal and its hormones in the control of reproduction in mammals. Endocr Rev 1:109-131.

Reiter RJ (1991) Pineal melatonin: cell biology of its synthesis and its physiological interactions. Endocr Rev 12:151-180.

Reiter RJ, Tan DX, Burkhardt S, and Manchester LC (2001) Melatonin in plants. Nutr Rev 59:286-290.

Reppert SM, Godson C, Mahle CD, Weaver DR, Slaugenhaupt SA, and Gusella JF (1995a) Molecular characterization of a second melatonin receptor expressed in human retina and brain: the $\mathrm{Mel}_{1 \mathrm{~b}}$ melatonin receptor. Proc Natl Acad Sci USA 92:8734-8738.

Reppert SM and Weaver DR (1995) Melatonin madness. Cell 83:1059-1062.

Reppert SM, Weaver DR, Cassone VM, Godson C, and Kolakowski LF Jr (1995b) Melatonin receptors are for the birds: molecular analysis of two receptor subtypes differentially expressed in chick brain. Neuron 15:1003-1015.

Reppert SM, Weaver DR, and Ebisawa T (1994) Cloning and characterization of a mammalian melatonin receptor that mediates reproductive and circadian re sponses. Neuron 13:1177-1185.

Reppert SM, Weaver DR, and Godson C (1996) Melatonin receptors step into the light: cloning and classification of subtypes. Trends Pharmacol Sci 17:100-102.

Reppert SM, Weaver DR, Rivkees SA, and Stopa EG (1988) Putative melatonin receptors in a human biological clock. Science 242:78-81.

Rivara S, Mor M, Silva C, Zuliani V, Vacondio F, Spadoni G, Bedini A, Tarzia G, Lucini V, Pannacci M, et al. (2003) Three-dimensional quantitative structureactivity relationship studies on selected MT1 and MT2 melatonin receptor ligands: requirements for subtype selectivity and intrinsic activity modulation. J Med Chem 46:1429-1439.

Rivera-Bermúdez MA, Masana MI, Brown GM, Earnest DJ, and Dubocovich ML (2004) Immortalized cells from the rat suprachiasmatic nucleus express functional melatonin receptors. Brain Res 1002:21-27.

Roca AL, Godson C, Weaver DR, and Reppert SM (1996) Structure, characterization, and expression of the gene encoding the mouse Mel1a melatonin receptor [published erratum appears in Endocrinology 138:2307, 1997]. Endocrinology 137 3469-3477.

Roka F, Brydon L, Waldhoer M, Strosberg AD, Freissmuth M, Jockers R, and Nanof C (1999) Tight association of the human Mel(1a)-melatonin receptor and G(i): precoupling and constitutive activity. Mol Pharmacol 56:1014-1024.

Rönnberg L, Kauppila A, Leppäluoto J, Martikainen H, and Vakkuri O (1990 Circadian and seasonal variation in human preovulatory follicular fluid melatonin concentration. J Clin Endocrinol Metab 71:492-496.

Roseboom PH, Coon SL, Baler R, McCune SK, Weller JL, and Klein DC (1996) Melatonin synthesis: analysis of the more than 150-fold nocturnal increase in serotonin $N$-acetyltransferase messenger ribonucleic acid in the rat pineal gland. Endocrinology 137:3033-3045.

Rosenbaum DM, Cherezov V, Hanson MA, Rasmussen SG, Thian FS, Kobilka TS, Choi HJ, Yao XJ, Weis WI, Stevens RC, et al. (2007) GPCR engineering yield high-resolution structural insights into beta2-adrenergic receptor function. Science 318:1266-1273.

Roy D, Angelini NL, Fujieda H, Brown GM, and Belsham DD (2001) Cyclical regulation of $\mathrm{GnRH}$ gene expression in GT1-7 GnRH-secreting neurons by melatonin. Endocrinology 142:4711-4720.

Ruffolo R, Humphrey P, Watson S and Spedding M (2000) Revised NC-IUPHAR recommendations for nomenclature of receptors, in The IUPHAR Compendium of Receptor Characterization and Classification (Ruffolo $\mathrm{R}$ ed) pp 7-8, IUPHAR Media, London, UK.

Sallinen P, Saarela S, Ilves M, Vakkuri O, and Leppäluoto J (2005) The expression of MT1 and MT2 melatonin receptor mRNA in several rat tissues. Life Sci $\mathbf{7 6}$ $1123-1134$

Sánchez-Barceló EJ, Cos S, Fernández R, and Mediavilla MD (2003) Melatonin and mammary cancer: a short review. Endocr Relat Cancer 10:153-159.

Savaskan E, Ayoub MA, Ravid R, Angeloni D, Fraschini F, Meier F, Eckert A Müller-Spahn F, and Jockers R (2005) Reduced hippocampal MT2 melatonin receptor expression in Alzheimer's disease. J Pineal Res 38:10-16.

Savaskan E, Jockers R, Ayoub M, Angeloni D, Fraschini F, Flammer J, Eckert A Müller-Spahn F, and Meyer P (2007) The MT2 melatonin receptor subtype is present in human retina and decreases in Alzheimer's disease. Curr Alzheimer Res 4:47-51

Savaskan E, Olivieri G, Brydon L, Jockers R, Kräuchi K, Wirz-Justice A, and Müller-Spahn F (2001) Cerebrovascular melatonin MT1-receptor alterations in patients with Alzheimer's disease. Neurosci Lett 308:9-12.

Savaskan E, Olivieri G, Meier F, Brydon L, Jockers R, Ravid R, Wirz-Justice A, and Müller-Spahn F (2002b) Increased melatonin 1a-receptor immunoreactivity in the hippocampus of Alzheimer's disease patients. J Pineal Res 32:59-62.

Savaskan E, Wirz-Justice A, Olivieri G, Pache M, Kräuchi K, Brydon L, Jockers R, Müller-Spahn F, and Meyer P (2002a) Distribution of melatonin MT1 receptor immunoreactivity in human retina. J Histochem Cytochem 50:519-526.

Schaeffer HJ and Sirotkin AV (1995) Melatonin and serotonin directly regulate oxytocin, insulin-like growth factor-I and progesterone secretion by cultured human granulosa cells. Adv Exp Med Biol 395:547-548

Scher J, Wankiewicz E, Brown GM, and Fujieda H (2002) MT(1) melatonin receptor in the human retina: expression and localization. Invest Ophthalmol Vis Sci 43:889-897.

Scher J, Wankiewicz E, Brown GM, and Fujieda H (2003) AII amacrine cells express the MT1 melatonin receptor in human and macaque retina. Exp Eye Res 77:375382 .
Schlabritz-Loutsevitch N, Hellner N, Middendorf R, Müller D, and Olcese J (2003 The human myometrium as a target for melatonin. $J$ Clin Endocrinol Metab 88:908-913.

Schuster C, Gauer F, Malan A, Recio J, Pévet P, and Masson-Pévet M (2001) The circadian clock, light/dark cycle and melatonin are differentially involved in the expression of daily and photoperiodic variations in $\mathrm{mt}(1)$ melatonin receptors in the Siberian and Syrian hamsters. Neuroendocrinology 74:55-68.

Seldin MF, Saunders AM, Rochelle JM, and Howard TA (1991) A proximal mouse chromosome 9 linkage map that further defines linkage groups homologous with segments of human chromosomes 11, 15, and 19. Genomics 9:678-685.

Sharkey $J$ and Olcese $J(2007)$ Transcriptional inhibition of oxytocin receptor expression in human myometrial cells by melatonin involves protein kinase C signaling. J Clin Endocrinol Metab 92:4015-4019.

Sharkey JT, Puttaramu R, Word RA, and Olcese J (2009) Melatonin synergizes with oxytocin to enhance contractility of human myometrial smooth muscle cells. J Clin Endocrinol Metab 94:421-427.

Shibata S, Cassone VM, and Moore RY (1989) Effects of melatonin on neuronal activity in the rat suprachiasmatic nucleus in vitro. Neurosci Lett 97:140-144.

Shiu SY, Li L, Siu SW, Xi SC, Fong SW, and Pang SF (2000) Biological basis and possible physiological implications of melatonin receptor-mediated signaling in the rat epididymis. Biol Signals Recept 9:172-187.

Shiu SY, Li L, Xu JN, Pang CS, Wong JT, and Pang SF (1999) Melatonin-induced inhibition of proliferation and G1/S cell cycle transition delay of human choriocarcinoma JAr cells: possible involvement of $\mathrm{MT}_{2}$ (MEL1B) receptor. J Pineal Res 27:183-192.

Simonneaux V and Ribelayga C (2003) Generation of the melatonin endocrine message in mammals: a review of the complex regulation of melatonin synthesis by norepinephrine, peptides, and other pineal transmitters. Pharmacol Rev 55:325396

Siuciak JA, Fang JM, and Dubocovich ML (1990) Autoradiographic localization of $2-\left[{ }^{125} \mathrm{I}\right]$ iodomelatonin binding sites in the brains of $\mathrm{C} 3 \mathrm{H} / \mathrm{HeN}$ and $\mathrm{C} 57 \mathrm{BL} / 6$. strains of mice. Eur J Pharmacol 180:387-390.

Skwarlo-Sonta K, Majewski P, Markowska M, Oblap R, and Olszanska B (2003) Bidirectional communication between the pineal gland and the immune system. Can J Physiol Pharmacol 81:342-349.

Slanar O, Pelisek V, and Vanecek J (2000) Melatonin inhibits pituitary adenylyl cyclase-activating polypeptide-induced increase of cyclic AMP accumulation and $\left[\mathrm{Ca}^{2+}\right]_{\mathrm{i}}$ in cultured cells of neonatal rat pituitary. Neurochem Int 36:213-219.

Slaugenhaupt SA, Roca AL, Liebert CB, Altherr MR, Gusella JF, and Reppert SM (1995) Mapping of the gene for the Mel1a-melatonin receptor to human chromosome 4 (MTNR1A) and mouse chromosome 8 (Mtnr1a), Genomics 27:355-357.

Soares JM Jr, Masana MI, Erşahin C, and Dubocovich ML (2003) Functional melatonin receptors in rat ovaries at various stages of the estrous cycle. J Pharmacol Exp Ther 306:694-702.

Song Y, Chan CW, Brown GM, Pang SF, and Silverman M (1997) Studies of the renal action of melatonin: evidence that the effects are mediated by $37 \mathrm{kDa}$ receptors of the Mel1a subtype localized primarily to the basolateral membrane of the proximal tubule. FASEB J 11:93-100.

Spadoni G, Balsamini C, Diamantini G, Di Giacomo B, Tarzia G, Mor M, Plazzi PV, Rivara S, Lucini V, Nonno R, et al. (1997) Conformationally restrained melatonin analogues: synthesis, binding affinity for the melatonin receptor, evaluation of the biological activity, and molecular modeling study. J Med Chem 40:1990-2002.

Spadoni G, Balsamini C, Diamantini G, Tontini A, Tarzia G, Mor M, Rivara S, Plazz PV, Nonno R, Lucini V, et al. (2001) 2-N-acylaminoalkylindoles: design and quantitative structure-activity relationship studies leading to MT2-selective melatonin antagonists. J Med Chem 44:2900-2912.

Spadoni G, Stankov B, Duranti A, Biella G, Lucini V, Salvatori A, and Fraschini F (1993) 2-Substituted 5-methoxy-N-acyltryptamines: synthesis, binding affinity for the melatonin receptor, and evaluation of the biological activity. J Med Chem 36:4069-4074

Steffens F, Zhou XB, Sausbier U, Sailer C, Motejlek K, Ruth P, Olcese J, Korth M, and Wieland T (2003) Melatonin receptor signaling in pregnant and nonpregnan rat uterine myocytes as probed by large conductance $\mathrm{Ca} 2+$-activated $\mathrm{K}+$ channel activity. Mol Endocrinol 17:2103-2115.

Stefulj J, Hörtner M, Ghosh M, Schauenstein K, Rinner I, Wölfler A, Semmler J, and Liebmann PM (2001) Gene expression of the key enzymes of melatonin synthesis in extrapineal tissues of the rat. J Pineal Res 30:243-247.

Stehle J, Vanecek J, and Vollrath L (1989) Effects of melatonin on spontaneous electrical activity of neurons in rat suprachiasmatic nuclei: an in vitro iontophoretic study. J Neural Transm 78:173-177.

Strader CD, Candelore MR, Hill WS, Sigal IS, and Dixon RA (1989) Identification of two serine residues involved in agonist activation of the beta-adrenergic receptor. $J$ Biol Chem 264:13572-13578.

Stumpf I, Mühlbauer E, and Peschke E (2008) Involvement of the cGMP pathway in mediating the insulin-inhibitory effect of melatonin in pancreatic beta-cells. $J$ Pineal Res 45:318-327.

Stumpf I, Bazwinsky I, and Peschke E (2009) Modulation of the cGMP signaling pathway by melatonin in pancreatic beta-cells. J Pineal Res 46:140-147.

Sugden D (1989) Melatonin analogues induce pigment granule condensation in isolated Xenopus laevis melanophores in tissue culture. J Endocrinol 120:R1-R3 Sugden D (1994) Melatonin: binding site characteristics and biochemical and cellular responses. Neurochem Int 24:147-157.

Sugden D, Chong NW, and Lewis DF (1995) Structural requirements at the melatonin receptor. $B r$ J Pharmacol 114:618-623.

Sugden D, Davidson K, Hough KA, and Teh MT (2004) Melatonin, melatonin receptors and melanophores: a moving story. Pigment Cell Res 17:454-460.

Sugden D, Pickering H, Teh MT, and Garratt PJ (1997) Melatonin receptor pharmacology: toward subtype specificity. Biol Cell 89:531-537.

Sugden D and Rowe SJ (1994) 2-Iodo-N-butanoyl-5-methoxytryptamine: a potent melatonin receptro agonist. Pharmacol Commun 4:267-276. 
Sugden D, Yeh LK, and Teh MT (1999) Design of subtype selective melatonin receptor agonists and antagonists. Reprod Nutr Dev 39:335-344.

Sumaya IC, Masana MI, and Dubocovich ML (2005) The antidepressant-like effect of the melatonin receptor ligand luzindole in mice during forced swimming requires expression of MT2 but not MT1 melatonin receptors. J Pineal Res 39:170-177.

Tamarkin L, Baird CJ, and Almeida OF (1985) Melatonin: a coordinating signal for mammalian reproduction? Science 227:714-720.

Tan DX, Manchester LC, Terron MP, Flores LJ, and Reiter RJ (2007) One molecule, many derivatives: a never-ending interaction of melatonin with reactive oxygen and nitrogen species? J Pineal Res 42:28-42.

Teh MT and Sugden D (1998) Comparison of the structure-activity relationships of melatonin receptor agonists and antagonists: lengthening the $\mathrm{N}$-acyl side-chain has differing effects on potency on Xenopus melanophores. Naunyn Schmiedebergs Arch Pharmacol 358:522-528.

Teh MT and Sugden D (1999) The putative melatonin receptor antagonist GR128107 is a partial agonist on Xenopus laevis melanophores. Br J Pharmacol 126:12371245 .

Tenn C and Niles LP (1993) Physiological regulation of melatonin receptors in rat suprachiasmatic nuclei: diurnal rhythmicity and effects of stress. Mol Cell Endocrinol 98:43-48.

Tetsuo M, Markey SP, and Kopin IJ (1980) Measurement of 6-hydroxymelatonin in human urine and its diurnal variations. Life Sci 27:105-109.

Ting KN, Dunn WR, Davies DJ, Sugden D, Delagrange P, Guardiola-Lemaître B, Scalbert E, and Wilson VG (1997) Studies on the vasoconstrictor action of melatonin and putative melatonin receptor ligands in the tail artery of juvenile Wistar rats. Br J Pharmacol 122:1299-1306.

Ting KN, Blaylock NA, Sugden D, Delagrange P, Scalbert E, and Wilson VG (1999) Molecular and pharmacological evidence for MT1 melatonin receptor subtype in the tail artery of juvenile Wistar rats. Br J Pharmacol 127:987-995.

Torres-Farfan C, Richter HG, Germain AM, Valenzuela GJ, Campino C, RojasGarcía P, Forcelledo ML, Torrealba F, and Serón-Ferré M (2004) Maternal melatonin selectively inhibits cortisol production in the primate fetal adrenal gland $J$ Physiol 554:841-856.

Torres-Farfan C, Richter HG, Rojas-García P, Vergara M, Forcelledo ML, Valladares LE, Torrealba F, Valenzuela GJ, and Serón-Ferré M (2003) mt1 Melatonin receptor in the primate adrenal gland: inhibition of adrenocorticotropin-stimulated cortisol production by melatonin. J Clin Endocrinol Metab 88:450-458.

Tosini G, Davidson AJ, Fukuhara C, Kasamatsu M, and Castanon-Cervantes O (2007) Localization of a circadian clock in mammalian photoreceptors. FASEB $J$ 21:3866-3871

Tosini G and Menaker M (1998) The clock in the mouse retina: melatonin synthesis and photoreceptor degeneration. Brain Res 789:221-228.

Tricoire H, Locatelli A, Chemineau P, and Malpaux B (2002) Melatonin enters the cerebrospinal fluid through the pineal recess. Endocrinology 143:84-90.

Vachharajani NN, Yeleswaram K, and Boulton DW (2003) Preclinical pharmacokinetics and metabolism of BMS-214778, a novel melatonin receptor agonist. J Pharm Sci 92:760-772.

Vakkuri O, Lämsä E, Rahkamaa E, Ruotsalainen H, and Leppäluoto J (1984) Iodinated melatonin: preparation and characterization of the molecular structure by mass and 1H NMR spectroscopy. Anal Biochem 142:284-289.

Vanecek J (1998) Cellular mechanisms of melatonin action. Physiol Rev 78:687-721.

Vanecek J and Klein DC (1992) Melatonin inhibits gonadotropin-releasing hormoneinduced elevation of intracellular $\mathrm{Ca} 2+$ in neonatal rat pituitary cells. Endocrinology 130:701-707.

Vanecek J and Klein DC (1995) Melatonin inhibition of GnRH-induced LH release from neonatal rat gonadotroph: involvement of $\mathrm{Ca}^{2+}$ not cAMP. Am J Physiol 269:E85-E90.

Vaněcek J, Pavlík A, and Illnerová H (1987) Hypothalamic melatonin receptor sites revealed by autoradiography. Brain Res 435:359-362.

Vanecek J and Vollrath L (1990) Developmental changes and daily rhythm in melatonin-induced inhibition of $3^{\prime}, 5^{\prime}$-cyclic AMP accumulation in the rat pituitary. Endocrinology 126:1509-1513.

Vanhoutte PM, Humphrey PP, and Spedding M (1996) X. International Union of Pharmacology recommendations for nomenclature of new receptor subtypes. Phar macol Rev 48:1-2.

Viani A, Rizzo G, Carrai M, and Pacifici GM (1992) The effect of aging on plasma albumin and plasma protein binding of diazepam, salicylic acid and digitoxin in healthy subjects and patients with renal impairment. Br J Clin Pharmacol 33: 299-304.

Viswanathan M, Laitinen JT, and Saavedra JM (1990) Expression of melatonin receptors in arteries involved in thermoregulation. Proc Natl Acad Sci USA 87: $6200-6203$.

Viswanathan M, Scalbert E, Delagrange P, Guardiola-Lemaître B, and Saavedra JM (1997) Melatonin receptors mediate contraction of a rat cerebral artery. Neuroreport 8:3847-3849.

von Gall C, Garabette ML, Kell CA, Frenzel S, Dehghani F, Schumm-Draeger PM Weaver DR, Korf HW, Hastings MH, and Stehle JH (2002a) Rhythmic gene expression in pituitary depends on heterologous sensitization by the neurohormone melatonin. Nat Neurosci 5:234-238.

von Gall C, Weaver DR, Kock M, Korf HW, and Stehle JH (2000) Melatonin limits transcriptional impact of phosphoCREB in the mouse SCN via the Mel1a receptor. Neuroreport 11:1803-1807.

Waldhauser F, Waldhauser M, Lieberman HR, Deng MH, Lynch HJ, and Wurtman RJ (1984) Bioavailability of oral melatonin in humans. Neuroendocrinology 39: 307-313.
Waldhauser F, Weiszenbacher G, Tatzer E, Gisinger B, Waldhauser M, Schemper M, and Frisch H (1988) Alterations in nocturnal serum melatonin levels in humans with growth and aging. $J$ Clin Endocrinol Metab 66:648-652.

Wallez V, Durieux-Poissonnier S, Chavatte P, Boutin JA, Audinot V, Nicolas JP, Bennejean C, Delagrange P, Renard P, and Lesieur D (2002) Synthesis and structure-affinity-activity relationships of novel benzofuran derivatives as MT(2) melatonin receptor selective ligands. J Med Chem 45:2788-2800.

Wang LM, Suthana NA, Chaudhury D, Weaver DR, and Colwell CS (2005) Melatonin inhibits hippocampal long-term potentiation. Eur $J$ Neurosci 22:2231-2237.

Weaver DR, Liu C, and Reppert SM (1996) Nature's knockout: the Mel1b receptor is not necessary for reproductive and circadian responses to melatonin in Siberian hamsters. Mol Endocrinol 10:1478-1487.

Weaver DR and Reppert SM (1996) The Mel1a melatonin receptor gene is expressed in human suprachiasmatic nuclei. Neuroreport 8:109-112.

Weibel L, Rettori MC, Lesieur D, Delagrange P, Renard P, and Van Reeth O (1999) A single oral dose of S 22153, a melatonin antagonist, blocks the phase advancing effects of melatonin in C3H mice. Brain Res 829:160-166.

Weil ZM, Hotchkiss AK, Gatien ML, Pieke-Dahl S, and Nelson RJ (2006) Melatonin receptor (MT1) knockout mice display depression-like behaviors and deficits in sensorimotor gating. Brain Res Bull 68:425-429.

Weitzman ED, Fukushima D, Nogeire C, Roffwarg H, Gallagher TF, and Hellman L (1971) Twenty-four hour pattern of the episodic secretion of cortisol in normal subjects. J Clin Endocrinol Metab 33:14-22

White BH, Sekura RD, and Rollag MD (1987) Pertussis toxin blocks melatonin induced pigment aggregation in Xenopus dermal melanophores. J Comp Physiol B 157:153-159.

Witt-Enderby PA and Dubocovich ML (1996) Characterization and regulation of the human ML1A melatonin receptor stably expressed in Chinese hamster ovary cells Mol Pharmacol 50:166-174.

Witt-Enderby PA, MacKenzie RS, McKeon RM, Carroll EA, Bordt SL, and Melan MA (2000) Melatonin induction of filamentous structures in non-neuronal cells that is dependent on expression of the human mt1 melatonin receptor. Cell Motil Cy. toskeleton 46:28-42.

Witt-Enderby PA, Masana MI, and Dubocovich ML (1998) Physiological exposure to melatonin supersensitizes the cyclic adenosine $3^{\prime}, 5^{\prime}$-monophosphate-dependent signal transduction cascade in Chinese hamster ovary cells expressing the human mt1 melatonin receptor. Endocrinology 139:3064-3071.

Woo MM, Tai CJ, Kang SK, Nathwani PS, Pang SF, and Leung PC (2001) Direct action of melatonin in human granulosa-luteal cells. J Clin Endocrinol Metab 86:4789-4797.

Wu YH, Zhou JN, Van Heerikhuize J, Jockers R, and Swaab DF (2007) Decreased MT1 melatonin receptor expression in the suprachiasmatic nucleus in aging and Alzheimer's disease. Neurobiol Aging 28:1239-1247.

Wurtman R (2006) Ramelteon: a novel treatment for the treatment of insomnia. Expert Rev Neurother 6:957-964.

Wurtman RJ and Axelrod J (1968) The formation, metabolism and physiologic effects of melatonin. Adv Pharmacol 6:141-151.

Xi SC, Siu SW, Fong SW, and Shiu SY (2001) Inhibition of androgen-sensitive LNCaP prostate cancer growth in vivo by melatonin: association of antiproliferative action of the pineal hormone with mt1 receptor protein expression. Prostate 46:52-61.

Yasuo S, Yoshimura T, Ebihara S, and Korf HW (2009) Melatonin transmits photoperiodic signals through the MT1 melatonin receptor. J Neurosci 29:2885-2889.

Ying SW, Niles L, Pickering D, and Ye M (1992) Involvement of multiple sulfhydryl groups in melatonin signal transduction in chick brain. Mol Cell Endocrinol 85:53-63.

Ying SW, Rusak B, Delagrange P, Mocaer E, Renard P, and Guardiola-Lemaitre B (1996) Melatonin analogues as agonists and antagonists in the circadian system and other brain areas. Eur J Pharmacol 296:33-42.

Young IM, Leone RM, Francis P, Stovell P, and Silman RE (1985) Melatonin is metabolized to N-acetyl serotonin and 6-hydroxymelatonin in man. $J$ Clin Endocrinol Metab 60:114-119.

Yous S, Durieux-Poissonnier S, Lipka-Belloli E, Guelzim H, Bochu C, Audinot V Boutin JA, Delagrange P, Bennejean C, Renard P, et al. (2003) Design and synthesis of 3-phenyl tetrahydronaphthalenic derivatives as new selective MT2 melatoninergic ligands. Bioorg Med Chem 11:753-759.

Yuan L, Collins AR, Dai J, Dubocovich ML, and Hill SM (2002) MT(1) melatonin receptor overexpression enhances the growth suppressive effect of melatonin in human breast cancer cells. Mol Cell Endocrinol 192:147-156.

Yukuhiro N, Kimura H, Nishikawa H, Ohkawa S, Yoshikubo S, and Miyamoto M (2004) Effects of ramelteon (TAK-375) on nocturnal sleep in freely moving monkeys. Brain Res 1027:59-66.

Zalatan F, Krause JA, and Blask DE (2001) Inhibition of isoproterenol-induced lipolysis in rat inguinal adipocytes in vitro by physiological melatonin via a receptor-mediated mechanism. Endocrinology 142:3783-3790.

Zemlan FP, Mulchahey JJ, Scharf MB, Mayleben DW, Rosenberg R, and Lankford A (2005) The efficacy and safety of the melatonin agonist beta-methyl-6chloromelatonin in primary insomnia: a randomized, placebo-controlled, crossover clinical trial. J Clin Psychiatry 66:384-390.

Zeng FY, Soldner A, Schöneberg T, and Wess J (1999) Conserved extracellular cysteine pair in the M3 muscarinic acetylcholine receptor is essential for proper receptor cell surface localization but not for $\mathrm{G}$ protein coupling. $J$ Neurochem 72:2404-2414 